UNIVERSIDADE DE SÃO PAULO

FACULDADE DE FILOSOFIA, LETRAS E CIÊNCIAS HUMANAS

DEPARTAMENTO DE SOCIOLOGIA

PROGRAMA DE PÓS-GRADUAÇÃO EM SOCIOLOGIA

Danilo Sales do Nascimento França

danilo.franca@usp.br

\title{
Raça, Classe e Segregação Residencial no Município de São Paulo
}


Danilo Sales do Nascimento França

\section{Raça, Classe e Segregação Residencial no Município de São Paulo}

Dissertação apresentada ao Programa de Pós-Graduação em Sociologia da Faculdade de Filosofia, Letras e Ciências Humanas da Universidade de São Paulo como requisito para a obtenção do título de Mestre em Sociologia.

Orientadora: Profa. Dra. Márcia Regina de Lima Silva

São Paulo

2010 
Nome: FRANÇA, Danilo Sales do Nascimento

Título: Raça, Classe e Segregação Residencial no Município de São Paulo

Dissertação apresentada ao Programa de

Pós-Graduação em Sociologia da

Faculdade de Filosofia, Letras e Ciências

Humanas da Universidade de São Paulo

como requisito para a obtenção do título de Mestre em Sociologia.

Aprovado em:

Banca Examinadora

Instituição:

Julgamento: Assinatura:

Instituição:

Julgamento: Assinatura:

Instituição:

Julgamento: Assinatura: 
Dedicatória

À memória do meu avô Miguel Santos do Nascimento, que, quando vivo,costumava dizer: "Deus me dê saúde pra poder ver meu preto formado."

E à minha família. 


\section{Agradecimentos}

Agradeço a Capes (Coordenadoria de Aperfeiçoamento de Pessoal de Nível Superior) e ao CNPq (Conselho Nacional de Desenvolvimento Científico e Tecnológico) pela concessão das bolsas que possibilitaram a realização deste trabalho.

Aos funcionários da Faculdade de Filosofia, Letras e Ciências Humanas (FFLCH) da USP, especialmente aqueles que trabalham no Departamento de Sociologia.

Agradeço também o apoio que obtive no Centro de Estudos da Metrópole (CEM) do Centro Brasileiro de Análise e Planejamento (CEBRAP). Ao professor Eduardo Marques, por me fornecer o banco de dados com as ocupações recodificadas segundo as categorias EGP.

Foram de grande importância no período de redação final desta dissertação o apoio e a compreensão por parte da Associação Amigos do Projeto Guri (AAPG), Organização Social de Cultura da qual sou empregado. Ressalto o papel de Daniel Ribeiro, gestor da equipe da qual faço parte, que fez tudo o que esteve ao seu alcance para que eu tivesse tranqüilidade para me dedicar à conclusão deste mestrado.

Agradeço à minha orientadora, Márcia Lima por ter acreditado em mim e no meu projeto de pesquisa, incentivando a realização deste e o meu desenvolvimento como sociólogo. Tive a honra e a sorte de ser o seu primeiro orientando de pósgraduação. Sou o primeiro de muitos que receberão dela uma orientação atenciosa, compreensiva e camarada, como foi a que eu tive. Tenho grandes esperanças de que nossa parceria continuará rendendo bons frutos.

Haroldo Torres e Antonio Sérgio Guimarães compuseram uma ótima banca de qualificação, dando sugestões valiosas e transmitindo a segurança de que a minha pesquisa estava caminhando numa direção correta. O professor Antonio Sérgio contribuiu bastante com a minha formação, seja através da disciplina de Sociologia das Relações Raciais, seja através das reuniões do grupo de estudos.

No Programa de Pós-Graduação em Sociologia tive a honra de ser colega de jovens e brilhantes sociólogos que, além de me serviram de exemplo, também deram grandes contribuições para o meu trabalho. Gostaria de citar alguns que são também grandes amigos: Flávia Mateus Rios, Bruna Gisi (que junto com o Paulo Scarpa fez o 
Abstract aos 45 do segundo tempo), Rogério Jerônimo Barbosa, Matheus Gato de Jesus, Edilza Sotero e Jonas Bicev. Flávia foi uma das primeiras pessoas que me incentivaram a participar do processo seletivo para o mestrado. Rogério foi um amigo com o qual eu sempre pude contar. Com grande disposição em ajudar e em transmitir seus conhecimentos, ele me ensinou muito do que sei sobre métodos quantitativos, incentivou minha participação no MQ (Curso Intensivo de Metodologia Quantitativa da UFMG) e deu contribuições importantes para este trabalho.

Para evitar o risco de cometer injustiças, não tentarei citar nominalmente cada um dos muitos amigos e pessoas queridas que conheci e convivi neste período do mestrado, e que me proporcionaram várias alegrias, me acolheram nos momentos de insegurança e ajudaram a tornar minha vida mais suave nesta fase que, algumas vezes, foi muito dura.

Durante a maior parte deste período de mestrado minha vida se enriqueceu com a companhia, apoio, carinho, compreensão e paciência de Larissa, companheira preciosa.

Agradeço à minha família, em especial meus pais Messias e Cida, que criaram todas as condições para minha trajetória, apoiaram as minhas escolhas e me transmitiram a serenidade com a qual procuro encarar a vida. Meu irmão Vinícius é um dos meus maiores parceiros, com quem tenho sempre conversas instigantes e momentos felizes. A ele agradeço também pela leitura de partes desta dissertação. 


\section{Resumo}

\section{Raça, Classe e Segregação Residencial no Município de São Paulo.}

Esta dissertação de mestrado desenvolve uma análise da segregação residencial no município de São Paulo, descrita a partir da articulação entre raça e classe social. Deste modo, realçamos as diferenças de padrões residenciais de negros e brancos pertencentes a estratos sociais semelhantes, dando ênfase à caracterização da segregação racial nas classes médias e altas de São Paulo. A partir desta descrição, revelamos a maneira pela qual a segregação se relaciona com o perfil da estratificação social e das desigualdades raciais no Brasil, refletindo as dificuldades de inserção dos negros em estratos sociais mais altos.

Para tanto, defendemos a hipótese de que a distância residencial entre os negros e brancos aumenta conforme consideramos as camadas sociais médias e altas. De modo que os negros destes estratos apresentam maior concentração em bairros mais pobres e periféricos. Esta hipótese é demonstrada através de uma ampla análise quantitativa, na qual exploramos a aplicação de diversas técnicas disponíveis para mensuração e análise da segregação residencial.

Nossa argumentação acerca destas questões se alicerça no campo da sociologia das relações raciais, em diálogo com a produção brasileira e norte-americana sobre segregação residencial.

Palavras-chave: segregação residencial, relações raciais, estratificação social, classe média negra. 


\section{Abstract}

\section{Race, Class and Residential Segregation in São Paulo}

In this dissertation we develop an analysis of residential segregation in the city of São Paulo based upon the articulation of race and social class. In this way one can stress the differences in residential patterns among blacks and whites belonging to similar social strata, highlighting racial segregation in middle and upper classes in São Paulo. From this description we reveal the way in which segregation relates itself with the contour of social stratification and racial inequalities in Brazil, reflecting on the difficulties in inclusion of blacks in higher social strata.

For such, we defend the hypothesis that the residential distance in blacks and whites increases as we look upon the middle and higher social classes. The blacks in these strata are more concentrated in poorer and peripheral neighborhoods. This hypothesis is demonstrated through a wide quantitative analysis in which we apply several available techniques for measurement and analysis of residential segregation.

Our argument for such questions is based on the sociology of racial relations, but also in dialogue with the north-American and Brazilian literature relating to residential segregation.

Keyworkds: residential segregation, racial relations, social stratification, black middle class. 


\section{Sumário}

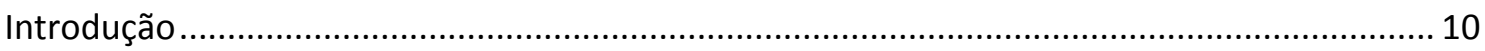

Capítulo 1 - Estratificação social, raça e espaço ........................................................................ 19

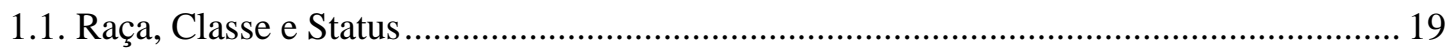

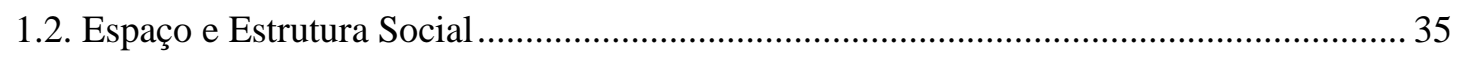

Capítulo 2 - Segregação Residencial e Raça no Brasil e nos Estados Unidos ............................... 47

2.1. Segregação: conceitos, medidas e dimensões .................................................................... 47

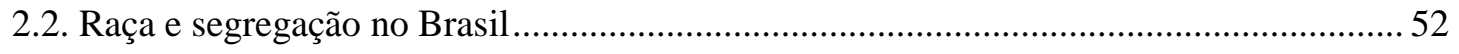

2.3. Segregação Residencial na Abordagem norte-americana ................................................ 58

Capítulo 3 - Mensuração da Segregação Residencial no Município de São Paulo ........................66

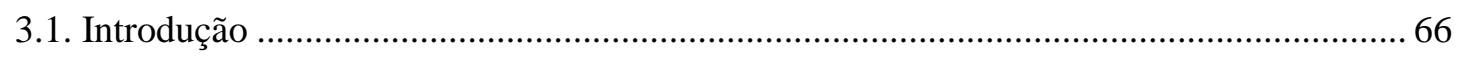

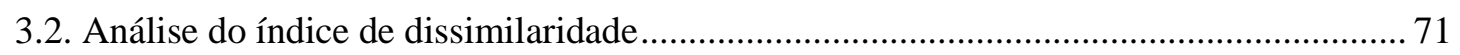

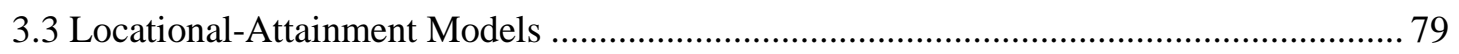

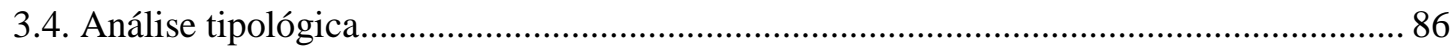

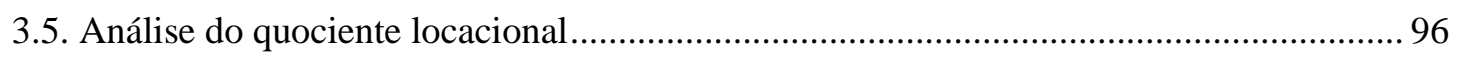

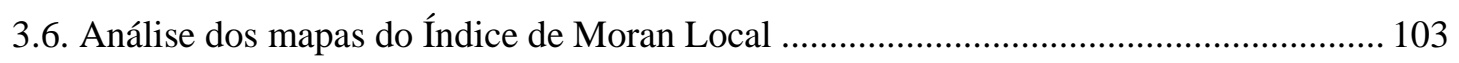

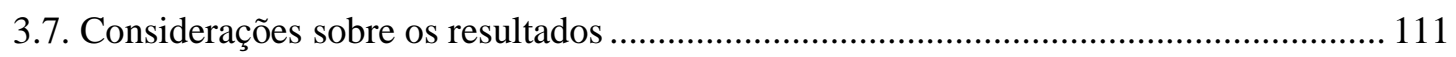

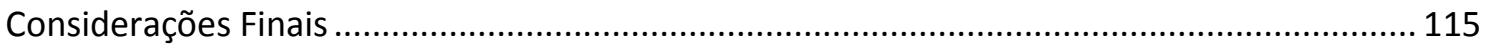

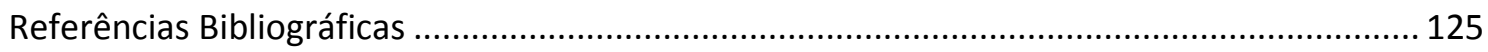




\section{Introdução}

Esta dissertação de mestrado desenvolve uma análise da segregação residencial ${ }^{1}$ no município de São Paulo, descrita a partir da articulação entre raça ${ }^{2}$ e classe social ${ }^{3}$, tendo em vista questões acerca da inserção dos negros nas classes médias e altas. Mais especificamente, desejamos descrever a segregação residencial, não apenas através de linhas de classe, tampouco apenas através de linhas raciais, mas sim realçando as diferenças de padrões residenciais entre negros e brancos pertencentes a estratos sociais semelhantes. Todavia, daremos ênfase à caracterização da segregação racial nas camadas médias e altas de São Paulo. A partir desta descrição, revelamos em que medida a segregação se relaciona com o perfil da estratificação social e das desigualdades entre negros e brancos no Brasil.

Para abordar as questões propostas, partimos do campo da sociologia das relações raciais, e realizamos um diálogo com estudos sobre segregação espacial, com estudos sobre o tema da classe média negra e também com aqueles que articulam a temática racial com espaço urbano.

O estudo da segregação residencial, e mais especificamente da segregação racial, é um tema clássico na sociologia norte-americana. A concentração dos negros, de alguns grupos étnicos e de imigrantes em bairros específicos é uma característica marcante das metrópoles dos Estados Unidos, despertando grande interesse desde o início do século XX. A segregação entre negros e brancos é um tópico constante nas

\footnotetext{
${ }^{1}$ Previamente, definiremos segregação residencial como o grau em que os grupos sociais encontram-se distantes uns dos outros, considerando a localização de seus locais de moradia no espaço urbano. Aprofundaremos a discussão sobre o conceito de segregação no capítulo 2 desta dissertação.

2 Este trabalho trata das relações raciais entre brancos e negros. Sendo este último grupo racial operacionalizado a partir da soma das categorias de cor da pele pretos e pardos, aplicadas no Censo pelo IBGE (Instituto Brasileiro de Geografia e Estatística). "Cor" é entendida aqui como uma categoria racial, tal qual nos ensina Guimarães (2003: 103-4): “(...) a análise dessa categoria, no Brasil, nos leva à conclusão, sem grande dificuldade, de que a classificação por cor é orientada pela idéia de raça, ou seja, que a classificação das pessoas por cor é orientada por um discurso sobre qualidades, atitudes e essências transmitidas por sangue, que remontam a uma origem ancestral comum (...) O meu argumento é o seguinte: "cor" não é uma categoria objetiva, cor é uma categoria racial, pois quando se classificam as pessoas como negros, mulatos ou pardos é a idéia de raça que orienta essa forma de classificação."

${ }^{3}$ Trabalharemos com definições operacionais de classes sociais, diferenciadas por intermédio de faixas de renda. Assim, quando falamos em negros de classe média, por exemplo, nos referimos aos negros que possuem uma renda domiciliar acima de um limite determinado. Apresentaremos maiores detalhes sobre esta operacionalização no capítulo 3.
} 
pesquisas sociológicas neste país, sendo considerada por muitos autores um dos principais eixos organizadores das relações raciais dos Estados Unidos.

No Brasil, o estudo da segregação residencial nas metrópoles foi pautado pelo modelo de oposição entre centro rico e periferia pobre, e suas conseqüências para a reprodução das desigualdades de classe. Como herança deste modelo, até hoje a segregação no Brasil é analisada predominantemente através em linhas de classe. Existem, de fato, algumas pesquisas que descrevem os padrões de segregação enfocando a variável raça. Entretanto, estas últimas são exceções.

De modo geral, propaga-se uma ideia, que não se restringe ao senso comum, de que os padrões habitacionais nas metrópoles brasileiras organizam-se, basicamente (senão unicamente), a partir das desigualdades de classe social (Cf., por exemplo, Villaça 2004) e que "as diferenças raciais no campo habitacional existiam apenas na medida em que eram coincidentes com as diferenças de classe" (Telles 2003: 161).

Estudos seminais da sociologia das relações raciais brasileiras (Pierson (1971 [1942]), Costa Pinto (1998 [1953]), Cardoso e Ianni (1960)) apontaram que a segregação por raça não seria uma característica importante, estando fortemente condicionada pela classe social. E desde então, a segregação foi uma questão muito pouco abordada neste campo de pesquisas.

$\mathrm{Na}$ década de 1990, esta discussão sobre segregação residencial foi reintroduzida no quadro das relações raciais brasileiras pelo sociólogo norte-americano Edward Telles. Ele aponta que, de fato, o histórico de segregação no Brasil tem grandes diferenças do norte-americano, além de apresentar-se em níveis mais moderados. No entanto, "O fato de a segregação não ocorrer no Brasil com os mesmos níveis elevados dos Estados Unidos ou da África do Sul não significa que a raça seja uma categoria insignificante para a análise das questões urbanas do país. São várias as razões que justificam o exame do caso brasileiro, principalmente o fato de que talvez exista mais segregação residencial no Brasil do que imaginam muitos brasileiros." (Telles 2003: 162).

O trabalho de Edward Telles fornece os pontos de partida, empíricos e teóricos, desta dissertação. Os primeiros residem nos artigos em que Telles $(1993,1995,1996)$ apresenta evidências empíricas da segregação no Brasil, mostrando que os índices de segregação cresciam conforme se levava em conta os negros e brancos nos estratos 
sociais médios e altos. Se os índices de segregação residencial por raça crescem com a classe social, isso indica que a influência da raça é mais forte nos estratos mais altos.

Esta é uma das argumentações desenvolvidas por este autor no livro Racismo à Brasileira (2003), no qual constrói um modelo de análise das relações raciais que servirá como uma das nossas principais referências.

Neste livro, Edward Telles constrói uma síntese da produção sobre as relações raciais no Brasil até aquele momento. A partir da análise desta bibliografia, somada a evidências empíricas quantitativas (provindas de dados censitários e de pesquisas amostrais nacionais), o autor propõe "uma nova perspectiva sociológica" sobre o sistema racial brasileiro. De acordo com essa perspectiva, para dar conta da complexidade das relações raciais no Brasil, deveremos concebê-las segundo duas dimensões, a das relações verticais e a das relações horizontais, sobre as quais trataremos logo abaixo.

O questionamento que atua como mote do trabalho de Telles gira em torno da coexistência de dois traços aparentemente contraditórios no sistema racial brasileiro: exclusão e mistura racial. Se, por um lado, o Brasil celebra a mestiçagem em sua ideologia de nação harmônica e livre de divisões raciais. Por outro lado, as diferenças raciais estão longe de serem irrelevantes, uma vez que o país é marcado por desigualdades entre brancos e negros que são atribuídas, em grande medida, à discriminação racial. A pergunta que guia as reflexões expostas no livro seria: Como é possível discriminação e fortes desigualdades raciais em um país onde não há segregação ou tensão racial, onde há grande mistura entre brancos e negros?

Telles divide a história dos estudos sobre o tema em duas gerações, cada uma delas enfatiza uma entre as duas facetas (mistura ou exclusão). A primeira geração, cujo principal expoente é Gilberto Freyre, defendeu, a partir da década de 1930, o papel da miscigenação como geradora de fluidez nas diferenças raciais e de proximidade entre negros e brancos nas relações cotidianas. A discriminação era considerada moderada e pouco relevante, e a desigualdade racial seria apenas um produto da escravidão, condicionado pela classe social, que desapareceria em pouco tempo.

Essa visão foi contestada a partir do final da década de 1950 pela segunda geração, liderada por Florestan Fernandes, que denunciava o racismo disseminado pela sociedade brasileira e a exclusão da população negra. Embora Fernandes acreditasse que o racismo desapareceria porque não era funcional para o desenvolvimento do 
capitalismo, em 1979, Carlos Hasenbalg constatou a manutenção das desigualdades entre negros e brancos e concluiu que o racismo era sim compatível com o capitalismo. As teorias desta segunda geração dominavam o consenso acadêmico quando da publicação de Racismo à Brasileira.

Segundo o Telles, as diferentes conclusões das duas gerações de estudos se devem ao fato de que cada uma delas enfatizou distintas dimensões da vida social, às quais o autor denominou como relações horizontais e relações verticais. Com base na distinção entre estas duas dimensões, o autor elabora um novo modelo para interpretação do sistema brasileiro de relações raciais.

As relações horizontais, mais evidenciadas pela primeira geração, tratam-se das interações cotidianas e de relações de sociabilidade, principalmente entre membros de uma mesma classe social, que as pesquisas demonstraram ser marcadas por maior suavidade. As relações verticais, às quais a segunda geração deu mais ênfase, são relações hierárquicas, entre membros de distintas classes sociais, que envolvem maiores graus de discriminação racial, e que resultam nas desigualdades entre negros e brancos.

Para o autor, o estudo das relações raciais brasileiras não pode furtar-se em considerar estas duas perspectivas. Deste modo, objetivo de seu trabalho é reexaminar os argumentos das duas gerações e, a partir delas, construir uma perspectiva integrada das relações raciais no Brasil, "partindo da premissa de que pode existir, ainda que de maneira limitada, alguma forma tanto de exclusão quanto de inclusão.” (p. 25). Paralelamente o autor empreende uma comparação com os Estados Unidos, dado que a raça é um princípio organizacional em ambas as sociedades, embora operando de distintas formas em cada uma delas.

Com relação às desigualdades verticais, ou sócio-econômicas, entre negros e brancos no Brasil, Telles argumenta que sua reprodução estaria baseada em três fatores causais principais. Primeiro, a hiper-desigualdade social, caracterizada pela extrema concentração de renda nas camadas mais ricas da população e pela grande proporção de pobres no país. Esta desigualdade tende a se reproduzir na medida em que está associada a fortes desigualdades educacionais, de poder e aos diferenciais de acesso ao capital social e a direitos civis e sociais. Na medida em que a pobreza afeta muito mais a população negra, as tendências de reprodução das desigualdades sociais apontam para a persistência das desigualdades entre brancos e negros. 
O segundo fator seria um sistema informal de "barreiras discriminatórias invisíveis" que fazem com que a ascensão social seja mais difícil para os negros do que para os brancos. Para Telles a principal clivagem social no Brasil seria entre a classe média branca e a classe pobre multirracial, mas principalmente negra. Esta classe média tira proveito de sua própria posição social e do fato das características fenotípicas (raciais) de negros e brancos serem desigualmente valoradas para reduzir a competição por status. E, na medida em que as distinções entre os grupos raciais são menos ambíguas para a classe média, os poucos negros de classe média sofrem grande discriminação, a ponto de não poder usufruir de diversos benefícios de sua posição.

\footnotetext{
“A raça é um fator marcante para a exclusão social, criando uma estrutura de classes na qual os negros são mantidos nos níveis mais baixos. A classe e a raça se tornam, então, conscientemente, determinantes de status na sociedade. Hierarquias raciais ou de classe são codificadas em regras informais de interação social e são consideradas naturais. Nelas, o status de uma pessoa ou sua posição na hierarquia garantem maiores direitos e privilégios." (Telles 2003: 309).
}

Por fim, o terceiro fator causal da reprodução das desigualdades raciais seria a cultura racista, que se refere a um conjunto de crenças e representações de que as posições subordinadas devem ser ocupadas por negros e aquelas que envolvem controle de recursos por brancos. A mídia e a cultura popular - incluindo uma série de insultos, piadas e ditados racistas - legitimam esta cultura, levando à baixa auto-estima dos negros e à internalização e naturalização desta hierarquia pelos membros da sociedade como um todo.

Por outro lado, estas desigualdades verticais entre negros e brancos coexiste com mistura e proximidade nas relações horizontais, de intimidade e interações cotidianas.

De acordo com o autor, esta coexistência desafia diversas teorias norteamericanas que pressupõem que as relações horizontais seriam indicadores de adaptabilidade, integração e assimilação dos grupos minoritários. Além disso, consideram também que as relações verticais seriam conseqüência das horizontais. Ou seja, o preconceito e a discriminação, que ocasionam as desigualdades raciais, seriam sustentados pela "distância social” entre negros e brancos nas relações horizontais. Assim, segundo esta concepção, sendo harmônicas as relações horizontais brasileiras, no futuro não deveria haver qualquer hierarquia, conflito ou exploração racial. 
Para abordar as relações horizontais, mais especificamente as características de miscigenação e sociabilidade entre negros e brancos brasileiros, Telles recorre à análise de dois indicadores de "distância racial" utilizados na sociologia norte-americana: a segregação residencial e o casamento inter-racial. ${ }^{4}$

Os casamentos e relacionamentos afetivos inter-raciais seriam a mais forte expressão da proximidade entre negros e brancos, permitindo revelar em que medida a ideologia da miscigenação se fundamenta na realidade empírica.

Nesse sentido, Telles nota uma grande frequiência de casamentos inter-raciais, evidenciando que a mistura racial ocorre nas esferas íntimas muito mais do que nos Estados Unidos. Entretanto, mesmo nestas esferas afetivas, a hierarquia não desaparece, de modo que os brancos prevalecem em uma posição de vantagem nas relações entre os casais e no mercado do namoro.

A análise da segregação residencial baseia-se em medidas que revelam o quão próximas ou distantes estão as moradias de diferentes grupos sociais nos espaços das cidades. Ou seja, a partir da distância física residencial no espaço urbano, o estudo da segregação visa apreender esta idéia mais geral de "distância social” entre os grupos ou, mais concretamente, as possibilidades de exposição e contato de um grupo com o outro.

Os primeiros estudos norte-americanos sobre segregação fazem referência à existência de contextos de vizinhança que favoreçam ou dificultem a sociabilidade entre os grupos étnicos e raciais. A proximidade física dos lares e o compartilhamento de locais de convívio fazem com que a vizinhança seja considerada uma importante esfera de interação face-a-face, agregando indivíduos, em geral, socialmente semelhantes. (Cf Massey 1981, Logan 1978, Charles 2003, Telles 2003).

Ademais, diversos estudos apontam a importância da segregação em sua relação com diversos outros elementos: possibilidades de acesso ao mercado de trabalho, realização educacional, sócio-econômica e, por conseguinte, reprodução de desigualdades; exposição à violência e à criminalidade; cristalização de estigmas e estereótipos; constituição de redes sociais, identidades e de solidariedades intra-grupais;

\footnotetext{
${ }^{4}$ Segundo o Telles: "Ao limitar suas análises à dimensão horizontal da sociabilidade, a primeira geração concluiu que as relações raciais eram bem melhores no Brasil do que nos Estados Unidos. Níveis de união inter-racial e segregação residencial eram indicadores importantes sobre até que ponto os negros eram aceitos ou assimilados pelos brancos. Acadêmicos daquela época acreditavam que as desigualdades raciais no Brasil eram temporárias, uma vez que não constataram, no país, o racismo gritante e a profunda distância racial encontrada nos Estados Unidos.” (Telles 2003: 303)
} 
além de representações sociais sobre as desigualdades sociais e sobre o próprio espaço urbano. 5

Nos Estados Unidos, a forte segregação residencial é considerada um fator crucial que contribui para a organização das relações interpessoais entre negros e brancos e, também, para a manutenção das desigualdades raciais.

Ao analisar os dados de segregação residencial das cidades brasileiras e seu papel nas relações raciais do Brasil, Edward Telles descobriu que por aqui a segregação é bastante moderada, se comparada aos exemplos extremos dos Estados Unidos. Não obstante, devemos encarar como sendo significativo o fato de que haja graus (mesmo que moderados) de segregação, num lugar onde anteriormente se considerava esta uma dimensão sem relevância.

Além disso, de acordo com os indicadores de segregação apurados por Telles (1993, 1995, 1996, 2003), há grande proximidade entre negros e brancos nas classes baixas e distância nas classes altas. Isso é interpretado como um indicador de que a sociabilidade inter-racial não se distribui de modo homogêneo pelas classes sociais. De acordo este autor:

\footnotetext{
"Embora a interação de fato entre brancos e negros nas áreas urbanas do Brasil seja freqüentemente limitada a estes bairros [pobres], o fato de haver proximidade física significa que os grupos raciais possuem maior probabilidade de ter uma cultura comum e desenvolver amizades inter-raciais. Isso (...) permite que a proximidade residencial seja tanto causa como conseqüência da socialização inter-racial. A residência reforça a socialização inter-racial dentro de uma mesma classe no Brasil a um grau maior do que nos Estados Unidos.

(...) Tal interação, no entanto, é geralmente limitada aos bairros pobres do Brasil, em quase todas as regiões, e ocorre principalmente em situações em que os brancos pobres são minoria e os pretos e pardos são maioria. Os brancos da classe média brasileira possuem poucos vizinhos negros, salvo talvez na condição de serviçais, principalmente porque estes têm sido mantidos fora desta classe.” (Telles 2003: 182-3).
}

Tais análises demonstram a relevância do estudo da segregação residencial nas cidades brasileiras para a caracterização das relações raciais no nosso país. Isso não implica, evidentemente, que devemos considerar a segregação no Brasil da mesma

\footnotetext{
${ }^{5}$ São muitos os estudos que tratam destas temáticas. Podemos citar, por exemplo, Telles 1995, 1996; Caldeira 2000; Torres 2004a; Qadeer 2004; Sabatini et al. 2004; os artigos da coletânea de Marques e Torres 2005; Flores 2006; Bichir 2006; dentre vários outros.
} 
forma que a dos Estados Unidos. ${ }^{6}$ Além das diferenças de contexto histórico e das diferenças de grau, nos Estados Unidos a segregação tem um forte papel na organização das relações entre brancos e negros em geral, gerando implicações mais prejudiciais aos negros de camadas mais baixas. Aqui, ela revela a maior distância entre negros e brancos de classes sociais mais elevadas, que se relaciona com o segundo fator de reprodução das desigualdades raciais apontado por Telles: as "barreiras invisíveis à ascensão" dos negros.

Assim, ao direcionar nossa atenção para as variações de graus de segregação segundo as distintas classes sociais, consideraremos a segregação residencial, que a princípio seria uma dimensão das relações horizontais, vinculada com a dimensão vertical das desigualdades. Deste modo, o estudo da segregação residencial pode ser uma via profícua para revelar as articulações entre raça e classe na sociedade brasileira e as dificuldades de inserção dos negros nas camadas médias e altas.

Nesse sentido, esta pesquisa busca ratificar a assertiva de que a distância residencial entre os negros e brancos aumenta conforme consideramos as camadas sociais médias e altas. De modo que os negros destes estratos apresentam maior concentração em bairros mais pobres e periféricos de São Paulo.

Perseguiremos estas hipóteses através de uma ampla análise quantitativa, na qual exploraremos a aplicação das diversas técnicas disponíveis para mensuração e análise da segregação residencial. Para tanto, lançaremos mão dos dados da Amostra do Censo de 2000 para o município de São Paulo.

No capítulo 1, a seguir, chamado "Estratificação social, raça e espaço", iniciamos utilizando o conceito de status de Max Weber para debater com as pesquisas da sociologia das relações raciais que tratam da inserção dos negros nas hierarquias sociais brasileiras. E terminamos apresentando o marco teórico de Pierre Bourdieu para tratar das relações entre espaço e estrutura social, dialogando com pesquisas sobre este tema realizadas em metrópoles brasileiras.

\footnotetext{
${ }^{6}$ Segundo o próprio Telles: "O fato de a segregação não ocorrer no Brasil com os mesmos níveis elevados dos Estados Unidos ou da África do Sul não significa que a raça seja uma categoria insignificante para a análise das questões urbanas do país. (...) a segregação racial no Brasil não é autoevidente e requer uma mensuração sistemática. Além disso, as interpretações dos índices de segregação devem ser entendidas como um reflexo da história, não implicando pressupostos inerentes aos sistemas de segregação baseados na lei, como nos Estados Unidos e na África do Sul, nem tampouco abraçando a ideologia da democracia racial, que ofusca o entendimento de como operam raça e classe no Brasil." (Telles 2003: 162-3).
} 
O segundo capítulo realiza uma discussão sobre o conceito de segregação, apresentando pesquisas brasileiras sobre o tema, especialmente aquelas que introduzem a variável raça nas discussões sobre questões urbanas. Além disso, considerando o grande acúmulo da produção sociológica norte-americana acerca da segregação racial, tratamos das características deste fenômeno nos Estados Unidos e discutimos algumas abordagens teóricas sobre estas questões em voga neste país.

O capítulo 3 apresenta a análise quantitativa empreendida. Aplicamos distintas técnicas de mensuração de segregação disponíveis. De maneira que as conclusões resultantes de cada uma possam ser corroboradas ou contrastadas pelas outros. Deste modo, buscamos revelar os alcances e limitações das diferentes técnicas, bem como um maior número de facetas da segregação em São Paulo, aumentando, assim, nossa capacidade descritiva.

No capítulo conclusivo, retomamos as principais descobertas e argumentos desta pesquisa e apresentamos questões que emergem a partir dela.

Esse estudo, além de ter como referencial metodológico pesquisas vinculadas ao Centro de Estudos da Metrópole do Centro Brasileiro de Análise e Planejamento (CEMCEBRAP), está ligado ao módulo "As dinâmicas de cor e classe em contextos metropolitanos" da linha de pesquisa "Mercado, trabalho e oportunidades", do CEM. Esta linha de pesquisa tem o intuito de contribuir e dialogar diretamente com as pesquisas que têm sido produzidas no âmbito desta instituição, introduzindo a temática racial.

Tais pesquisas têm colaborado para a evolução e renovação do debate brasileiro sobre segregação nas metrópoles, aproveitando a maior disponibilidade de dados quantitativos e introduzindo novas técnicas de análise e da mensuração da segregação residencial. Além disso, estes estudos enfatizam a importância do espaço como elemento condicionante das oportunidades e possibilidades de vida das pessoas, interferindo na reprodução das desigualdades. 


\section{Capítulo 1 - Estratificação social, raça e espaço}

Este capítulo busca realizar uma articulação entre as noções de raça, classe e espaço, com o objetivo de reunir argumentos teóricos (sustentados por experiências empíricas) que balizem nossa interpretação do objeto de estudo desta pesquisa: a segregação residencial entre negros e brancos em estratos sociais médios e altos.

A primeira parte dialoga com a literatura da sociologia das relações raciais a partir do conceito weberiano de status com o objetivo de apontar o papel da raça no sistema de estratificação social brasileiro e suas implicações para a inserção dos negros nas classes médias e altas. Veremos, por exemplo, que a proeminência de hierarquizações baseadas caracteres adscritos dificulta a mobilidade social dos negros, bem como o estabelecimento destes nas camadas sociais mais altas.

Na segunda parte, também trataremos de hierarquizações, mas especificamente daquelas relacionadas a diferentes espaços. Apresentaremos as teorias de Pierre Bourdieu que propõem que as estruturas sociais encontram-se refletidas no espaço. Por fim, abordaremos estudos brasileiros que trataram das relações entre estratificação social e espaço, corroborando, mas também colocando algumas nuances para a proposta de Bourdieu.

\subsection{Raça, Classe e Status}

As possibilidades e/ou os mecanismos de ascensão social dos negros sempre foram um tema chave desde o princípio da sociologia das relações raciais no Brasil. As pesquisas que fundaram este campo de estudos em nosso país buscavam, entre outros objetivos, distinguir as fronteiras entre o preconceito racial (contra os negros) e de classe (contra os pobres). Nesse sentido, o negro que ascendia socialmente tornava-se um importante objeto de estudo, e a questão de fundo era saber em que medida a raça seria ou não barreira para a mobilidade. Ademais, dado que naquele contexto a modernização do Brasil estava ainda em seu princípio, estas pesquisas almejavam, também, o objetivo mais geral de determinar se a sociedade brasileira se caracterizaria pela fluidez das modernas sociedades de classes ou pela rigidez das sociedades de castas pré-modernas. 
Alguns autores defenderam a possibilidade da ascensão individual de pretos e mestiços de acordo com seus próprios méritos. As barreiras existentes seriam decorrentes de sua situação de classe original, ou seja, de provirem das classes baixas. Assim, estas barreiras foram interpretadas como questões de aculturação aos modos das classes mais altas. Para Donald Pierson (1971 [1942]) (e seus seguidores) esta possibilidade de ascensão poderia indicar a menor influência da raça e qualificar a nossa sociedade como uma sociedade multirracial de classes, e não de castas.

Por outro lado, constatou-se que esta possibilidade de ascensão, além de ser muito limitada e restrita a poucas pessoas, vinha acompanhada de uma série de entraves, principalmente relacionados a dificuldades de aceitação de negros nos círculos sociais de elite. Tais constatações levaram alguns autores clássicos como Florestan Fernandes, Oracy Nogueira e Thales de Azevedo a conceber os grupos raciais no Brasil como grupos de status (Cf. Guimarães 2005).

Esta seção realiza um debate com estudos da sociologia das relações raciais que trataram de negros posicionados em camadas médias e altas da estratificação social. Para tanto, trabalharemos com o conceito de status, apoiados na teoria de Max Weber. Tal escolha justifica-se por ser este um conceito que nos proporciona um enquadramento teórico mais adequado à questão investigada, o posicionamento dos negros na estrutura social. Além disso, a noção de status (ou estamentos) pode ser utilizada como chave de leitura para os estudos que abordam a inserção da população negra na sociedade de classes e pode nos sugerir algumas hipóteses para o estudo dos negros em estratos médios e altos. Segundo Weber,

\footnotetext{
“Os estamentos, em contraste com as classes, são, em regra, comunidades, ainda que freqüentemente de natureza amorfa. Em oposição à 'situação de classe', determinada por fatores puramente econômicos, compreendemos por 'situação estamental' aquele componente típico do destino vital humano que está condicionado por uma específica avaliação social, positiva ou negativa, da honra, vinculada a determinada qualidade comum a muitas pessoas. Esta honra pode também estar ligada a determinada situação de classe: as diferenças de classe combinam-se das formas mais variadas às diferenças estamentais, e a propriedade como tal, conforme já observamos, nem sempre, mas com regularidade extraordinária, adquire, a longo prazo, também significação estamental.

(...) Quanto ao conteúdo, a honra estamental costuma encontrar sua expressão na exigência de uma condução de vida específica, dirigida a todos que querem fazer
} 
parte do círculo. E em conexão com isto, também na 'limitação' ao círculo estamental, até o pleno fechamento endógeno das relações sociais (...)" (Weber 2004: 180-1)

Nesta perspectiva, os grupos de status ou estamentos - em contraste com as classes sociais, que se baseiam na situação dos indivíduos no mercado - têm sua origem na avaliação social atribuída a indivíduos portadores de determinadas características selecionadas, interferindo em seu destino vital. As características ou qualidades em comum das quais decorrem as avaliações podem ser diversas: marcas fenotípicas, pertença a famílias ou redes de sociabilidade, posse de um saber, tempo de residência em espaços, exercício de ocupações, pertença a uma dada classe social, etc. Como conseqüência, as pessoas e grupos semelhantemente avaliados expressam sua pertença a um dado grupo de prestígio através da "estilização da vida" e do cultivo de relações sociais e até de casamentos dentro do "círculo estamental", de modo que estes modos de conduzir a vida e a pertença a estes círculos tornam-se, também, características avaliativas que denotam um certo grau de prestígio.

Weber afirma ainda que apesar dos grupos de status conviverem com as classes sociais nas sociedades modernas e de atuarem no sentido de reforçar os contrastes das situações econômicas, eles representam um entrave ao total desenvolvimento da concorrência e de um real livre mercado. Além de causarem prejuízos à inserção dos grupos negativamente avaliados no mercado. $\mathrm{O}$ autor pontua também que o caso extremo dos grupos de status remete à formação de castas fechadas.

Nelson do Valle Silva (1973) analisa a estratificação social no Brasil a partir das definições de classe e de estamento (ou grupo de status) de Weber. Ele postula que há duas dimensões da estratificação social: a dimensão objetiva da diferenciação - que enfatiza a posição objetiva "do indivíduo na organização social da produção como determinante da classe social a que ele pertence" - e a dimensão subjetiva da avaliação de prestígio, que corresponde ao status. Para além disso, Silva pressupõe que há uma congruência entre estas duas dimensões. ${ }^{7}$ O que em termos weberianos, equivale a dizer que toda classe tem seu status, ou que às classes sociais correspondem uma hierarquia de prestígio nas representações das pessoas.

\footnotetext{
${ }^{7}$ Como evidência, Silva (1973) aponta estudos que demonstram a correlação entre a renda e o grau de escolaridade médios de determinadas ocupações (diferenciação) e o prestígio (avaliação) de que gozam tais ocupações na sociedade.
} 
Posto isto, podemos agora distinguir mais facilmente os noções de status atribuído e status adquirido. A última se refere ao status que o indivíduo adquire, em contextos de mobilidade social, na medida em que se posiciona na estrutura de classes. Em outras palavras, o status adquirido resulta da classe social na qual o indivíduo está posicionado. Quanto ao status atribuído, este corresponde às avaliações mais resistentes à mudança, mesmo que o indivíduo mude sua situação no mercado. Ao status atribuído correspondem, por exemplo, avaliações que incidem sobre caracteres adscritos (como raça e gênero) ou pertenças sociais familiares. ${ }^{8}$ Assim, mantido o pressuposto de que às posições de classe deveriam corresponder um certo grau de prestígio, o status adquirido, então o indivíduo que exerce determinada ocupação, tem determinado grau educacional ou aufere uma certa renda deveria gozar do prestígio referente a esta ocupação. Entretanto, existem outros fatores que interferem ou alteram a avaliação social, sendo que os principais remetem ao status atribuído ou, mais especificamente, avaliações baseadas em caracteres adscritos como a cor ou raça.

\section{O Tema da Ascensão Social na Sociologia das Relações Raciais}

Pontuadas estas noções, nos concentraremos aqui nos autores clássicos da sociologia das relações raciais que, segundo Guimarães (2005), caracterizaram os grupos raciais no Brasil como grupos de status: Thales de Azevedo, Oracy Nogueira e Florestan Fernandes. Os trabalhos aqui considerados foram produzidos entre as décadas de 1950 e 1960 (impulsionados pelo Projeto UNESCO de relações raciais) a partir de pesquisas realizadas em diferentes localidades: na Bahia, no caso de Azevedo; Oracy Nogueira fez seu estudo em Itapetininga, cidade do interior de São Paulo; e Florestan Fernandes na própria cidade de São Paulo.

Azevedo e Nogueira, influenciados por Donald Pierson, herdaram os aportes teórico-metodológicos da Escola de Chicago e seus "estudos de comunidade", tendo, portanto um modo individualista de conceber os grupos, ou seja, as classes e os grupos

\footnotetext{
${ }^{8}$ As noções de status adquirido e status adscrito são assim definidas por Robert King Merton: "Considerem-se as sequiências daquilo que Linton denominou status alcançados (ou, mais geralmente, aquilo que pode ser denominado status adquiridos): status nos quais os indivíduos se movem em virtude de suas próprias realizações, mais do que por terem sido colocadas nelas em virtude do nascimento afortunado ou desafortunado, (os quais então seriam status adscritos). A idéia principal é que os componentes dos grupos de status não são combinados ao acaso. Um processo de auto-seleção - tanto social como psicológico - opera a fim de reduzir as perspectivas de repartição dos status pelo acaso." (Merton 1970: 474, grifos do autor.)
} 
raciais seriam definidos a partir de seus integrantes, como grupos de pertença identitária definidos a partir da auto-classificação dos indivíduos que os integram. Florestan Fernandes, por outro lado, propõe uma abordagem estrutural, concebendo os grupos raciais e as classes sociais a partir de posições na estrutura social.

Thales de Azevedo, em seu estudo sobre a ascensão das "pessoas de cor" na Bahia na década de 1950 - que resultou no livro As Elites de Cor (1996 [1953]) defendia que o Brasil se caracterizava por ser uma sociedade multirracial de classes.

\begin{abstract}
"Mas como a sociedade baiana é uma sociedade multi-racial de classes, em que realmente não há castas, isto é, grupos fechados, cujos componentes são hereditariamente classificados e não têm possibilidades de mudar a sua localização social ou de passar para outros grupos, as pessoas de cor têm o seu status condicionado por suas qualidades e aptidões individuais, competindo em igualdade de condições com os brancos (Azevedo 1996 [1953]: 163-4). ${ }^{9}$
\end{abstract}

Contudo, no próprio As Elites de Cor, o autor aponta dificuldades enfrentadas pelos negros nos círculos da elite baiana.

Azevedo (1996 [1953]) utiliza a expressão "mundo dos brancos" para referir-se às elites. Trata-se de determinados círculos sociais nos quais um negro só pode adentrar desde que ostente determinados pré-requisitos como "dinheiro, ilustração, maneiras, (...) boas relações pessoais e familiares" (p. 70). ${ }^{10}$ Ascender, para um negro, é integrarse a este "mundo dos brancos", o que implica adotar os padrões de comportamento dominantes e adaptar-se às expectativas dos brancos para, dessa maneira, ser aceito naqueles círculos. A aceitação em certas organizações religiosas ou em clubes (nos quais o acesso é mais difícil) ratifica a posição social - ou, nas palavras de Azevedo, são um meio de "confirmação de status para as pessoas de cor".

Entretanto, a medida na qual um negro pode partilhar deste status de elite tornase uma questão problemática se considerarmos aqueles requisitos e adaptações menos como uma questão de "aculturação e integração das massas", e mais como barreiras de distinção, segundo se pode entender a partir das próprias descrições que autor faz das

\footnotetext{
${ }^{9}$ Como evidência de que não apenas as classes, mas também os grupos raciais constituem grupos abertos, Azevedo cita o fato de que as categorias de cor poderiam variar segundo a posição social do indivíduo.

${ }^{10}$ A partir da descrição dos "círculos da elite baiana" feita por Azevedo (1996 [1953]), podemos atribuir o conceito weberiano de grupo de status a estas elites.
} 
cobranças e desconfianças pelas quais passam as pessoas de cor quando adentram estes círculos.

"O brancos esperam que as pessoas de cor, especialmente as mais escuras, sejam comedidas em seus gestos, modestas e que, apesar dos méritos pessoais, guardem certa distância delas. E aqueles sabem muito bem disso". (Azevedo 1996 [1953]: 68)

Isto faz com que os negros evitem certos lugares e certas atitudes. São policiados em questão de educação e maneiras, correndo sempre o risco de serem considerados ou excessivamente humildes e submissos, ou pretensiosos, viciosos, exagerados em seus modos, ansiosos por se mostrarem. Em suma, sobre um preto pesa sempre a questão dos modos que, segundo o preconceito corrente, deveriam ser identificados aos modos da classe baixa. Assim, podemos considerar que o status adquirido, típico da sociedade de classes, é precário quando se trata de um negro que ascende. ${ }^{11}$

No artigo posterior "Classes Sociais e Grupos de Prestígio" (1966 [1956]), o autor é mais sensível aos entraves à aceitação dos negros na elite baiana, à prevalência do status atribuído sobre o status adquirido e à consequiente dificuldade de consolidação da ordem moderna de classes. Azevedo reformula a sua interpretação da estrutura da sociedade baiana de então, na qual as modernas classes sociais coexistem com grupos de status (ou grupos de prestígio), que caracterizavam a sociedade escravocrata. Deste modo, a partir dos conceitos de classe e de status de Weber e Tönnies, Azevedo admite que "há um círculo de relações pessoais, definido a partir da cor e da origem familiar, que constitui uma real comunidade de status, a fazer dos brancos, ricos, e dos pretos, pobres" (Guimarães 2005: 82). ${ }^{12}$ Replicando assim, a estrutura social do período escravista polarizada pelos senhores brancos e os escravos negros.

De acordo com o autor, a Bahia não teria concluído a passagem de uma sociedade de status para uma sociedade exclusiva ou preponderantemente de classes sociais. Persistindo, ainda, uma correlação entre status e cor que dividiria a sociedade em dois grupos de prestígio. As pessoas de status mais elevado são identificadas aos

\footnotetext{
${ }^{11}$ De acordo com Azevedo (1996 [1953]), a dificuldade de aquisição de um status de elite por um negro também pode ser notada através da forte oposição ao casamento inter-racial nas classes mais elevadas (mesmo se tratando de "pretos de destaque").

${ }^{12}$ Guimarães nota ainda que em "Classes Sociais e Grupos de Prestígio", "Status passa a referir-se, então, a uma hierarquia social peculiar, os Stände, e não apenas ao prestígio social associado a qualquer hierarquia”. (Guimarães 2005: 155)
} 
brancos e as pessoas de status mais baixo identificadas aos negros. Desta maneira, "negritude" ou "branquitude" relacionam-se, ao mesmo tempo, a caracteres físicos e à posição social. Assim, "uma pessoa de traços negróides é considerada branca se é rica ou tem papel de relevo" (Azevedo 1966 [1956]: 33), e vice-e-versa.

Durante o incipiente processo de modernização baiano, começam a emergir classes sociais ajustadas a esta hierarquia de prestígio. A hierarquia de classes - baseada em relações abertas e de mercado - divide a sociedade em classe alta, média e baixa. A hierarquia de prestígio divide a sociedade em dois grupos de status: o dos brancos-ricos, que incorpora a classe média (inclusive a mestiça e letrada), e o dos pretos-pobres, que incorpora os pobres e iletrados, ainda que de cor branca.

O autor conclui que na sociedade baiana "o status resulta de uma combinação de fatores como nascimento e tipo físico, que se deixam modificar, até certo ponto, pela fortuna, pela ocupação e pela educação. $O$ status de nascimento e a cor limitam a distância social que é possível percorrer no processo de mobilidade vertical, quaisquer que sejam os demais elementos condicionantes" (Azevedo 1966 [1956]: 42).

Oracy Nogueira (1998 [1955]) realizou um estudo de comunidade na cidade de Itapetininga, no interior de São Paulo, enfocando as relações raciais nesta localidade. Em seu trabalho, os pretos e pardos podem ser considerados como formando um grupo de status a partir de sua situação de objeto de discriminação - ou de "preterição social" nas palavras do autor - mantido nas mais baixas posições da estrutura social.

\footnotetext{
“A cor branca facilita a ascensão social, porém, não a garante por si mesma; de outro lado, a cor escura implica antes uma preterição social que uma exclusão incondicional de seu portador." (Nogueira 1998 [1955]: 167).
}

Com relação à aceitação dos negros nas associações e clubes recreativos das elites, o autor conclui que

“(...) em igualdade de condições de classe, o indivíduo de cor poderá sofrer preterição, sendo, portanto, mais efetivas as barreiras que se lhe opõem do que, normalmente, tem de enfrentar o candidato branco.

Os casos excepcionais de indivíduos de cor admitidos aos quadros sociais de associações das classes alta e média indicam que sua admissibilidade está condicionada a uma superioridade intelectual, ocupacional, de fortuna ou de 
qualquer outra natureza em relação à maior parte dos consórcios brancos” (Nogueira 1998 [1955]: 181).

Ademais, é interessante acrescentar que, para Nogueira, as transformações pelas quais a sociedade de então passava - com os processos de modernização, industrialização e urbanização - levariam a um predomínio dos contatos secundários sobre os primários, de maneira que a identificação pessoal, mais próxima e afetiva, fosse substituída por atitudes baseadas em estereótipos. Torna-se, assim, "mais inseguro o status dos elementos de cor em ascensão, fazendo com que a consciência de cor que, nas condições de um grupo em que os contatos eram quase exclusivamente primários era ocasional ou intermitente, se torne cada vez mais constante ou contínua" (Nogueira 1998 [1955]: 245).

Florestan Fernandes (1978 [1965]), ao analisar a integração da população negra no processo de modernização de São Paulo, afirma que:

Na verdade, o negro e o mulato são expostos, normalmente, a uma perda real de prestígio social, como se os níveis de classificação da sociedade global não tivessem eficácia para eles. A cor aparece, a um tempo, como marca racial e como símbolo de status. Por isso, ela serve, inextricavelmente, para identificar o negro e o mulato como categoria racial (como "preto") e como categoria social (como "classe mais baixa").

(...) Todavia, como os diferentes níveis sociais não estão saturados nas mesmas proporções por negros e mulatos, o "branco" pode ignorar o fato e agir segundo práticas convencionais, que lhe facultam uma arbitrariedade elástica no tratamento do "preto". Ele tanto pode deixar de "tratar como preto" um 'indivíduo de cor' pertencente a uma categoria social inferior à sua, quanto pode "tratar como preto" 'um indivíduo de cor' do mesmo nível social ou de nível social superior ao seu" (Fernandes (1978 [1965]: 247)

Para Fernandes (1978 [1965]), a implantação da sociedade de classes no Brasil conservou hierarquias da ordem escravocrata, integrando os negros de modo subordinado. Ou seja, a nossa sociedade não se enquadra completamente no tipo ideal da sociedade de classes, conservando aspectos da sociedade de castas, como a operação de características adscritas na definição das oportunidades das pessoas, em particular, dos negros. 
A vigência dos padrões tradicionalistas de relações raciais implicava a perpetuação de expectativas de comportamento, ideais de personalidade, concepções de status e de papéis sociais, nas quais os negros eram identificados às posições subordinadas. $\mathrm{O}$ resultado é que, num contexto em que apenas os contingentes brancos foram englobados pelo regime de classes, os negros viviam numa sociedade organizada em classes sem, contudo, participar do regime de classes em sua plenitude.

Não obstante, o crescente processo de industrialização ocorrido após a Segunda Guerra Mundial permitiu o ingresso dos negros em vários ramos do trabalho assalariado. Essas novas chances de estabelecimento nos postos de trabalho davam aos negros possibilidades de competir com os brancos e de ascender socialmente.

Deste processo de diferenciação resulta a chamada "classe média de cor", que não necessariamente era composta por indivíduos em situação de classe média, mas, em geral, por pessoas que, obtendo empregos estáveis, encontravam-se num processo de ascensão social e de integração à sociedade de classes, representando um diferencial de prestígio diante da massa negra.

Entretanto, a ascensão não modificou o status com relação ao branco, de maneira que o negro era sempre alvo de discriminação e desconfiança, não vendo reconhecida a sua posição de classe. Isto implicava reações de defesa de status como: a adoção de um estilo de vida puritano, como forma de evitar o estereótipo de desordeiro e vagabundo; a ostentação de sinais de riqueza e de um status fictício, como o vestuário ou mudança de residência; e o isolamento em organizações, clubes e redes de sociabilidades exclusivas da "classe média de cor".

O conceito weberiano de status pode ser identificado nos três autores acima segundo três sentidos diferentes. O primeiro indica que a cor é um dado que interfere negativamente no processo de avaliação que atribui status às pessoas, resultando em entraves específicos à ascensão e à classificação em determinadas posições sociais, conformando, assim, uma peculiar configuração da estrutura social. Em outras palavras, o efeito do prestígio negativo de seus traços fenotípicos resulta em prejuízos para os negros na sua alocação no sistema de posições de classes.

Os outros dois sentidos remetem à "estilização da vida": os modos de comportamento e de consumo compartilhados por certos grupos; e a pertença ou aceitação em determinados círculos de sociabilidade. Ambos os fatores também interferem na imputação de prestígio a determinados indivíduos, sendo abordados pelos 
autores tratados acima como formas de legitimação da aquisição de um determinado status, e constituindo barreiras de aquisição de status para os negros. Assim, não bastava exercer uma ocupação de prestígio ou ter alto grau educacional se não se adquirisse os modos e comportamentos do grupo de maior status, ou se não fosse aceito nos clubes e na sociabilidade do grupo de maior status.

Thales de Azevedo, Oracy Nogueira e Florestan Fernandes trataram de um contexto de incipiente modernização no Brasil e subjaz à própria aplicação do conceito de status aos grupos raciais a idéia de que a sociedade de classes brasileira estava ainda em formação. Para Florestan Fernandes, o preconceito de cor e as barreiras à ascensão dos negros seriam indícios de que a implantação das modernas classes sociais no Brasil era um processo ainda incompleto. Havendo, portanto, a expectativa de que o avanço da modernização superaria estes arcaísmos do passado escravocrata.

\section{Carlos Hasenbalg e as novas perspectivas sobre negros que ascenderam}

No ano de 1979, é publicado o trabalho de Carlos Hasenbalg (2005 [1979]), que contraria as expectativas da geração anterior ao demonstrar a permanência do preconceito racial, não como herança residual do passado escravocrata, mas como mecanismo de reprodução das desigualdades raciais na própria sociedade de classes. Assim, o autor indica que prevalece a avaliação de caracteres adscritos - no caso, a cor - no preenchimento de posições na estrutura social brasileira, implicando na reprodução das dificuldades de ascensão e de legitimação da ascensão enfrentadas pelos negros.

\footnotetext{
“A proposição mais geral é a de que a raça opera como um critério com uma eficácia própria no preenchimento, por não-brancos, de lugares na estrutura de classes e no sistema de estratificação social. (...) Outrossim, o racismo, como construção ideológica incorporada em e realizada através de um conjunto de práticas materiais de discriminação racial, é o determinante primário da posição dos não-brancos nas relações de produção e distribuição" (Hasenbalg 2005: 120-1).
}

Hasenbalg aponta a raça como um atributo que opera na alocação dos indivíduos na estrutura de posições do sistema de classes brasileiro, dificultando a mobilidade social ascendente dos negros, e mantendo-os nas posições inferiores. Assim, na competição pela mobilidade ascendente, primeiramente, os negros são desfavorecidos 
no ponto de partida, pois em sua maioria, originam-se de famílias de baixa posição social. Em acréscimo, os efeitos do racismo fazem com que as trajetórias sejam marcadas por um processo de acumulação de desvantagens.

\footnotetext{
"Em comparação com os brancos, os não-brancos sofrem uma desvantagem competitiva em todas as fases do processo de transmissão de status. Devido aos efeitos de práticas discriminatórias sutis e de mecanismos racistas mais gerais, os não-brancos têm oportunidades educacionais mais limitadas que os brancos de mesma origem social. Por sua vez, as realizações educacionais dos negros e mulatos são traduzidas em ganhos ocupacionais e de renda proporcionalmente menores que os dos brancos" (Hasenbalg 2005: 230).
}

Carlos Hasenbalg representa um marco na introdução de novas abordagens na sociologia das relações raciais, com estudos que enfocam a interferência da raça no processo de realização sócio-econômica e mobilidade social. A partir de pesquisas que articulavam raça com educação, mercado de trabalho e mobilidade social, a discriminação racial passa a ser deduzida dos diferenciais de realização educacional, ocupacional e de mobilidade entre brancos e negros. Ou seja, os estudos passaram a identificar os efeitos do racismo através de seus resultados na estrutura social.

De acordo com Guimarães (2004):

\begin{abstract}
“(...) os anos 1980 e 1990 serão tomados na sociologia brasileira pelo avanço dessas novas teses e novidades conceituais que se irradiarão a partir do trabalho conjunto de Carlos Hasenbalg e Nelson do Valle Silva (...). Podemos mesmo ver na ação institucional de ambos um certo programa de trabalho, no qual, ao lado dos estudos de desigualdades raciais, que utilizam modelos matemáticos cada vez mais refinados, se desenvolvem estudos especializados por áreas (educação e mercado de trabalho, principalmente), ou estudos que buscam descobrir os micromecanismos de discriminação (no âmbito da escola, do livro didático, da sala de aula, da mídia, da propaganda, dos locais de trabalho, dos locais de consumo e do mercado de trabalho etc.)." (Guimarães 2004: 27-8).
\end{abstract}

Neste contexto estão estudos recentes que tratam de negros posicionados em estratos mais altos, retomando um objeto de estudos considerado importante desde os clássicos da sociologia das relações raciais (haja vista As Elites de Cor, de Thales do Azevedo), mas em diálogo com estas novas abordagens. Dentre as pesquisas que 
abordam estes objetos, dialogaremos com os trabalhos de Figueiredo (2002, 2003) sobre profissionais liberais e empresários negros em Salvador, de Soares (2004) sobre negros de classe média associados a organizações que congregam paulistanos deste grupo, e de Lima (2001) que, ao tratar sobre cor e mercado de trabalho, aborda negros que exercem ocupações de prestígio no Rio de Janeiro.

Estes estudos identificam a persistência de certos problemas em torno da ascensão de negros levantados pelos autores clássicos, o que requer que retomemos algumas questões discutidas por eles. Consideremos o conceito de status e suas acepções aqui descritas. Poderemos recorrer a ele para refletir sobre a classe média negra de hoje? Até que ponto ele se aplica?

Os trabalhos de Ângela Figueiredo (2002; 2003) e de Reinaldo Soares (2004) sobre negros de classe média dão maior ênfase aos efeitos da avaliação de status para a realização de estilos de vida e para a participação em certos círculos de sociabilidade.

Reinaldo Soares (2004) pesquisou membros de associações que reúnem negros de classe média que, assim como a classe média negra pesquisada por Florestan Fernandes, têm sua sociabilidade restrita a estes espaços freqüentados apenas por negros do mesmo estrato que o seu. Por um lado, porque não eram bem aceitos na sociabilidade dos brancos de seus estratos, e, por outro lado, porque procuravam distinguirem-se e evitar estereótipos que os associassem às "massas de cor".

Não obstante, Soares afirma que o grupo estudado apresenta uma combinação de habitus das classes médias e das camadas populares que não estão associados a nenhum exclusivismo de classe. Segundo ele: "O sistema de gostos dos negros de classe média reflete a trajetória de ascensão social do grupo, numa transição entre aspectos de estilo de vida da classe trabalhadora e das camadas médias" (p. 147).

Os empresários e profissionais liberais entrevistados por Figueiredo (2002; 2003), ao passo que não se consideram "membros da classe média" pelo fato de não compartilharem da sociabilidade do grupo que eles vêem como sendo a classe média de fato, por outro lado, afirmam-se como negros, contrariando a noção de que com a ascensão social os negros tenderiam a se afastar desse tipo de identificação. A origem disso partiria das situações de discriminação às quais os negros de classe média estariam mais expostos.

A autora realça o fato de que os negros que ascendem pagam um alto preço por estarem "fora do lugar" sociologicamente construído e simbolicamente 
determinado, sendo alvo de preconceitos e discriminações.

\begin{abstract}
“(...) enquanto ocupavam a base da estratificação sócio-econômica, e viviam em bairros pobres, esses indivíduos não se sentiam fora de lugar e não eram vistos como tais. Situação oposta ao que ocorre quando eles passam a exercer cargos de comando, ocupar posição de destaque no mercado de trabalho, morar em bairros de classe média (...), se dirigem aos espaços sociais freqüentados pela classe média, a exemplo de bares, lojas e restaurantes e quando matriculam os seus filhos em boas escolas particulares.” (Figueiredo 2004: 227-8)
\end{abstract}

Ao freqüentarem estes espaços e tentarem desfrutar de sua posição econômica elevada, através do consumo de bens e serviços considerados caros ou luxuosos, por exemplo, estes indivíduos costumam ser discriminados, encarados com curiosidade ou tratados com desconfiança.

\footnotetext{
Desse modo, eles são levados a refletir sobre a sua condição étnico-racial e sobre os limites da ideologia racial brasileira. (...) restando apenas a possibilidade da assunção de uma identidade étnico-racial tardia..” (Figueiredo 2004: 208-9)
}

Ou seja, o fortalecimento da identidade étnica e o cultivo de um "orgulho da cor e da ascendência negra" (Figueiredo 2002: 116) verificados durante o processo de ascensão trata-se, segundo ela, de uma forma de resposta às situações de discriminação, que se tornam cada vez mais fortes quanto mais alto for o estrato social.

Em suma, Figueiredo (2002, 2003, 2004) mostra que, apesar de terem conquistado condições educacionais e materiais para acessar bens, espaços e estilos de vida típicos das camadas mais altas, os negros superiormente posicionados continuam a ter problemas por serem encarados como indivíduos "fora do lugar". Estas constatações evidenciam, para os próprios atores, a natureza racial do problema, suscitando, neles, a assunção da identidade negra a partir da percepção de ser alvo de discriminação.

Esta idéia de "lugar" a qual Figueiredo $(2003,2004)$ se refere, foi anteriormente utilizada por Márcia Lima (2001) para analisar a relação entre cor e trabalho. "O 'lugar' do negro no marcado de trabalho tem sido o lugar das ocupações de menor prestígio, baixa escolaridade e baixos rendimentos. A partir dessas condições, criou- 
se uma representação na sociedade brasileira de que há lugares estabelecidos. Há um padrão e o negro que ascende socialmente está saindo dele." (Lima 2001: 157). ${ }^{13}$

Lima retoma as teorias de Estigma, de Erwing Goffman para mostrar o modo pelo qual os estereótipos atuam nos momentos em que os indivíduos classificam uns aos outros, atribuindo-lhes determinados "lugares". Havendo, no Brasil, uma visão estigmatizada entre ser negro e realizar determinados trabalhos, resultando que certos nichos ocupacionais sejam vistos como "serviço de preto". Deste modo, a autora conclui que "O que se percebe é que há uma idealização de características para a realização de determinadas atividades e nessa idealização, há uma construção em torno da cor." (Lima 2001: 201)

Assim, a idéia de "lugar do negro" surge da constatação de que existe uma construção social naturalizada pelas pessoas, através da qual os atores acionam estereótipos ligados a determinados caracteres fenotípicos para, assim, conceber os "lugares prováveis" que determinadas categorias de indivíduos deveriam ocupar.

Com relação a esta naturalização, convém uma alusão a outro trabalho de Figueiredo (2000), no qual autora compara as opiniões de chefes de famílias brancas e negras sobre o quanto eles gostariam de auferir mensalmente para obterem determinados padrões de vida ideais. Ou seja, qual seria a renda ideal para os chefes de família. Os chefes de família brancos sempre indicavam valores maiores que os chefes de família negros. Figueiredo (2000) interpretou estes dados como representativos da interiorização, no plano das subjetividades, das diferenças reais e simbólicas entre brancos e negros (uma "interiorização das desigualdades"). Pois seja lá qual fosse a classe social, escolaridade e região, os negros sempre apontavam valores menores. ${ }^{14}$

Assim, apesar do crescimento numérico da presença de negros nos estratos médios e altos, talvez a expressão "mundo dos brancos" empregada por Azevedo ainda pode ser utilizada para descrever o grupo de status correspondente aos estratos médios e altos brasileiros, dadas a predominância de brancos e as discriminações e barreiras à inserção social dos negros nestes estratos. Os negros, superando as dificuldades de

\footnotetext{
${ }^{13}$ A autora acrescenta que “(...) entretanto, devemos lembrar que há lugares para os negros em ocupações com altos rendimentos - como um mundo artístico e esportivo - como não há uma inserção fácil dos "negros" em algumas ocupações de baixa renda, onde a discriminação pela aparência atua como uma forma de exclusão, como por exemplo, vendedores, garçons, recepcionistas." (Lima 2001: 157-8).

${ }^{14}$ Rodrigo Ednilson de Jesus (2008) também constata este tipo de diferença nas aspirações ocupacionais de negros e brancos.
} 
ascensão, podem até atingir uma posição de classe média, mas enfrentam dificuldades para ter sua posição reconhecida socialmente e, também, para identificarem-se a esta camada.

Antonio Sérgio Guimarães: raça informando as "classes nativas”

Tais constatações estão ligadas a uma característica das representações sobre classe social no Brasil, para a qual chama atenção Antonio Sérgio Guimarães (2002). De acordo com este autor, devemos distinguir, por um lado, as representações da estrutura e das hierarquias sociais presentes no senso comum, chamadas "classes nativas", "pré-sociológicas", e por outro, o conceito analítico de classe utilizado pela sociologia, chamado de "classes teóricas". No Brasil, hierarquias de status baseadas em caracteres adscritos como a raça orientam as concepções "nativas" de classe, naturalizando, por exemplo, a idéia de que as classes médias e altas seriam um "mundo dos brancos".

\footnotetext{
"No Brasil, onde as discriminações raciais (aquelas determinadas pelas noções de raça e cor) são amplamente consideradas, pelo senso comum, como discriminações de classe, o sentido pré-sociológico do termo nunca deixou de ter vigência. Este sentido ancien do termo "classe" pode ser compreendido como pertencendo à ordem das desigualdades de direitos, da distribuição da honra e do prestígio sociais, em sociedades capitalistas e modernas, onde permaneceu razoavelmente intacta uma ordem hierárquica de privilégios, e onde as classes médias não foram capazes de desfazer os privilégios sociais, e de estabelecer os ideários de igualdade e de cidadania." (Guimarães 2002: 43).
}

Deste modo, Guimarães sugere que a raça seria uma marca de "classe", orientaria representações sobre "classe", em seu sentido nativo, não sociológico. E então, nestas representações nativas de classe, não apenas as classes mais altas como também as posições hierárquicas superiores em geral não seriam nunca vistas como um "lugar possível" para negros, uma vez que estes carregam características fenotípicas que permanecem sendo relacionadas às posições hierárquicas mais baixas.

Em suma, através da discussão realizada nesta seção procuramos demonstrar o fato da raça ser um atributo adscrito que interfere na estratificação social, mais 
especificamente na própria alocação dos negros na estrutura de posições de classes e no não reconhecimento dos negros como ocupantes igualmente legítimos de posições mais privilegiadas da estratificação (a partir do fato de que as representações "nativas" de classe são informadas por representações sobre a cor).

Como vimos acima, Weber mostra que as pessoas e grupos semelhantemente avaliados expressam sua pertença a um dado grupo de prestígio através da estilização da vida e do cultivo do que Telles chamou de relações horizontais - como a sociabilidade e casamentos dentro do "círculo estamental". De modo que estas formas de conduzir a vida e estas relações horizontais tornam-se, também, características avaliativas que informam graus de prestígio.

Assim, quando Telles diz que a classe média branca mantém os negros afastados (Cf. Telles 2003: 318) entendemos isso como uma manutenção das linhas que distinguem os grupos de status. A segregação residencial entre negros e brancos nos estratos mais altos manteria a distância social entre estes grupos e ajudaria a instituir o que Telles chamou de "barreiras invisíveis à ascensão dos negros".

No decorrer desta dissertação, exploraremos a idéia segundo a qual o fato de que os negros de classe média não sejam vistos como classe média nas representações nativas de classe encontra apoio na localização residencial deste grupo, o que também ajuda a cristalizar estas representações. O fato de estarem fisicamente distantes dos brancos dos mesmos estratos contribui para que não sejam reconhecidos como pertencentes a estes estratos e, inversamente, o fato de não serem vistos (e nem se verem) como possíveis moradores legítimos de bairros de classe média e alta (pois lá não é "lugar de negro") contribui para que sejam mantidos fora destes espaços.

Demonstraremos, mais adiante, que os negros de classe média ocupam uma posição elevada na hierarquia social, mas residem em bairros periféricos, onde também vive uma grande proporção da população mais pobre e que são desprestigiados nas avaliações sociais sobre o espaço urbano. Nossa proposta é introduzir a variável espaço no estudo deste grupo e considerar a localização residencial de seus membros, como um aspecto relevante para a caracterização da classe média negra. A seguir, abordaremos as relações entre espaço e estratificação social. 


\subsection{Espaço e Estrutura Social}

Esta segunda parte visa abordar as perspectivas através das quais trataremos a questão do espaço neste trabalho. Consideraremos aqui o espaço, não apenas como variável dependente da estrutura social, mas também como atributo que orienta avaliações sociais e constitui diferenciações entre os indivíduos e grupos.

Retornando à definição dada por Weber ao conceito de status - como derivado de uma avaliação social atribuída a indivíduos que possuem determinada característica em comum -, gostaríamos de enfatizar o fato de que as qualidades comuns sobre as quais podem incidir as avaliações sociais de prestígio dos indivíduos e, consequientemente, interferir em seus destinos pessoais, podem ser dos mais diversos tipos. Ou seja, o conceito de status pode ser aplicado a múltiplas dimensões - nãoeconômicas - que operam classificando as pessoas e, interferindo nas suas respectivas situações de mercado.

Assim, a residência em uma determinada área ou bairro da cidade pode gerar avaliações de prestígio (positivas ou negativas) que interfiram no destino e nas possibilidades de realização pessoal de indivíduos ali localizados. Além disso, o local de residência também pode ser base para a formação de grupos de status na medida em que propicia o cultivo de estilos de vida e círculos de sociabilidade específicos.

\section{Espaço e Estratificação Social em Pierre Bourdieu}

Considerando estas múltiplas dimensões avaliativas às quais se aplicam a noção de status, que criam sistemas classificatórios que hierarquizam os indivíduos e as coisas, Pierre Bourdieu apresenta-nos um esquema teórico que aponta para a possibilidade de uma síntese. De acordo com o autor:

\footnotetext{
"Para restituir às análises weberianas toda sua força a alcance, antes é preciso reconhecer que os grupos de status e as classes constituem unidades nominais que podem restituir a realidade de modo mais ou menos completo segundo o tipo de sociedade, mas que são sempre resultado da opção de acentuar o aspecto econômico ou o aspecto simbólico, aspectos que sempre coexistem na própria realidade (em proporções diferentes conforme as sociedades e as classes sociais de uma mesma
} 
sociedade), uma vez que as distinções simbólicas são sempre secundárias em relação às diferenças econômicas que as primeiras exprimem, transfigurando-as" (Bourdieu 2005: 15).

O autor francês utiliza a idéia de espaço social, no qual se posicionam agentes e grupos. A posição dos agentes neste espaço social é definida pelo volume de capital que possuem. Porém, a noção de capital de Bourdieu não remete apenas à questão material, mas às múltiplas dimensões de capital - econômico, cultural, social e simbólico. Assim, as posições dos agentes são dadas a partir da acumulação de capital nestas distintas dimensões. $\mathrm{E}$ as classes podem ser recortadas a partir da proximidade entre os agentes neste espaço social. Entretanto, as classes não se definem apenas pela sua posição objetiva na estrutura social, mas transformam estas diferenças de posição em diferenças simbólicas ou distinções significativas. (Cf. Bourdieu 1989).

Para Bourdieu (1997), espaço físico habitado seria uma simbolização do espaço social, manifestando as hierarquias e distâncias sociais. Habitar diferentes espaços seria uma das formas de constituição das distinções significativas entre as classes. E, assim, as hierarquizações dos espaços correspondem e naturalizam hierarquias sociais.

Nesse sentido, as localizações dos diversos estratos sociais não só influenciam, como também encontram amparo nas próprias percepções e representações que os indivíduos têm sobre o espaço. Assim, as estruturas sociais objetivadas no espaço físico tendem a se reproduzir na linguagem e nos sistemas de preferência - "isto é, enquanto categorias de percepção e de apreciação ou de estruturas mentais (parisiense / provinciano, chique / não chique, etc.)" (Bourdieu 1997: 162) -, que são reforçados pela própria ordem dos espaços físicos.

\footnotetext{
"O bairro chique, como um clube baseado na exclusão ativa de pessoas indesejáveis, consagra simbolicamente cada um de seus habitantes, permitindo-lhes participar do capital acumulado pelo conjunto dos residentes; ao contrário, o bairro estigmatizado degrada simbolicamente os que o habitam, e que, em troca, o degradam simbolicamente, porquanto, estando privados de todos os trunfos necessários para participar dos diferentes jogos sociais, eles não têm em comum senão sua comum excomunhão." (Bourdieu 1997: 166).
}

Ademais, o autor avança postulando uma subordinação do espaço à estrutura social, ou uma super-determinação do social sobre o espaço. O espaço físico seria uma 
variável dependente do espaço social e uma instância para a sua reprodução. Isto é, a posse de capital, na qual se baseia a organização do espaço social, molda o espaço físico que, por sua vez, atua na própria reprodução das estruturas do espaço social. Assim,

\footnotetext{
“A capacidade de dominar o espaço (...) depende do capital que se possui. O capital permite manter à distância as pessoas e as coisas indesejáveis ao mesmo tempo que aproximar-se de pessoas e coisas desejáveis (...): a proximidade no espaço físico permite que a proximidade no espaço social produza todos os seus efeitos facilitando ou favorecendo a acumulação de capital social.

(...) a mobilidade espacial (...) os endereços sucessivos no espaço hierarquizado (...) é um bom indicador dos sucessos ou dos reveses alcançados nessas lutas e, mais amplamente, de toda a trajetória social.

(...) o essencial das diferenças regionais que se imputam muitas vezes ao efeito de determinismos geográficos podem ser referidas a diferenças de capital (...) reflete, de fato diferenças econômicas e sociais, que se poderia esperar isolar o resíduo irredutível que deveria ser imputado em particular ao efeito da proximidade e da distância no espaço puramente físico.” (Bourdieu 1997:164).
}

Assim, de acordo com as considerações de Bourdieu, a importância do espaço seria apenas residual, e este seria concebido como um suporte moldado pela proeminência das distribuições de capital.

Deste modo, se coloca, portanto, uma questão em torno de qual seria a real especificidade do espaço. Se, por um lado, não podemos afirmar que o espaço tem importância em si. E devemos, portanto, nos remeter aos conteúdos sociais inscritos neste espaço e aos processos sociais que determinam as características de cada espaço, previstos no esquema de Bourdieu. Por outro lado, a variável espaço ganha relevo na medida em que considerarmos configurações sociais específicas de determinados espaços. Ou seja, quais seriam os conteúdos específicos internos a determinados espaços que levariam a diferentes resultados para, por exemplo, as possibilidades de mobilidade social ou para o posicionamento dos indivíduos ali residentes na estrutura social.

Estas questões são abordadas por pesquisas empíricas realizadas no Brasil sobre as relações entre espaço e estrutura social, e que serão matéria da seção seguinte. Sem invalidar as assertivas teóricas de Bourdieu, estas pesquisas nos levam a inserir nuanças em sua teoria, que restabelecem a importância do espaço. 
Trataremos aqui de estudos que demonstram que o esquema teórico de Bourdieu nos fornece noções através das quais podemos descrever diversos fenômenos que observamos em nossa realidade urbana.

Nos trabalhos de Marques, Scalon e Oliveira (2007) - sobre as Regiões Metropolitanas de São Paulo e do Rio de Janeiro -, e Marques e Scalon (2008) - apenas sobre São Paulo -, observamos o poder de apropriação dos espaços a partir do volume de capital acumulado, resultando numa determinada distribuição das classes sociais no espaço urbano que aproxima as camadas com mais capital umas das outras, ou seja, segrega.

\footnotetext{
“A análise espacial exibiu o quadro de segregação geográfica das classes, reafirmando, em grande medida, o argumento de Bourdieu. De certa forma, é possível falar de uma topologia social, na qual há sobreposição do espaço social e do espaço territorial. Colocar as classes em seus lugares revela a distância que existe entre elas. Do mesmo modo, desvenda as fronteiras, muros e barreiras que são construídos não apenas sobre a base das diferenças culturais, de estilo de vida, de poder; mas erguem-se, também, sobre o alicerce da distância espacial.” (Marques e Scalon 2008: 25)
}

De uma forma geral, as pesquisas que tratam da localização das classes sociais nas cidades brasileiras seguem esta mesma linha de argumentação, mesmo quando não se referem à Bourdieu.

Villaça (1999), por exemplo, encontra semelhanças nos padrões residenciais das camadas de alta renda em cinco capitais brasileiras: São Paulo, Rio de Janeiro, Recife, Salvador e Porto Alegre.

Todavia, para além destas demonstrações empíricas, o argumento principal de seu artigo ataca o fato de que muitos estudos negligenciam importância do espaço nos processos de estratificação social e, principalmente, para a manutenção de determinadas configurações sociais. Para este autor, a segregação espacial é um fator necessário para viabilizar a dominação por parte das classes superiores. 


\begin{abstract}
"O papel do espaço consiste no seguinte: dada uma certa estratificação social, dadas as mesmas características socioeconômicas, culturais e políticas da população, a forma como a população e essas características se organizarem no espaço produzirá efeitos sociais diferentes. A segregação - uma determinada configuração espacial é necessária para que haja dominação através do espaço e através dessa dominação haja apropriação diferenciada do produto do trabalho. O espaço produzido está, assim, condicionando o social. Isso não significa reificar o espaço, pois ele próprio é produto social.” (Villaça 1999: 236)
\end{abstract}

As classes superiores se aproveitariam dos padrões de segregação para manterem-se em posição privilegiada através de três mecanismos principais: do controle do mercado imobiliário, que orienta os deslocamentos das centralidades da cidade na direção das maiores concentrações destas classes sociais; do controle do Estado, que realiza políticas urbanas que beneficiam mais os moradores dos bairros nobres; e do controle da ideologia, que dissemina representações que naturalizam as valorações e avaliações das elites sobre os espaços da cidade e promove a idéia segundo a qual " $a$ cidade se identifica com aquela parte da cidade que é de interesse ou é ocupada pela classe dominante" (Villaça 1999: 231).

Apesar do trabalho de Villaça sobre a segregação das camadas mais altas ser considerado um dos clássicos, os estudos urbanos brasileiros, tradicionalmente, têm dado maior ênfase nos processos de segregação de pobres e migrantes em áreas metropolitanas distantes do centro e carentes de infra-estrutura, as periferias (Revisões sobre esta literatura podem ser encontradas em Caldeira 2000, Marques 2005a e em Bichir 2006). Assim, a partir dos estudos clássicos da década de 1970, a distribuição das classes sociais nas metrópoles brasileiras passou a ser pensada segundo um modelo calcado na oposição entre centro e periferia. Desde essa perspectiva, o centro, onde residiriam as classes altas, seria bem provido de infra-estrutura urbana e com amplo acesso a amenidades e equipamentos públicos, enquanto a periferia seria descrita como espaços distantes do centro para os quais seriam canalizadas as populações de baixa renda. Esses locais, de maior concentração das classes trabalhadoras, seriam marcados pela ausência do Estado e de serviços básicos, e pela precariedade das condições de vida e das soluções habitacionais - na maior parte das vezes, baseadas em loteamentos clandestinos e casas construídas pelos próprios moradores com a ajuda de seus amigos ou familiares - e pelo difícil acesso ao mercado de trabalho e aos serviços públicos. 
É forçoso notar que a concepção centro-periferia possui bastante força, não apenas nos debates acadêmicos, mas também em muitos discursos e representações existentes a respeito das periferias. A princípio, estas representações emanavam apenas de fontes externas a estes espaços e vinculavam a estas áreas das cidades estigmas negativos de marginalidade. Atualmente ganham proeminência discursos produzidos por atores provenientes das próprias periferias. Tais discursos - presentes, principalmente, nas canções dos grupos de rap e na chamada literatura periférica manifestam uma certa "idéia de periferia" e fomentam uma "identidade periférica", fundada em experiências compartilhadas por moradores desses espaços. ${ }^{15}$

Tendo em vista este cenário, Frúgoli Jr. (2005) propõe que as periferias sejam compreendidas não apenas como uma espacialidade sujeita a diversos graus de segregação, mas também como um conjunto de representações nativas. Ou seja, isto requer uma compreensão que vá além da composição social objetiva destes espaços, através da qual devemos buscar reconhecer um conjunto de símbolos relacionados à noção de periferia.

Em seu trabalho, Frúgoli Jr. (2005) retoma alguns resultados da pesquisa de Guasco (2000), enfatizando o papel do rap na construção de uma narrativa de "singularização da periferia", uma vez que ele implicaria a produção e a divulgação de uma determinada representação local ou nativa. ${ }^{16}$ Guasco concebe a idéia de "periferia" divulgada pelo rap como uma "categoria nativa que não se limita a uma referência geográfico-espacial, mas descreve uma condição social que costura uma identidade entre pretos e pobres" (p. 21). Ele aponta, ainda, que "o rap é um dos maiores responsáveis pela sedimentação de uma identidade de periferia, que atualmente parece substituir num grau mais acentuado o que teria sido para outras gerações a identidade de pobre" (p. 102).

Estes movimentos também podem ser lidos segundo a proposta teórica de Bourdieu (1989), que postula a existência de uma luta simbólica dos diversos grupos pela representação legítima do mundo social. Inclui-se aí a luta simbólica pela

\footnotetext{
${ }^{15}$ Segundo Ávila (2006) "Numa dimensão cultural, as experiências de vida semelhantes vivenciadas nos locais de moradia permitiriam a formulação de uma referência básica para a constituição de uma identidade coletiva, de comportamentos e de uma produção cultural, tipicamente 'de periferia"' (p. 85).

Por outro lado, é difícil avaliar em que medida a própria produção clássica da sociologia urbana e seu modelo centro-periferia contribuiu para a cristalização desta representação sobre a periferia como um tipo singular de lugar.

${ }^{16}$ Nesta mesma linha, Nascimento (2006) aborda os discursos de escritores "marginais" que se colocam ao lado do rap como porta-vozes da periferia, referindo-se inclusive a uma "cultura da periferia".
} 
representação sobre o local de moradia por parte de agentes que empreendem ressignificações dos estigmas negativos. E o fato de haver essa luta simbólica representaria uma ressalva à assertiva de Villaça a respeito do controle das ideologias sobre o espaço urbano por parte das classes dominantes: elas podem, de fato, ter mais poder de manipulação sobre essas ideologias, mas não sem nenhuma forma de contestação.

É interessante notar que estes "novos" discursos e representações em torno da idéia de periferia, construídos a partir "de dentro", ganham maior visibilidade num mesmo momento em que as pesquisas acadêmicas começam a revelar um maior grau de heterogeneidade social destes espaços.

O atual debate sobre a distribuição dos grupos sociais no espaço urbano de São Paulo, a partir da maior disponibilidade de dados e da utilização de novas técnicas de análise, tem atribuído maior complexidade ao espaço. Primeiramente, reconhece-se a presença de classes altas na periferia - por exemplo, através da auto-segregação nos enclaves fortificados - e de favelas e bolsões de pobreza em áreas nobres (Caldeira 2000). Além disso, nas áreas periféricas, antes pensadas como homogeneamente pobres, verifica-se uma grande diversificação social, havendo distintas configurações de pobreza e de segregação, assim como melhorias na infra-estrutura urbana e maior acesso aos serviços oferecidos pelo Estado em muitas localidades. A complexidade com a qual se distribuem essas distintas configurações sociais nos espaços impõe uma revisão do modelo centro-periferia como caracterização da estrutura urbana de São Paulo, além da necessidade de falarmos em periferias, no plural, e, não mais, em uma periferia homogênea (Cf., por exemplo, Marques e Bichir 2001; Torres et al 2003; e Marques e Torres 2005).

Tendo em vista a constatação de distintas configurações da pobreza urbana, as pesquisas que compõem a coletânea de Marques e Torres (2005) afirmam o espaço como uma dimensão componente da pobreza - conformando distintas pobrezas de acordo com o território - e como um limitador das possibilidades de mobilidade social.

“(...) o território parece ser uma dimensão constitutiva da situação social em que se encontram os diversos grupos sociais na cidade, em especial para os mais pobres. Isso significa, por exemplo, que indivíduos e famílias igualmente pobres e escolarizados têm condições e características diferentes dependendo de onde morem. 
Em termos mais gerais, entendemos que, se é verdade que o mercado de trabalho continua a ocupar um papel fundamental na produção e reprodução da pobreza e das desigualdades urbanas, é também verdade que inúmeros processos locais da dinâmica das políticas públicas, e outros ligados ao cotidiano das comunidades, influenciam e diferenciam os lugares. Além disso, o próprio espaço, ao contrário de ser apenas um produto desses elementos, representa também um conjunto de constrangimentos e possibilidades, diferenciando as oportunidades que moradores de lugares mais ou menos segregados experimentam." (Marques e Torres 2005: 11-

2)

Assim, estes autores consideram o espaço como aspecto constituinte da dimensão objetiva da estratificação social. Então o espaço não apenas espelha a estratificação como também é elemento estratificador. Para além da dimensão objetiva da estratificação, o espaço é também elemento hierarquizante se considerarmos a dimensão da avaliação social. Isto pode ser depreendido das pesquisas de Pierucci (1989) e Velho (1973), por exemplo.

O artigo de Pierucci (1989) trata de um segmento da classe média cujo local de moradia (bairros da Zona Leste de São Paulo) é um traço inferiorizador do seu status, implicando em uma "autopercepção, auto-avaliação e num auto-recorte" específico com relação à classe média em geral. De maneira que este grupo rejeita a visão de mundo e o estilo de vida da classe média mais consolidada, "chique e in", distante social e geograficamente deste grupo.

Gilberto Velho, por sua vez, ao refletir sobre as representações em torno do bairro de Copacabana e de outros bairros cariocas, constata:

\footnotetext{
“uma identificação entre local de residência e prestígio social de tal forma acentuada que a simples mudança de bairro possa ser interpretada como ascensão social, mesmo não havendo alterações na ocupação ou na renda das pessoas em pauta" (Velho 1973: 89).
}

Deste modo, Velho (1973) e Pierucci (1989) mostram o quanto as diferenças espaciais podem resultar em diferenciais de estratificação entre grupos semelhantemente posicionados na estrutura social.

Por fim, gostaríamos de discorrer sobre as articulações entre hierarquias sociais e hierarquias espaciais realizadas no artigo de Agier (1990) que, ao estudar o reflexo de 
processos de mobilidade social em mobilidades espaciais, exemplifica, não apenas a teoria de Bourdieu, como também diversas outras noções discutidas neste capítulo.

Michel Agier realizou diversos estudos sobre o denominado "novo operariado baiano". Em artigo sobre este tema, o autor trata especificamente dos trabalhadores soteropolitanos que, a partir de sua entrada para as empresas do Pólo Petroquímico de Camaçari, vivenciaram um processo de mobilidade social ascendente que foi, em geral, acompanhado pela mobilidade residencial no espaço urbano de Salvador (Agier 1990).

O autor vê o "novo operariado baiano" como um grupo de status não apenas porque correspondem a um nicho profissional ao qual se imputa certa avaliação de prestígio, mas também porque o grupo se expressa na condução de um determinado estilo de vida específico, de certas práticas distintivas de consumo, nas quais se incluem as escolhas e "práticas residenciais".

Com relação às hierarquias espaciais de Salvador, é necessário considerar que, na cidade, se opõem "dois lados". O "lado da baía", voltado para a Baía de Todos os Santos é o mais antigo e desvalorizado material e simbolicamente, carrega estigmas negativos e é designado por termos como "periferia", "marginal", "bairros negros", "bairros operários". O "lado da orla", voltado para o oceano Atlântico, é mais novo e mais rico, atraindo a população em mobilidade ascendente. ${ }^{17}$

Os trabalhadores que ingressam no Pólo, em sua maior parte oriundos do "lado da baía”, freqüentemente mudam de bairro. Aqueles que obtêm cargos de alto escalão nas empresas do Pólo migram para o "lado da orla"; aqueles que obtêm cargos de baixo escalão costumam mudar para o chamado "Miolo" - área de ocupação recente na qual predominam conjuntos residenciais para a população de classe baixa ou média baixa -, com o objetivo de romper com seu meio social de origem.

\footnotetext{
"Isso sugere que a mobilidade residencial não é apenas uma mera modificação do quadro material da organização familiar, mas que é também uma expressão das necessidades objetivas de modificação dos "estilos de vida", (...). A "escolha" do novo bairro, (...) contém um aspecto simbólico e coletivo que ultrapassa as
}

\footnotetext{
${ }^{17}$ Os comentários de Agier sobre o "lado da orla" nos remetem ao texto de Bourdieu discutido acima: "As vantagens materiais de morar nesse lado da cidade são óbvias. Os ganhos simbólicos também, pelo fato de partilhar o espaço com uma população globalmente de pele mais clara e de condição econômica nitidamente melhor. Morar nesse lado significa o direito de conviver com a riqueza e de recuperar individualmente o status social globalmente associado a esse espaço urbano.” (Agier 1990: 43)
} 
"intenções" e "decisões" tomadas individualmente, acabando por configurar uma parte do status de segmento sócio-profissional analisado aqui.” (Agier 1990: 41-2)

$\mathrm{O}$ artigo, no entanto, enfoca os trabalhadores que permaneceram em seu bairro de origem - a Liberdade, no "lado da baía" - a despeito de sua ascensão social. O autor aborda as transformações vividas por estas famílias e a adoção de novas práticas distintivas - cujo referencial de "classe média" adquirido na empresa requer um distanciamento da pobreza - ao mesmo tempo em que permanecem inseridas nas práticas e nas redes de sociabilidade e de quase-familiaridade locais.

\footnotetext{
"Enquanto não existe um "lugar" social e espacial correspondente ao novo status que eles introduzem no bairro - situação que os levaria logicamente a procurar outros bairros residenciais — muitos estão fortemente inseridos no bairro enquanto "moradores". Têm afilhados nas famílias "equilibradas" e "carentes" das avenidas, participam das "turmas" do bairro e da vida associativa local. (...)

Essa inserção nas redes locais e, conseqüentemente, a identidade quase étnica que aí encontram (produto de uma socialização onde os laços pessoais permeiam a organização social) determinam as tentativas presentes de criar para suas famílias um lugar residencial próprio, (...)

Mas as suas necessidades de um novo "estilo de vida" introduzem, então, práticas inusitadas no local; comprar, reformar, e modernizar as casas com muito mais rapidez do que os outros; encher as casas de signos de status e modernidade (...), saturar a sala com móveis (...).”(Agier 1990: 57-8).
}

Assim, por um lado há o referente de pobreza do qual se quer escapar, por outro há a classe média da qual se quer aproximar. Por um lado há a "estranheza" de não existir um lugar social e espacial para eles no contexto do bairro, por outro lado estão fortemente inseridos no bairro como "moradores" e participantes das "turmas" e da vida associativa local. Por fim, o autor ressalva que nem todos os trabalhadores "têm disposições iguais para poder identificar-se com a "modernidade" da nova coletividade industrial baiana. (...) Essa confrontação de posições sociais na fábrica e no bairro atravessa a formação global da identidade social dos trabalhadores. Ela se traduz, entre outras coisas, na imobilidade residencial de mais da metade dos trabalhadores que morava no bairro da Liberdade" (Agier 1990: 59-60). 
Agier parece flagrar um momento em que se faz uma parada no meio do caminho da ascensão, que incluiria a mudança para outro bairro. Esta parada introduz uma novidade naquele contexto local.

No entanto, ficam sem resposta alguns questionamentos ao esquema teórico de Bourdieu: Esta parada no meio do caminho poderia ser explicada a partir de uma dificuldade de aquisição de um novo habitus de classe que os manteria no local de origem? Ou então, tendo em vista o peso da idéia de pertencimento àquele local, poderia ser reveladora de que, em determinados momentos ou contextos, a influência de especificidades espaciais pode superar as transformações sócio-econômicas? A primeira opção estaria dentro da proposta teórica de Bourdieu. A segunda estaria fora dos limites desta proposta, pois colocaria em relevo motivações construídas a partir de identificações ligadas a especificidades de um certo contexto local, isto é, espacial. Porém, não é improvável que a resposta seja uma combinação das duas alternativas.

De todo modo, os estudos abordados aqui nos sugerem que podemos considerar o espaço da metrópole em geral como simbolização do espaço social, como nos propõe Bourdieu, e, por exemplo, compreender a segregação dos mais pobres em espaços estigmatizados como favelas ou periferias a partir desta idéia. Mas se, por outro lado, considerarmos conteúdos sociais internos de determinados espaços, sua relação com outros espaços da cidade e com as representações que existem sobre eles, podemos então enfatizar a especificidade do espaço como variável importante na determinação dos fenômenos. Isto implica em atentar, não apenas para as diferenças entre as diversas periferias ou favelas, como também atentar para a localização de grupos igualmente posicionados na estratificação social em espaços com características distintas nas hierarquias espaciais.

Como foi apresentado na primeira parte deste capítulo, os negros das classes médias e altas podem até ter um capital econômico equivalente ao dos brancos posicionados nestes mesmos estratos, mas, de fato, não são considerados como pertencentes a esta mesma camada social. E isto deverá se refletir em sua localização no espaço urbano. Não se trataria de uma distorção na forma pela qual o espaço refletiria a estrutura social, mas, pelo contrário, evidenciaria a posição dos negros nesta estrutura. Os grupos se distanciariam no espaço urbano da mesma forma que se distanciam na estratificação social. 
Além disso, considerando que o espaço não apenas reflete a estratificação, mas também estratifica, na medida em que ajuda a promover oportunidades diferenciadas, podemos colocar a hipótese de que, por se residirem em áreas menos prestigiadas na hierarquia espacial, o local de residência (e também os estigmas que carrega) seria mais uma desvantagem que os negros das classes médias e altas acumulariam na competição com brancos destes mesmos estratos, dificultando a manutenção de sua posição social.

No entanto, os autores que citamos neste debate sobre espaço e estratificação não dão relevo à segregação por raça. Villaça, por exemplo, confere importância apenas à classe social na determinação da segregação, afirmando que "a segregação por classes subjuga, domina e explica todas as outras, além de apresentar um potencial incomparavelmente mais rico de explicação (superando as descrições) e de articulação com os processos econômico, político e ideológico" (Villaça 2004: 105).

Tendo em vista esta lacuna, trataremos, no próximo capítulo, acerca da conceituação da segregação residencial, e também de pesquisas que articulam raça e segregação nas cidades brasileiras e de abordagens teóricas (norte-americanas) sobre o tema. 


\section{Capítulo 2 - Segregação Residencial e Raça no Brasil e nos Estados Unidos}

Neste capítulo, trataremos, primeiramente, das maneiras pelas quais pode ser definido o conceito de segregação, e das perspectivas e dimensões a partir das quais este fenômeno é abordado. Em seguida, apresentaremos estudos que refletiram acerca do tema da segregação racial no Brasil e nos Estados Unidos.

\subsection{Segregação: conceitos, medidas e dimensões}

Esta seção pretende apresentar formas de se conceituar e mensurar o fenômeno da segregação residencial, indicando a maneira pela qual esta pesquisa aborda esta temática, e as dimensões que levamos em consideração. Serão referências importantes os trabalhos recentes de Eduardo Marques e Haroldo Torres que, a partir de pesquisas realizadas no âmbito do Centro de Estudos da Metrópole, têm contribuído com novas técnicas e perspectivas para a abordagem destes fenômenos na sociologia urbana brasileira.

Eduardo Marques (2005a) distingue três diferentes processos associados ao fenômeno da segregação que serão enquadrados por conceitos igualmente distintos. $\mathrm{O}$ primeiro deles corresponde à formação de guetos, cidadelas ou enclaves fortificados (Cf. Marcuse 2004) que se caracterizam pelo extremo isolamento, muitas vezes envolvendo até mesmo barreiras físicas ou legais que limitam a circulação e o acesso. Essa segregação pode ser voluntária, por exemplo, no caso de bairros formados por grupos de migrantes que cultivam seus laços comunitários ou, ainda, dos chamados “enclaves fortificados", condomínios fechados habitados por famílias de alta renda. Pode também, no entanto, ser involuntária ou forçada, no caso dos guetos judeus durante a Segunda Guerra Mundial, e dos guetos negros na África do Sul do apartheid e dos Estados Unidos de antes das conquistas dos direitos civis.

Segundo Marques (2005a):

\footnotetext{
“(...) a inexistência de dispositivos legais em nossas cidades nos leva a rejeitar já de início o conceito de gueto para caracterizar até mesmo partes de nossas periferias. Entretanto, podemos observar graus de separação que, embora não sejam tão extremos, são mesmo assim muito elevados. A questão reside no fato de que analisar
} 
graus de segregação, no sentido da separação, é bastante difícil em termos de método. Em termos conceituais, uma forma de tratar a questão seria partir da idéia de que distâncias grandes podem significar isolamento para populações de baixa renda, para as quais os custos de transporte tendem a representar uma carga dramática. O problema está em que a operacionalização dessa idéia não é nada simples, já que não existem medidas a esse respeito, nem tampouco critérios para estabelecer que deslocamentos seriam necessários considerar para determinado grupo populacional (ou que distâncias seriam grandes). Uma das soluções para o problema é tratá-lo indiretamente utilizando os dois outros sentidos de segregação, relativos à desigualdade e à separação.” (Marques 2005a: 33)

Sua segunda definição de segregação diz respeito a desigualdades de acesso, entendidas de forma ampla, podendo referir-se ao acesso a políticas públicas, a condições de vida ou à cidade, entre outros.

Neste trabalho, contudo, optaremos pela terceira concepção apresentada pelo autor, que é a adotada por ele. Trata-se da segregação como o grau de aglomeração de uma determinada categoria social em certos espaços da cidade, “(...) ou homogeneidade interna e heterogeneidade externa na distribuição dos grupos no espaço. (...) trata-se de investigar padrões de semelhança e diferença na distribuição dos grupos sociais no espaço, considerando alguma clivagem (renda, escolaridade, raça, etc.)" (Marques, 2005a, p. 34). Em suma, esta definição de segregação pode ser escrita como sendo "o grau no qual dois ou mais grupos vivem separados uns dos outros, em diferentes partes do ambiente urbano" (Massey e Denton 1988: 282).

É importante ressaltar que essa definição de segregação recai sobre o grau de concentração, no espaço, de uma categoria social com relação à outra, sendo que ambas as categorias se delimitam analiticamente. De modo que "a segregação é - sobretudo um fenômeno relacional: só existe segregação de um grupo quando outro grupo se segrega ou é segregado. É nesse componente relacional que as medidas de segregação vão se basear, buscando medir o grau de isolamento de um determinado grupo social em relação a outro.” (Torres 2004a: 42).

Os estudos recentes envolvendo o tema da segregação têm se beneficiado de uma maior disponibilidade de dados e informações sobre a realidade urbana e lançam mão de novas técnicas de análise, aplicando procedimentos de medição da segregação já comuns na produção norte-americana sobre o tema, mas que ainda não haviam sido 
utilizados no Brasil. ${ }^{18}$ Tais técnicas possibilitaram revelar a heterogeneidade $\mathrm{e}$ complexidade da estruturação espacial das metrópoles com maior acuidade.

Para mensurar a segregação, o procedimento mais utilizado é o índice de dissimilaridade, que mede a uniformidade de distribuição de um dado grupo social no espaço, com relação a outro. O valor do índice indica a proporção de membros de um dado grupo social que teriam que mudar-se das áreas que residem para que a distribuição de cada grupo no espaço urbano se torne uniforme de acordo com sua participação na população total da cidade.

Neste texto, não apenas veremos exemplos de aplicação do índice de dissimilaridade, mas também exploraremos diversos outros procedimentos para mensuração da segregação, aplicando-os para medir a segregação por raça e classe na cidade de São Paulo.

Novamente com relação à definição de segregação aqui adotada, de acordo com Sabatini, Cáceres e Cerda (2004) e Sabatini e Sierralta (2006), distinguem-se três dimensões de análise da segregação: duas objetivas e uma subjetiva.

As duas dimensões objetivas são identificadas também por Torres (2004a): por um lado, a tendência de grupos sociais se concentrarem em certas áreas específicas da cidade, e, por outro, o grau de homogeneidade social interna a determinadas áreas.

\begin{abstract}
"Enquanto a primeira trata o grau da concentração ou a dispersão de cada grupo na cidade, a segunda examina cada área, em termos da homogeneidade ou heterogeneidade social que a caracteriza. A primeira analisa grupos sociais em termos de sua posição espacial, e a segunda, as áreas da cidade com relação a sua composição social. Parecem duas formas de visualização do mesmo fenômeno. Contudo, cada qual capta um atributo diferente da segregação social do espaço, atributos cujos efeitos, de resto, têm sinais bem distintos." (Sabatini e Sierralta 2006:
\end{abstract} 171.)

Um exemplo da diferença entre as dimensões é dado em Sabatini et al. (2004), e versa sobre "os cones de alta renda" nas principais cidades chilenas, onde se verificam a tendência de concentração das famílias de elite. Segundo os autores, quase a totalidade

\footnotetext{
${ }^{18}$ A única exceção parece ser o trabalho de Edward Telles (Cf. Torres 2004a, p 41, nota 1) que, na década de 1990, realizou medições da segregação residencial com base na cor da pele dos moradores das metrópoles brasileiras. Sendo esta, talvez, a primeira aplicação de índices de segregação no Brasil. Voltaremos a abordar estas questões mais adiante.
} 
das elites se concentra nestes “cones" geográficos (primeira dimensão). Porém, estas áreas também eram compartilhadas por grupos das classes médias e baixas, havendo, então, pouca homogeneidade social (segunda dimensão). Portanto, deveríamos distinguir o alto grau de segregação das elites - ou seja, sua concentração em uma única zona da cidade - da baixa segregação residencial daquela área - que se deve à grande diversidade social que apresenta.

A distinção entre duas dimensões em sua definição para o tema evidencia que a noção de segregação desses autores implica a possibilidade de uma abordagem centrada nos grupos sociais e que se dê, também, a partir de determinados espaços.

Pontuamos, então, que uma área é segregada por apresentar alto grau de homogeneidade social, e um grupo é segregado por se concentrar mais em certas áreas. Levando sempre em consideração que os grupos e os espaços são delimitados analiticamente, uns com relação aos outros. No limite, todas as áreas e grupos podem ser considerados segregados ou misturados, dependendo do recorte analítico utilizado.

No entanto, falar em "grupo segregado" e "espaço segregado" pode ser fonte de confusão ou, ao menos, de ambigüidade. Afinal, é muito comum na literatura sobre segregação que o adjetivo "segregado" apareça sem que se especifique se ele se refere a um grupo ou a um espaço, podendo essa referência estar, inclusive, subentendia. Este é o caso de termos que definem certas áreas (como: periferia, gueto ou condomínio), e que já indicam o grupo que se segrega nelas.

Ademais, no interior de estudos que tratam de "grupos segregados" é bastante comum que os autores não deixem claro que o adjetivo "segregado" advém da distribuição do grupo em questão com relação a algum outro. $\mathrm{O}$ foco deste trabalho a demonstração da segregação entre grupos: entre negros e brancos, e entre negros e brancos nas camadas sociais mais altas. Mas faremos constantes referências aos espaços onde estes grupos estão concentrados.

Assim, quando tratamos de periferias, tratamos de espaços com alta concentração de pobres, ou seja, um espaço segregado do ponto de vista do grau de homogeneidade de pobres. Entretanto, do ponto de vista racial, de modo geral, as periferias são espaços de grande mistura, não sendo, portanto, espaços segregados em relação a esse fator. Ao passo que as áreas de elite são espaços segregados tanto social quanto racialmente, uma vez que apresentam maior grau de homogeneidade tanto de brancos quanto de ricos. 
Já no que tange à segregação com referência aos grupos, mostraremos que existe segregação do ponto de vista racial nas faixas de renda mais altas, porque os negros de classe média têm maiores concentrações em espaços diferentes se comparados aos brancos do mesmo estrato. Em outras palavras, estamos tratando de padrões distintos de distribuição destes grupos no espaço urbano. De maneira que não são apenas os negros ou apenas os brancos de classe média estão segregados, mas pode-se afirmar - existe segregação de um grupo com relação ao outro, o que equivale a dizer que ambos se segregam.

Telles (1993), ao calcular o índice de dissimilaridade entre os grupos de cor, visa saber em que medida um grupo se segrega com relação a outro. Em geral, é essa perspectiva (dos grupos) que pode ser contemplada a partir do índice de dissimilaridade.

Ainda com relação às dimensões subjacentes ao conceito de segregação aqui discutido, Sabatini et al. (2004) assinalam uma terceira dimensão: a percepção subjetiva que os moradores têm da segregação objetiva. Os autores destacam que os efeitos de desintegração social causados pela alta segregação da população pobre têm como uma de suas causas o sentimento de marginalidade por parte dos moradores destes espaços. Devemos enfatizar o fato de que esta percepção encontra-se mediada por determinados símbolos, discursos e representações que são associadas aos espaços segregados.

Posto isto, podemos refletir sobre os espaços segregados a partir de duas perspectivas: por um lado, através de características objetivas reveladas por meio de dados empíricos, em geral, censitários; por outro lado, através das representações que podem ser disseminadas por discursos que abordam tais espaços e que contribuem para cristalizar (ou ressignificar) estigmas sobre estes espaços.

A consideração das dimensões objetivas e subjetiva nos sugere duas perspectivas a partir das quais os estudos contemplam o espaço: a partir da caracterização de grupos que se segregam em determinados espaços e a partir das representações que se constroem sobre estes espaços. Estas duas perspectivas subjazem não apenas as abordagens sobre as periferias urbanas - objeto privilegiado dos estudos brasileiros sobre segregação, como vimos no capítulo anterior - mas também as pesquisas que propõem uma articulação entre raça e espaço urbano - que, em certa medida, também propõem uma reflexão sobre as periferias, seja como espaço onde a população negra encontra-se sobre-representada, seja através de estigmas negativos ou afirmações de 
pertencimento que mobilizam representações que associam estes espaços à população negra. Veremos mais detalhes sobre este segundo grupo de pesquisas na próxima seção.

\subsection{Raça e segregação no Brasil}

A bibliografia que articula raça e segregação residencial no Brasil é pouco extensa. ${ }^{19}$ Entretanto, os estudos existentes fazem referência às duas dimensões abordadas na seção anterior: a da segregação objetiva e a dos símbolos e representações relacionados a espaços segregados, que permitem a elaboração de discursos identitários. Considerando estas dimensões, podemos identificar, no conjunto das pesquisas já realizadas, a existência de dois grupos: por um lado, o dos estudos qualitativos, que giram em torno dos aspectos simbólicos e questões identitárias que dizem respeito à relação "raça-espaço urbano"; e, por outro, o grupo dos estudos quantitativos, que incidem sobre a questão da segregação com base na cor da pele a partir da análise de dados censitários. Estudemos agora, pois, com maior detalhe o que aporta para a nossa discussão cada um desses dois grupos.

Com relação ao primeiro deles, podemos dizer que seus autores, ao proporem uma reflexão sobre raça e espaço urbano, tomam como objeto de pesquisa favelas e bairros periféricos, lançando mão de noções como "territórios negros" ou "espaços racializados", para trabalhar as idéias de que lugares com alta concentração de negros proporcionam uma sociabilidade menos problemática para eles, e de que estigmas atribuídos ao negro estão também associados às representações de determinados espaços da cidade, podendo ser ressignificados na forma de discursos identitários. Atentemos, contudo, à particularidade desses estudos.

O artigo “Territórios Negros nas Cidades Brasileiras”, de Raquel Rolnik (1989) parece ser um marco deste grupo, haja vista que quase todos os trabalhos posteriores fazem referência a ele. Nele, a autora faz um levantamento histórico da inserção territorial do negro no Rio de Janeiro e em São Paulo. Ao delinear esse quadro, a autora apresenta a noção de "território negro" como um espaço com história e tradições próprias, além de ser marcado por um estigma de marginalidade e desorganização

\footnotetext{
${ }^{19}$ Rolnik (1989) diz que "o tema empírico do negro nas cidades até agora foi pouco explorado nos textos empíricos da sociologia do negro ou das cidades" (p.29). Dezesseis anos depois, a mesma carência é enfatizada por Vargas, que aponta o "silencio acadêmico em torno de raça e espaço urbano" (2005: 98).
} 
associado à população negra. Tais territórios nunca foram, entretanto, exclusivamente negros, visto que lá residiam também diversos outros grupos das camadas populares. Não obstante, abrigavam "comunidades afro-brasileiras fortemente estruturadas" (Rolnik 1989: 35), haja vista que a maioria das organizações negras como escolas de samba, terreiros, clubes, movimentos sociais, etc. estão historicamente localizadas em bairros habitados por uma proporção de negros acima da média das respectivas cidades. $^{20}$

Carril (2003), por sua vez, recorre à noção de "território negro" de Rolnik ao estudar o bairro do Capão Redondo, em São Paulo, enfatizando a grande presença de afro-descendentes nesses espaços de exclusão social. Um outro dado que chama atenção no trabalho de Carril é o fato da autora abordar o papel do rap na construção de um discurso que traz a idéia de uma identidade negra fundada sobre um território - a periferia -, construindo, assim, um paralelo com a identidade quilombola.

Já Silva (2004) discorre sobre as diferentes experiências de sociabilidade de negros de acordo com os bairros onde residem, sejam eles vizinhanças de classe média ou bairros periféricos. Ela mostra que mesmo os que possuíam poder aquisitivo de classe média e moravam em "bairros incluídos" sentiam-se hostilizados por ocuparem um lugar que não fora destinado ao negro. Retomando a mesma noção de "território negro", a autora trata, então, de bairros que, apesar de marginalizados, eram mais propícios ao encontro e à sociabilidade da população negra.

O artigo de Vargas (2005) analisa a cobertura da imprensa escrita a respeito do caso do "condomínio-favela" no Jacarezinho (Rio de Janeiro) e elabora a noção de "espaços racializados" para referir-se a representações que associam negritude e favela e permeiam o senso comum, construídas e consolidadas com o auxílio da mídia. O autor chama atenção para a necessidade de estudos que avaliem como certas noções de espaço urbano estão ligadas a entendimentos sobre raça, na medida em que se espera que certas áreas correspondam a determinados grupos raciais. "Daí a percepção comum no Brasil de que, se uma pessoa é moradora de favela, ele ou ela deve ser não-branco/a." (Vargas, 2005, p. 102)

O trabalho de Ney Oliveira (1996) reflete, a partir de um estudo comparativo entre guetos novaiorquinos e favelas cariocas, como os padrões de ocupação do espaço

20 Rolnik também nos apresenta dados que informam que os negros não estão uniformemente distribuídos nas periferias paulistanas, mas se concentram em núcleos que já eram "territórios negros" desde pelo menos a década de 1930. 
urbano estão ligados a grupos raciais, destacando o fato de que a população negra está desproporcionalmente representada nas áreas pobres e desprovidas de equipamentos públicos. Para o autor, esse padrão de estabelecimento tem ajudado a consolidar identidades raciais em torno das movimentações políticas por melhorias de infraestrutura.

Com relação à abordagem da segregação residencial com base em raça no Brasil - o segundo grupo aqui definido -, localizamos suas primeiras manifestações nos clássicos da sociologia das relações raciais, como o trabalho de Donald Pierson (1971 [1942]) em Salvador, de Fernando Henrique Cardoso e Octávio Ianni (1960) em Florianópolis, e o estudo de Costa Pinto (1998 [1953]) sobre o negro no Rio de Janeiro. Este último autor chega à seguinte conclusão, condizendo com os resultados dos outros dois trabalhos citados:

\footnotetext{
"Da análise do padrão ecológico resultou evidente a concentração dos elementos de cor da população do Rio de Janeiro nas camadas mais pobres da sociedade e, por conseqüência, a concentração desses grupos étnicos nas zonas de moradia em que aquelas classes predominam" (Pinto 1998 [1953])
}

Desta forma, segundo a abordagem dos autores clássicos apontados, a segregação espacial entre negros e brancos era fortemente condicionada pela classe social. $^{21}$

Entretanto, somente décadas depois, nos estudos de Edward Telles (1993; 1995; 1996; 2003), é que este tema ganha um tratamento mais sistemático, através da utilização de dados censitários.

Telles publicou, na década de 1990, uma série de artigos, nos quais analisava o peso da variável cor da pele nos índices de segregação residencial em 35 regiões metropolitanas do Sul, Sudeste e Nordeste do Brasil, a partir dos dados do Censo demográfico brasileiro de 1980. Para medir a segregação foi utilizado o índice de dissimilaridade, que mede a uniformidade de distribuição de grupos sociais no espaço.

De acordo com os índices obtidos então, considerou-se a segregação racial por residência no Brasil como sendo moderada, se comparada aos padrões extremos encontrados nos Estados Unidos. No entanto, para verificar até que ponto a segregação

\footnotetext{
${ }^{21}$ Estes estudos abordaram a segregação espacial ou distribuição dos grupos no espaço urbano a partir da idéia de ecologia social, procedente da Escola de Chicago de Sociologia.
} 
residencial por raça ou cor no Brasil estaria ou não determinada pela variável classe social, Telles separou a população das metrópoles em faixas de renda e calculou os índices de segregação dentro de cada uma delas. ${ }^{22}$ Observou, assim, que os índices cresciam à medida que crescia, também, o nível de renda. Desse modo, Telles concluiu que:

\begin{abstract}
“Os resultados mostram que a segregação residencial entre os diversos grupos de cor não pode ser explicada pelo status sócio-econômico (posição defendida na literatura sobre o tema), porque a segregação residencial moderada por cor ocorre entre membros de uma mesma faixa de renda. Além disso, os níveis de segregação aumentam junto com a renda naquelas áreas metropolitanas com um número substancial de brancos, negros e mulatos nas respectivas categorias de renda. Assim, a classe média afro-brasileira é mais dessemelhante espacialmente em relação aos brancos de classe média do que os afro-brasileiros pobres em relação aos brancos pobres. Entretanto, para a classe média branca na maioria das áreas metropolitanas, a simples ausência de uma classe média significativa de origem africana garante que os bairros de classe média permaneçam como predominantemente brancos. A segregação relativamente limitada por cor entre a grande população pobre sugere que as opções habitacionais extremamente limitadas tornam a questão cromática pouco prioritária na escolha do lugar da residência.” (Telles 1993: 16)
\end{abstract}

A partir da publicação dos trabalhos de Telles, surgiram outros estudos propondo uma abordagem quantitativa da segregação por raça/cor nas metrópoles brasileiras.

Torres (2005) calculou o mesmo índice de dissimilaridade entre brancos, pretos e pardos na região metropolitana de São Paulo, com base em dados da amostra do Censo de $2000 .^{23}$ Os resultados dos indicadores relativos à cor da pele foram comparados ao índice de dissimilaridade por classe, que se revelaram muito mais fortes. Em face destes dados, Torres (2005) dirá que:

\footnotetext{
${ }^{22}$ Haja vista pesquisas clássicas sobre relações raciais no Brasil, que deram ênfase ao tema ascensão social dos negros como campo fecundo para distinguir o "preconceito de classe" do "preconceito de cor" (por exemplo: Azevedo 1996; Bastide e Fernandes 1959; Fernandes 1978).

${ }^{23} \mathrm{O}$ índice entre brancos e pretos resultou em $23,66 \%$, ao passo que entre brancos e pardos em $29,21 \%$ e, entre pretos e pardos em 16,44\% - todos índices muito suaves. Contrasta com estes índices entre os grupos de cor o alto índice de $68 \%$ calculado para a população total das faixas de renda de 0 a 3 saláriosmínimos com relação a população na faixa de mais de 20 salários-mínimos (Torres 2005). Maiores informações sobre o cálculo e a interpretação do índice de dissimilaridade podem ser encontradas no capítulo 3.
} 
"Em síntese, os resultados aqui apresentados indicam a existência de segregação em São Paulo, caracterizada sobretudo como uma segregação orientada pelo componente socioeconômico, mas não necessariamente pelo racial. Tal resultado é consistente com o esperado pela literatura." (p. 91).

Outros pesquisadores realizaram o estudo da segregação entre brancos e negros através do que Pretecéille (2004) chamou de "análise tipológica". Destacaremos aqui os trabalhos de Costa e Ribeiro (2004), sobre a Região Metropolitana de Belo Horizonte; Ribeiro (2007), sobre a Região Metropolitana do Rio de Janeiro; Garcia (2006) sobre o Rio de Janeiro e Salvador; e Carvalho e Barreto (2007), sobre Salvador.

Estes trabalhos adotaram um procedimento semelhante. Primeiro, classificaram as áreas que compõem as cidades ou Regiões Metropolitanas analisadas a partir de uma tipologia hierarquizada segundo os perfis sócio-econômicos predominantes. Assim, uma área com maior concentração da população de mais alta renda e escolaridade será, por exemplo, classificada como "superior", as áreas com menores rendas e escolaridades como "inferiores", etc. Em seguida, comparam a proporção de negros e brancos em cada uma dessas áreas, concluindo que, apesar de não haver segregação absoluta, as áreas superiores apresentam concentração de brancos acima da média enquanto as áreas inferiores, maior concentração de negros. Além disso, concluem que a concentração da população negra nas áreas mais pobres e degradadas pode contribuir para a reprodução das desigualdades, na medida em que implica prejuízos simbólicos e dificulta o acesso ao mercado de trabalho e a maiores possibilidades de ascensão sócio-econômica.

Carvalho e Barreto (2004), além de terem realizado uma "análise tipológica", também calcularam o índice de dissimilaridade entre negros e brancos em Salvador ${ }^{24}$. A respeito dos resultados obtidos, as autoras argumentam que:

\footnotetext{
"Como a posição na estrutura social e a apropriação do espaço urbano são estreitamente articuladas, o território metropolitano termina por também assumir as feições dadas pelas características de raça/cor de sua população. (...) Além disso, os dados do Censo deixam evidente que as articulações entre raça/cor e ocupação também se refletem nos padrões de apropriação do espaço urbano, como seria de esperar, contribuindo para a segregação racial. Informações relativas à composição racial dos diferentes tipos de áreas encontradas em Salvador mostram como os brancos se
}

\footnotetext{
${ }^{24}$ Que resultou no valor de 0,30155 (Carvalho e Barreto 2004).
} 
concentram nas áreas de tipo superior e médio superior, enquanto os negros predominam, principalmente, nas de caráter popular e popular inferior.” (p.259)

É preciso lembrar, no entanto, que os padrões encontrados por esses estudos realizados depois dos de Telles são semelhantes aos delineados pelos estudos clássicos nos anos de 1950 e 60. Ainda que estes estudos recentes não explicitem os mesmos argumentos de Costa Pinto reproduzidos no início desta seção, também não apresentam argumentos que contestem a tese de que a maior concentração de negros nas áreas pobres explicar-se-ia por sua maior concentração entre os pobres.

Há, entretanto, duas dificuldades não resolvidas nestas pesquisas recentes que já haviam sido apontadas no trabalho de Costa Pinto (1998 [1953]): a existência de empregadas/os domésticas/os negras/os que moram nas residências onde trabalham, localizadas em bairros ricos; e o fato de muitas favelas com grande população negra se localizarem em vizinhanças ricas. Acrescenta-se a isso as novas complicações trazidas pelo padrão mais complexo de segregação, no qual surgem, por exemplo, enclaves ricos em periferias.

Tais complexidades tornam, desde o nosso ponto de vista, insuficiente uma análise que opere apenas através da comparação da proporção de negros e brancos em cada bairro, pois, dada a heterogeneidade de composição das diversas áreas da cidade, não é possível determinar, por exemplo, se a percentagem de negros nos bairros ricos é composta por negros ricos ou por negros pobres, assim como tampouco podemos distinguir em que medida a segregação por raça seria apenas um epifenômeno da segregação por classe social.

Uma possível solução para esse problema metodológico seria, justamente, aquela já apresentada por Telles: separar a população em faixas de renda e medir a segregação entre os indivíduos brancos e negros que ocupam o mesmo estrato social. ${ }^{25}$ Afinal, separar os grupos raciais em estratos de renda, além de ser um bom modo de identificar o componente propriamente racial da segregação, nos permite também

\footnotetext{
${ }^{25}$ Este tipo de estratégia foi empregada por Rios Neto (2005). Este autor, a partir dos dados do Censo de 2000 para o município de Belo Horizonte, calculou índices de segregação entre negros e brancos de dentro de faixas de renda e de escolaridade, chegando a conclusões condizentes com as de Edward Telles: "Percebe-se que a segregação racial aumenta nos grupos mais favorecidos, ou seja, com escolaridade e renda per capita maiores. (...) Dessa forma, não se pode considerar que apenas os fatores socioeconômicos são os responsáveis pela segregação residencial em Belo Horizonte: fatores como autosegregação e racismo também têm que ser levados em consideração." (Rios Neto 2005: 11). No entanto, o autor se furta em realizar uma análise mais ampla sobre estes achados.
} 
complexificar a comparação entre negros e brancos, através da abordagem estratificada destes grupos.

Considerando que nos parece profícua, esta será a trilha seguida por este trabalho. No capítulo 3 empregaremos distintas técnicas de mensuração com o objetivo de descrever os graus de segregação entre negros e brancos das mesmas faixas de renda. Cabe enfatizar que o intuito aqui não é o de refutar a predominância da classe social na determinação da segregação, mas o de evidenciar as especificidades raciais deste fenômeno, dado que Telles já demonstrara que a raça é uma variável não desprezível.

Se, no Brasil, este tipo de perspectiva sobre a segregação foi pouco cultivada, nos Estados Unidos, ela é matéria de uma vasta bibliografia sociológica. Na seção seguinte discorreremos sobre o tema da segregação residencial por raça nos Estados Unidos, enfocando o debate a respeito da importância das variáveis de status sócioeconômico e da pertença étnico-racial na determinação deste fenômeno.

\subsection{Segregação Residencial na Abordagem norte-americana}

A literatura estadunidense apresenta a mais volumosa e tradicional produção de estudos sobre segregação, temática cultivada desde a institucionalização da sociologia neste país pela Escola Sociológica de Chicago, que tinha como foco o estudo de fenômenos e problemas urbanos candentes na primeira metade do século XX. Dentre as questões em pauta, destaco aqui as ondas migratórias de diversas etnias e nacionalidades, de populações rurais e de negros do sul do país para as metrópoles do norte que, então, apresentavam crescimento sem precedentes. Estes grupos se estabeleceriam em territórios homogêneos da Chicago e de outras metrópoles norteamericanas, formando os chamados slums, Chinatowns, Little Italys, Deutschlands, Black Belts, Latin Quarters etc.

Assim, a presença dessas questões na agenda dos problemas urbanos contribuiu para que, nos Estados Unidos, se constituísse uma tradição de estudos da segregação racial e de minorias étnicas e de imigrantes, os quais tomam como objetos principais os guetos negros e os enclaves étnicos. O grau de segregação era tomado como uma medida de "distância social" entre os grupos e, principalmente, entre esses grupos e a sociedade mainstream, sendo interpretada como um dos principais indicadores do 
processo de assimilação destes grupos pela sociedade urbana norte-americana. Retomaremos este ponto logo abaixo.

Embora a segregação seja um fenômeno que atingiu a todos os grupos minoritários nas cidades estadunidenses, com relação aos negros ela adquiriu características muito mais severas. No que diz respeito aos guetos negros especificamente, é um atributo particular seu o confinamento involuntário, quase total e que se reproduzia por várias gerações. Gozando de amparo legal, esta segregação espraiou-se para as escolas, empregos, serviços públicos e representação política, desenvolvendo, deste modo, uma estrutura social paralela. (Wacquant 1994: 105).

De acordo com Massey e Denton (1993), antes do início do século XX, com os grandes fluxos migratórios de negros para as cidades que se industrializavam do norte do país, não havia segregação racial nas cidades norte-americanas. O crescimento da população negra nestas cidades despertou grande hostilidade e alarme por parte dos brancos, que eram intolerantes com vizinhos de cor, e temiam uma "invasão" negra. Isto resultou num forte aumento de atitudes racistas, culminando na ocorrência de ondas de violência racial.

Assim, negros que moravam ou que apenas transitavam por bairros que não eram reconhecidos como sendo "lugar de negros" eram violentamente atacados e chegavam a ter suas residências queimadas. A partir da ocorrência destas ondas de ataques, os negros passaram a ser separados dos brancos por linhas de cor no emprego, na educação e na moradia. Negros vivendo fora de áreas reconhecidas como negras eram forçados a mudar para os guetos, que, desde então, iniciaram um contínuo processo de expansão.

A partir da década de 1920, os brancos de classes mais altas buscaram formas menos violentas de manter os negros afastados: formavam associações de melhoramentos de bairros que preveniam a entrada de negros, com os argumentos de que visavam promover a segurança da vizinhança e evitar a desvalorização das propriedades. Estas associações faziam uma série de documentos, pactos e compromissos para evitar a presença de negros em seus bairros, inclusive pressionando imobiliárias, comerciantes e proprietários de imóveis a não negociar com negros.

Aos poucos, proliferavam mercados imobiliários racialmente segmentados nas cidades. Com o grande afluxo de negros para as pequenas áreas urbanas dos guetos, os preços dos imóveis nestas áreas disparavam. Isso fomentou o interesse do capital 
imobiliário na criação de áreas urbanas para negros, pois, na medida em que haviam valores diferenciados de áreas brancas e áreas negras, podiam auferir maiores lucros.

Este processo de guetização foi ainda reforçado por ações governamentais. Os programas de financiamento não aceitavam imóveis em bairros ocupados por minorias. Além disso, as ações públicas municipais promoviam processos de "renovação urbana" em áreas de guetos próximos a bairros brancos, transferindo os negros destas áreas para conjuntos habitacionais localizados em outros locais mais distantes, mas com alta densidade de negros.

Na década de 1960, respondendo às reivindicações dos movimentos por direitos civis, o governo norte-americano sancionou diversas leis contra a discriminação e contra a segregação. No entanto, apesar da vigência de legislação contra a discriminação, da maior tolerância racial e do crescimento da classe média negra, que iniciou um movimento de mudança para fora dos guetos das áreas centrais das cidades, até hoje, a segregação racial vem diminuindo muito lentamente, conforme nos mostram os dados dos trabalhos de Massey e Denton (1987; 1993), Charles (2003) e de Iceland e Wilkes (2006).

Wacquant (1994) aponta ainda que os guetos das áreas centrais das grandes cidades converteram-se nos chamados "hiperguetos", apresentando níveis assustadores de degradação física, violência, exclusão econômica e dificuldade social.

Atualmente, tendo em vista a continuidade das ondas migratórias em direção aos Estados Unidos, está em pauta o crescimento dos índices de segregação de hispânicos e, em menor grau, de asiáticos (Charles 2003; Iceland e Wilkes 2006) - como já esteve a de italianos, poloneses, judeus, etc no início do século $\mathrm{XX}-$, mas a de negros continua a ser a mais forte e persistente. Além disso, é notável o fato de que os índices de segregação dos hispânicos negros se aproximam mais dos afro-americanos do que dos outros hispânicos.

Nenhum outro grupo étnico ou racial teve uma experiência de guetização como a dos negros na história dos EUA. Para Massey e Denton (1993), a segregação é um dos arranjos institucionais fundamentais que mantêm a subordinação dos negros na sociedade dos Estados Unidos.

Há diversas tentativas de explicação destas tendências de segregação que interrelacionam as questões étnico-raciais com as questões de classe. Neste campo, há duas abordagens teóricas principais: o modelo spatial assimilation [assimilação espacial] e o 
modelo place-stratification [estratificação de lugares]. O primeiro põe ênfase nas diferenças grupais de classe social, enquanto segundo enfatiza a persistência do preconceito e da discriminação.

A assimilação espacial é uma concepção mais tradicional, originária das teorias da escola de Chicago. Como vimos acima, na primeira metade do século $\mathrm{XX}$, os teóricos da Escola de Chicago estavam preocupados com o fato de os grupos de imigrantes e de negros se estabelecerem em guetos e enclaves de composição étnicoracial homogênea e com as possibilidades de integração e de aculturação com a maioria de brancos e à cultura mainstream.

Segundo estes pensadores, a separação entre os grupos étnicos ocorreria, primeiramente, com base na língua e na cultura. Entretanto, haveria uma tendência de, com o passar do tempo e com a integração econômica e cultural, estes laços comunitários enfraquecerem, implicando na assimilação destes grupos minoritários à sociedade abrangente. Esta assimilação seria também espacial, uma vez que os indivíduos que obtivessem sucesso sócio-econômico tenderiam a mudar-se para fora dos enclaves homogêneos, passando a residir mais perto do grupo majoritário. De maneira geral, a segregação refletiria as diferenças grupais de recursos materiais e preferências culturais ou comunitárias (Cf. Massey 1981; Logan, Alba e Leung 1996).

Deste modo, um dos postulados da teoria ecológica da escola de Chicago, que orienta o modelo da assimilação espacial, é o de que o avanço sócio-econômico dos grupos étnico-raciais minoritários levaria a sua integração com a sociedade abrangente e a diminuição da segregação. Haveria, portanto uma relação inversa entre status sócioeconômico e segregação residencial dos grupos étnico-raciais. E os indivíduos tenderiam a converter ganhos sócio-econômicos em mudanças residenciais para localizações de melhor qualidade.

\footnotetext{
"Esse processo implica, por um lado, em uma tendência para a dispersão dos membros do grupo minoritário, abrindo o caminho para maior contato com os membros da maioria étnica (...) E, por outro lado, em maior semelhança nas características residenciais entre os membros bem-sucedidos do grupo minoritário e seus pares da maioria" (Alba e Logan 1991: 433).
}

Assim, o fato de negros e hispânicos, por exemplo, estarem majoritariamente representados nas classes mais baixas leva à conclusão fácil de que a segregação por 
raça nos Estados Unidos seria apenas um resultado lógico das diferenças de classe e de estilo de vida. De modo geral, os índices de segregação de fato diminuem conforme os grupos minoritários apresentam melhorias sócio-econômicas e conforme passam as gerações de imigrantes. Apresentando, assim, grande consistência com o modelo da assimilação espacial, principalmente para os grupos hispânicos e asiáticos. Entretanto, o modelo parece não funcionar tão bem para os afro-americanos e hispânicos negros que, conforme ascendem socialmente, obtêm ganhos de localização bem menores que os dos brancos e dos outros grupos étnicos. Assim, para os norte-americanos de ascendência africana, as diferenças de classe social são apenas parte da explicação para a segregação residencial (Cf. Charles 2003). De acordo com Logan, Alba e Leung (1996), para os defensores do modelo da spatial assimilation, a segregação dos negros ou trata-se de um caso excepcional ou é vista como parte de uma transição.

A persistência da segregação entre negros e brancos, independentemente da classe social, corrobora o modelo place-stratification. Esta perspectiva enfatiza o efeito do preconceito e da discriminação para a manutenção da segregação residencial, limitando a possibilidade dos negros, mesmo em ascensão, de residirem nos mesmos bairros que brancos de mesma classe social. A principal idéia que sustenta este modelo é a de que as distribuições residenciais estão relacionadas à posição relativa dos grupos nas hierarquias sociais. Como a desigualdade racial é parte da estrutura social, mesmo que obtenham ascensão social e renda semelhante, os negros estão abaixo dos brancos nas hierarquias de status, e isto se reflete nas localizações espaciais. Os brancos preservam suas vantagens de status relativo, mantendo a distância social dos outros grupos, através da segregação. (Cf. Charles 2003, Iceland e Wilkes 2006)

O modelo place-stratification deriva da teoria de Logan (1978), que tem como pressupostos: a) que existe uma estratificação de lugares; b) que a desigualdade entre os lugares é uma dimensão da estratificação de pessoas; c) que estes lugares estratificados são base para ação coletiva dos indivíduos a eles vinculados. Os lugares são, então, tomados como atores coletivos em uma "competição de lugares", que pode render ganhos de estratificação social para os indivíduos vinculados aos respectivos lugares. ${ }^{26}$

A diferenciação de lugares implica em vantagens ou desvantagens para as pessoas ligadas a eles, por isso ocorrem esforços coletivos e ações políticas nas quais as

\footnotetext{
${ }^{26}$ A noção de "competição de lugares", bem como a teoria de Logan (1978) de modo geral, se aplica a lugares de diferentes níveis geopolíticos: bairros, cidades, regiões, países.
} 
pessoas agem coletivamente visando obter ganhos para os seus lugares nesta "competição de lugares", criando, assim, desigualdades entre os lugares. Como os ganhos para os lugares se convertem em ganhos para as próprias pessoas vinculadas a eles, a competição entre lugares acaba por reforçar a estratificação social existente, pois as vantagens iniciais tendem a redundar em manutenção das vantagens.

Com relação à segregação, Logan (1978) diz que:

\footnotetext{
"A segregação residencial cria uma hierarquia de status dos bairros definida simplesmente pelas características dos seus residentes, ao mesmo tempo em que a classe ou o status em comum se torna um símbolo através do qual as pessoas identificam sua área física como uma comunidade. A hierarquia de status de lugares é reforçada por decisões individuais das pessoas de traduzir a ascensão social em mudança de local de residência.” (p. 407)
}

Para este autor, as ações de oposição à integração racial que descrevemos acima - como os atos de violência contra pioneiros de uma minoria em um bairro, os acordos de associações de bairros visando evitar a entrada de negros, os mercados imobiliários racialmente segmentados, as pressões por ações governamentais que reforçam a segregação etc. - são exemplos extremos de ações coletivas que tem como base o local de residência e que visam defender reivindicações de status dos indivíduos que lá habitam.

Apesar de estas ações consistirem em evidências do papel da discriminação para a constituição da segregação residencial, ocorrem algumas controvérsias empíricas no campo da place-stratification. Vários estudos discutem em que medida a segregação seria de fato uma questão racial, distinta de questões de classe (Cf. Charles 2003).

Para alguns autores, os indivíduos tendem a preferir morar próximo a outras pessoas do mesmo grupo étnico ou racial por uma simples questão de etnocentrismo, comum em todo tipo de grupo social. Entretanto, estudos sobre preferências residenciais mostraram que os brancos têm maior preferência por ter vizinhos da mesma raça. No caso dos negros, a preferência por ter vizinhos do mesmo grupo étnico-racial é a mais fraca de todos os grupos pesquisados. Por outro lado, os brancos são os vizinhos mais desejáveis para todos os grupos étnico-raciais, e os negros os vizinhos menos desejáveis. Além disso, os negros manifestam grande receio de sofrer hostilidade em bairros majoritariamente brancos. 
Para a corrente denominada por Charles (2003) como "proxy racial", uma série de estereótipos negativos sobre os negros estão associados a características indesejáveis de classe social, e dominam representações sobre bairros de maior concentração de negros. Ou seja, os mesmos estereótipos negativos incidiriam sobre os negros, sobre os pobres e sobre determinados bairros, fazendo com que estes bairros sejam evitados e com que os negros sejam pouco desejáveis como vizinhos.

\footnotetext{
"De acordo com a proxy racial (...) e com a hipótese de estereótipos de base racial sobre os bairros (...), é a coleção de características indesejáveis de classe social associadas com os negros ou com os bairros onde se concentram - o desemprego , a dependência social, a propensão ao comportamento criminoso - não a raça por si só, que motiva a aversão a vizinhos negros, não apenas entre o out-groups [não negros], mas também entre os próprios negros. Ainda assim, a raça é central para cada uma dessas alternativas, e as avaliações diretas do papel do preconceito frequentemente incluem uma ou mais destas explicações alternativas." (Charles 2003: 182)
}

Todavia, estas correntes não contradizem o argumento principal da placestratification: de que as hierarquias da estrutura social se refletem nas localizações residenciais, orientando preferências de moradia, e de que o racismo exerce papel ativo na determinação da segregação.

$\mathrm{Na}$ verdade, os modelos spatial assimilation e place-stratification não são necessariamente antagônicos, podendo servir para explicar distintos padrões de segregação. Mas, para este trabalho, o modelo place-stratification será uma importante referência, uma vez que leva em conta ocorrência da segregação residencial entre grupos raciais a despeito da ascensão sócio-econômica, que é justamente a questão da qual nos ocupamos.

Além disso, podemos pensar este modelo como um complemento das teorizações de Pierre Bourdieu, apresentadas no capítulo 1. Ambos coincidem na premissa segundo a qual as pessoas que ocupam posições semelhantes na estratificação social tendem a residir próximas umas das outras, fazendo com que a segregação residencial se torne uma manifestação das hierarquias e desigualdades da estrutura social. A place-stratification tem a peculiaridade de sublinhar a importância da raça como determinante de localizações residenciais sem desprezar as articulações entre raça 
e classe, haja vista que as desigualdades raciais também caracterizam a estrutura social brasileira. 


\section{Capítulo 3 - Mensuração da Segregação Residencial no Município de São Paulo}

\subsection{Introdução}

Neste capítulo, propomos a aplicação de distintas técnicas de tratamento de dados quantitativos com o objetivo de mensurar a segregação residencial entre negros e brancos no município de São Paulo, revelando seus principais contornos e suas variações de acordo com o estrato social considerado. Retomando a proposta de Edward Telles (1993, 1996), comparamos a distribuição de negros e brancos pertencentes às mesmas faixas de renda. Deste modo, avaliamos a hipótese de que negros e brancos nas faixas de renda mais altas tendem a se concentrar em espaços distintos, havendo, portanto, um grau maior de segregação entre estes grupos nestes estratos.

Para tanto, utilizamos dados da Amostra do Censo de 2000, realizado pelo Instituto Brasileiro de Geografia e Estatística (IBGE). A amostra do Censo é composta por $10 \%$ do total da população recenseada, aos quais é aplicado um questionário mais longo e minucioso, que inclui perguntas sobre cor/raça, migração e ocupação, por exemplo.

No desenvolvimento deste capítulo, exploramos as características da segregação residencial em São Paulo a partir da aplicação de cinco distintas técnicas: a) o índice de dissimilaridade, a mais tradicional e mais aplicada técnica de medição de segregação, apresentando, também, as principais críticas a este tipo de medida; b) os locationalattainment models, ou modelos de realização locacional, procedimento baseado em análise de regressão, de utilização mais recente na produção acadêmica norteamericana; c) a análise tipológica, que compara a distribuição dos grupos sociais em tipos de áreas previamente determinados Pretecéille (2004); d) adaptaremos quociente locacional - medida proveniente da área de economia regional - para a identificação de áreas com maior ou menor concentração dos grupos sociais; e) por fim, lançamos mão do Índice de Moran Local, técnica que realiza a conversão das quantificações em mapas, e fazemos uma análise destes mapas com o objetivo de localizar principais os espaços onde os grupos estão segregados.

Considerando que a segregação residencial diz respeito a diferenciais na distribuição de grupos populacionais no espaço, para a abordagem empírica da segregação faz-se necessário a definição de alguns parâmetros: os recortes grupais e os 
recortes espaciais. Isto é, uma vez que trataremos da distribuição de grupos, precisamos definir quais clivagens serão adotadas na delimitação destes grupos. E, uma vez que trataremos da distribuição destes grupos no espaço, também precisamos explicitar quais serão as unidades espaciais adotadas.

As unidades espaciais utilizadas para a mensuração da segregação residencial neste trabalho são as áreas de ponderação. As áreas de ponderação (AP) são unidades espaciais que começaram a ser empregadas no Censo de 2000 do IBGE. Trata-se da unidade de maior desagregação para qual são divulgados os dados da amostra do censo. As APs são agregados de setores censitários, delimitadas pelo IBGE. O Município de São Paulo tem ao todo 456 áreas de ponderação que, por sua vez, são agrupadas em 96 distritos. Nesta cidade, as áreas de ponderação têm, em média, 6665 domicílios, dos quais $10 \%$ compõem a amostra do censo. A população média das APs de São Paulo é de 22.885 habitantes. A seguir, apresentamos o mapa do município de São Paulo com o traçado de seus distritos e áreas de ponderação (Mapa 1).

Como este trabalho aborda a segregação residencial no município de São Paulo a partir da articulação das perspectivas de classe e de raça, devemos classificar a população de São Paulo segundo grupos raciais e grupos de classe ou estratos sócioeconômicos.

Para operacionalizar classe social, optamos por utilizar as informações da variável "rendimento domiciliar mensal em salários-mínimos" - colhidas na Amostra do Censo de 2000 - que compreende a soma dos rendimentos de todos os moradores de um dado domicílio (com exceção de pensionistas, empregados domésticos e parentes destes últimos). Na data de referência do Censo de 2000, o salário mínimo brasileiro era de 151 reais, que correspondia a aproximadamente um valor entre 80 e 90 dólares. Então, a partir dos valores da renda domiciliar, agrupamos a população em quatro estratos hierarquizados: até 5 salários-mínimos, de 5 a 10 salários-mínimos, de 10 a 20 salários-mínimos, e acima de 20 salários-mínimos. ${ }^{27}$ Considerando estas quatro faixas de renda, os habitantes de São Paulo se distribuem de acordo com a tabela 1: 34,9\% dos.

\footnotetext{
${ }^{27}$ Optamos pela utilização das faixas de renda domiciliar para operacionalizar classe social por este ser um critério que, além de ser significativo enquanto distinção de classe, também nos permite incluir o maior número de indivíduos nas nossas análises, de modo que todos os habitantes do domicílio seriam classificados. Como possível alternativa, testamos a utilização da classificação EGP de status sócioocupacional. Mas se optássemos por esse tipo de variável sócio-econômica, nossa análise se restringiria apenas à população formalmente ocupada. Não obstante, os resultados obtidos a partir desta classificação foram muito semelhantes àqueles obtidos a partir da utilização da renda domiciliar.
} 
Mapa 1: Divisão dos Distritos e Áreas de Ponderação do Município de São Paulo.

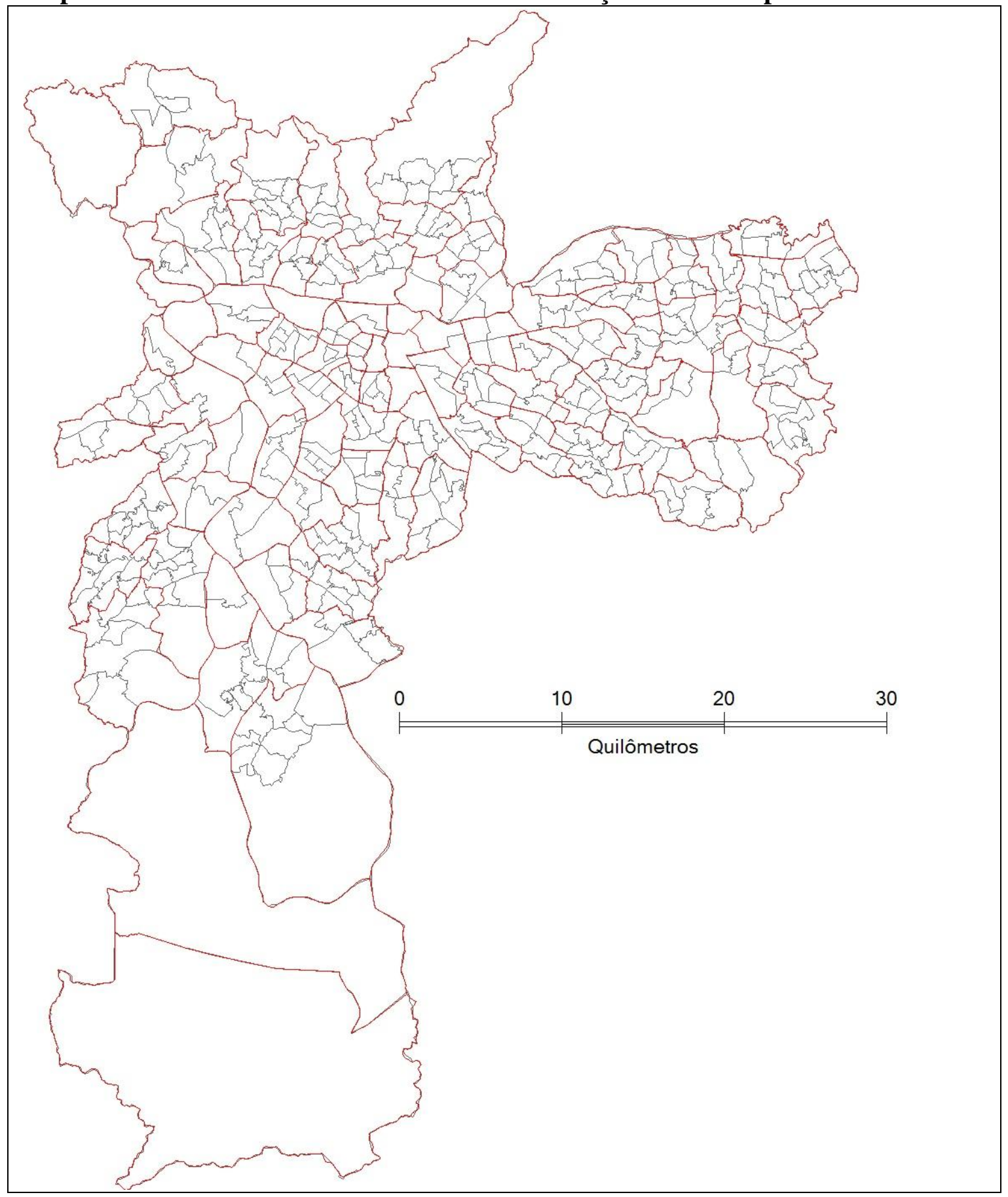

Tabela 1 - Composição da população do Município de São Paulo por faixas de renda (2000)

\begin{tabular}{|l|c|c|}
\hline Faixa de Renda & N & \% \\
\hline Até 5 SM & 3.624 .704 & 34,9 \\
De 5 a 10 SM & 2.806 .554 & 27,0 \\
De 10 a 20 SM & 2.051 .972 & 19,8 \\
Acima de 20 SM & 1.896 .842 & 18,3 \\
Total & $\mathbf{1 0 . 3 8 0 . 0 7 2}$ & $\mathbf{1 0 0 \%}$ \\
\hline
\end{tabular}

Fonte: Amostra do Censo de 2000/IBGE 
paulistanos vivem em domicílios com renda de até 5 salários-mínimos, $27 \%$ em domicílios de 5 a 10 salários-mínimos, 19,8\% de 10 a 20 salários-mínimos; e 18,3\% dos paulistanos moram em domicílios cuja soma dos rendimentos é superior a 20 saláriosmínimos

Os grupos raciais são operacionalizados a partir das respostas à questão sobre raça / cor presente no questionário da amostra do Censo. A distribuição das respostas dos habitantes da cidade de São Paulo (em número de 10.435.546, na data de referência do Censo de 2000) a esta questão pode ser verificada na tabela 2, a seguir.

\begin{tabular}{|l|r|c|}
\hline \multicolumn{3}{|c|}{ Tabela 2- Composição da população do } \\
Município de São Paulo segundo cor ou \\
raça (2000)
\end{tabular}

Considerando que este trabalho enfoca as relações entre negros e brancos, e tendo em vista as pequenas proporções das populações classificadas como amarela $(2 \%)$, indígena $(0,2 \%)$ e ignorado $(0,8 \%)$, excluímos estes grupos da análise, reunindoos na categoria outros. Os grupos pretos e pardos serão reunidos na categoria negros. Assim, para nossas análises, partiremos da constatação de que a população paulistana é composta por $30 \%$ de negros e $67 \%$ de brancos.

Nota-se, na Tabela 3, que os chefes de domicílio classificados como pretos e pardos têm renda média muito próxima. Os pretos e pardos do Município de São Paulo também possuem uma distribuição semelhante nas distintas faixas de renda e nas áreas de ponderação do município.

Conforme a Tabela 4, notamos que os negros têm uma distribuição bem distinta da que apresentam os brancos nas diversas faixas de renda. Quase metade da população negra (49.3\%) está na faixa de até 5 salários-mínimos, reduzindo-se nas faixas seguintes até atingir o índice de apenas 5,5\% na faixa acima de 20 salários-mínimos. Já a população branca se divide praticamente de igual maneira entre as quatro faixas (29\%; 


\begin{tabular}{|c|c|}
\hline \multicolumn{2}{|c|}{$\begin{array}{c}\text { Tabela } 3 \text { - Média das Rendas dos } \\
\text { Responsáveis pelos Domicílios (em } \\
\text { Salários-Mínimos) }\end{array}$} \\
\hline $\begin{array}{l}\text { COR OU } \\
\text { RAÇA }\end{array}$ & $\begin{array}{c}\text { Média de Renda (em } \\
\text { SM) }\end{array}$ \\
\hline Branca & 11,3554 \\
\hline Preta & 4,3151 \\
\hline Amarela & 16,4475 \\
\hline Parda & 4,1160 \\
\hline Indígena & 4,5233 \\
\hline Ignorado & 6,6119 \\
\hline Total & 9,3012 \\
\hline
\end{tabular}

Tabela 4 - Distribuição dos grupos Raciais por Faixas de Renda Domiciliar (em SM) (2000)

\begin{tabular}{|crrrrr|}
\hline $\begin{array}{c}\text { Faixas de Renda } \\
\text { Domiciliar (em SM) }\end{array}$ & Brancos & \multicolumn{2}{c|}{ Negros } & Outros & \multicolumn{1}{c|}{ Total } \\
\hline \multirow{2}{*}{ Até 5 SM } & Contagem & 2.021 .005 & 1.537 .670 & 66.028 & 3.624 .703 \\
& \% & $\mathbf{2 9 , 0 \%}$ & $\mathbf{4 9 , 3 \%}$ & $\mathbf{2 1 , 7 \%}$ & $\mathbf{3 4 , 9 \%}$ \\
\hline \multirow{2}{*}{ De 5 a 10 SM } & Contagem & 1.801 .423 & 946.462 & 58.669 & 2.806 .554 \\
& \% & $\mathbf{2 5 , 9 \%}$ & $\mathbf{3 0 , 4 \%}$ & $\mathbf{1 9 , 3 \%}$ & $\mathbf{2 7 , 0 \%}$ \\
\hline \multirow{2}{*}{ De 10 a 20 SM } & Contagem & 1.522 .915 & 462.086 & 66.971 & 2.051 .972 \\
& \% & $\mathbf{2 1 , 9 \%}$ & $\mathbf{1 4 , 8 \%}$ & $\mathbf{2 2 , 0 \%}$ & $\mathbf{1 9 , 8 \%}$ \\
\hline \multirow{2}{*}{ Acima de 20 SM } & Contagem & 1.612 .786 & 171.108 & 112.949 & 1.896 .843 \\
& \% & $\mathbf{2 3 , 2 \%}$ & $\mathbf{5 , 5 \%}$ & $\mathbf{3 7 , 1 \%}$ & $\mathbf{1 8 , 3 \%}$ \\
\hline \multirow{2}{*}{ Total } & Contagem & 6.958 .129 & 3.117 .326 & 304.617 & 10.380 .072 \\
& \% & $\mathbf{1 0 0 , 0 \%}$ & $\mathbf{1 0 0 , 0 \%}$ & $\mathbf{1 0 0 , 0 \%}$ & $\mathbf{1 0 0 , 0 \%}$ \\
\hline OOutros: corresponde a soma de: amarelos, indigenas e ignorados. & & & & \\
\hline
\end{tabular}

Fonte: Amostra do Censo de 2000 / IBGE

\begin{tabular}{|c|c|c|c|c|c|}
\hline \multicolumn{5}{|c|}{ Faixas de Renda Domiciliar (em SM) } & \multirow{2}{*}{ Total } \\
\hline & Até 5 SM & De 5 a $10 S$ & 10 a $20 S$ & Acima de $20 \mathrm{SM}$ & \\
\hline Brancos & $55,8 \%$ & $64,2 \%$ & $74,2 \%$ & $85,0 \%$ & $67,0 \%$ \\
\hline Negros & $42,4 \%$ & $33,7 \%$ & $22,5 \%$ & $9,0 \%$ & $30,0 \%$ \\
\hline Outros $^{1}$ & $1,8 \%$ & $2,1 \%$ & $3,3 \%$ & $6,0 \%$ & $3,0 \%$ \\
\hline Total & $100,0 \%$ & $100,0 \%$ & $100,0 \%$ & $100,0 \%$ & $100,0 \%$ \\
\hline
\end{tabular}


$25,9 \% ; 21,9 \% ; 23,2 \%)$, com um ligeiro aumento na primeira delas. Nas faixas acima de 10 salários-mínimos, estão $45,1 \%$ do total de brancos e $20,3 \%$ do total de negros. A Tabela 5 mostra que a proporção de brancos cresce progressivamente conforme subimos nas faixas de renda, enquanto a proporção de negros diminui.

\subsection{Análise do índice de dissimilaridade}

O índice de dissimilaridade consolidou-se na sociologia estadunidense como a principal medida de segregação residencial a partir da publicação do artigo de Duncan e Duncan (1955). Nele, os autores demonstraram que este índice era a medida mais sintética das disponíveis, abarcando as informações contidas nas outras medidas utilizadas naquela época.

O índice de dissimilaridade (D) capta o grau em que dois grupos sociais não estão uniformemente [evenly] distribuídos no espaço de uma cidade. Ou seja, a dissimilaridade seria o contrário da uniformidade, em se tratando da distribuição dos grupos no espaço. Massey e Denton (1988) definem da seguinte maneira a noção de uniformidade:

\footnotetext{
"Uniformidade [Evenness] se refere à distribuição diferencial de dois grupos sociais entre as unidades espaciais de uma cidade. Uma minoria é dita segregada se nãouniformemente [unevenly] distribuída sobre as unidades espaciais. A uniformidade [Evennes] não é medida em termos absolutos, mas é balanceada relativamente a algum outro grupo. A uniformidade [Evenness] é maximizada e a segregação é minimizada quando todas as unidades espaciais têm o mesmo número relativo de membros das minorias ou das maiorias que a cidade como um todo. Ao contrário, a uniformidade [evenness] é minimizada, e a segregação é maximizada, quando nenhum membro de minoria e maioria compartilhar uma mesma área de residência." (Massey e Denton 1988: 283-4, tradução nossa).
}

Assim, a uniformidade se define a partir da proporção de cada grupo na composição da população total da cidade, e do quanto que a distribuição destes grupos pelas diversas áreas da cidade replica esta composição. Ou seja, considerando que a população de São Paulo é composta por $30 \%$ de negros, um padrão residencial uniforme requer que cada bairro ou unidade espacial desta cidade também tenha $30 \%$ de negros. Quanto mais a composição da população dos bairros se afastar destes $30 \%$ de negros - 
havendo, por exemplo, alguns bairros com muito mais do que $30 \%$ de negros e outros bairros com menos -, menor será a uniformidade de distribuição desta população e, por conseguinte, maior será o valor do índice que aponta o grau de segregação. Em suma, o índice evidencia a relação entre a composição da população de cada unidade espacial e a composição da população de toda a cidade.

A cálculo do índice de dissimilaridade (D) foi feito segundo a fórmula a seguir:

$$
D=\frac{1}{2} \sum\left|\frac{x_{i}}{X}-\frac{y_{i}}{Y}\right|
$$

Onde $x i$ e $y i$ representam o número de membros dos grupos $\mathrm{X}$ e $\mathrm{Y}$ na unidade espacial i; e X e Y representam o total da população destes grupos em toda a cidade.

$\mathrm{O}$ índice $\mathrm{D}$ varia de 0 a 1 , onde 1 significa segregação total e 0 significa uniformidade total na distribuição dos grupos. Para facilitar sua comunicação e compreensão, muitos autores representam o resultado do índice de dissimilaridade com valores entre 0 e 100 (ou seja, multiplicam os valores originais por 100). Com base nos resultados obtidos nas pesquisas sobre as cidades norte-americanas, convencionou-se considerar os valores de D abaixo de 30 (ou 0,3 ) como baixos, aqueles entre $30(0,3)$ e $60(0,6)$ como moderados, e os acima de $60(0,6)$ como altos.

O resultado do índice costuma ser interpretado como indicando a proporção da população de um determinado grupo da cidade que teria que trocar de área com outro para que se obtenha um padrão residencial uniforme do ponto de vista da proporção de cada grupo na composição da população da cidade. Assim, caso o índice de dissimilaridade resulte em 0,80 , considera-se que $80 \%$ da população de um grupo deveria trocar de área para que se obtenha uma distribuição uniforme dos grupos considerados no cálculo do índice. (Cf. Massey e Denton 1988; Cortese, Falk e Cohen 1976)

Calculamos o índice de dissimilaridade entre negros e brancos no município de São Paulo. Os resultados são apresentados na Tabela 6 a seguir.

A Tabela 6 apresenta o cálculo de índice de dissimilaridade entre negros e brancos para todo o município e para as faixas de renda até 5 salários-mínimos, de 5 a 10 salários-minímos, de 10 a 20 salários-mínimos, e acima de 20 salários-mínimos. O resultado do índice de dissimilaridade entre todos os negros e brancos do município é 


\begin{tabular}{|l|c|}
\hline \multicolumn{2}{|c|}{ Tabela 6 - Índice de Dissimilaridade entre os Negros e Brancos... } \\
\hline ...do Município de São Paulo & 0,3010 \\
\hline ... da Faixa de Renda até 5 Salários Mínimos & 0,1849 \\
\hline ... da Faixa de Renda entre 5 e 10 Salários Mínimos & 0,2261 \\
\hline ... da Faixa de Renda entre 10 e 20 Salários Mínimos & 0,2816 \\
\hline ... da Faixa de Renda acima de 20 Salários Mínimos & 0,3631 \\
\hline
\end{tabular}

moderado: $0,3010{ }^{28}$ Nos chama mais atenção o fato do índice ser baixíssimo para a faixa de renda mais baixa e do índice ser acima da média na faixa mais alta, o que nos indica que a segregação por raça se torna mais pronunciada conforme consideramos os estratos sociais mais altos. Ou seja, se nas classes mais baixas os negros e brancos estão espacialmente muito próximos uns dos outros, nas classes mais altas eles se tornam mais distantes.

Estes valores estão abaixo dos índices de dissimilaridade apresentados por Charles (2003), referentes as 50 maiores áreas metropolitanas norte-americanas, a partir de informações do Censo realizado no ano 2000 nos EUA. Lá, o menor valor de D é de 0,37, obtido em Orange County e em Salt Lake City / Ogden. A metrópole norteamericana com maior segregação entre negros e brancos é Detroit, com um valor de D de 0,85. O valor médio de D para as 50 maiores metrópoles dos EUA é de 0,62. Entretanto, é importante ter cuidado ao comparar índices de dissimilaridade referentes a distintos contextos sociais e operacionais. Estes valores foram calculados adotando-se census tracts como unidade espacial, que corresponderiam aos nossos setores censitários, unidades muito menores que as áreas de ponderação. E, como veremos a seguir, a utilização de unidades espaciais menores pode levar a um inflacionamento do índice resultante.

Para os índices exibidos na tabela seguinte (Tabela 7), adotamos como grupo de referência a população com renda domiciliar acima de 20 salários-mínimos, e calculamos o índice de dissimilaridade deste grupo com relação à população total das três primeiras faixas de renda, e também com relação aos negros e brancos de cada uma destas três primeiras faixas. O objetivo é averiguar o quão distante cada grupo (negros e brancos em distintas faixas de renda) está do estrato social mais alto da cidade.

${ }^{28}$ É importante lembrar que esta qualificação de "moderado" tem como referência os padrões de segregação racial dos Estados Unidos.

Além disso, também é interessante notar que o índice de dissimilaridade calculado por Carvalho e Barreto (2007) para Salvador (0,30155) resultou muito próximo de índice que calculamos para São Paulo. 


\begin{tabular}{|l|l|l|l|}
\hline \multicolumn{4}{|c|}{$\begin{array}{c}\text { Tabela } 7 \text { - Dissimilaridade de cada grupo para com a faixa de renda } \\
\text { domiciliar acima de } 20 \text { salários-mínimos }\end{array}$} \\
\hline & Todos & Brancos & Negros \\
\hline Até 5 salários-mínimos & 0,5833 & 0,5364 & 0,6560 \\
\hline 5 a 10 salários-mínimos & 0,4880 & 0,4440 & 0,5924 \\
\hline 10 a 20 salários-mínimos & 0,3567 & 0,3160 & 0,5233 \\
\hline
\end{tabular}

Primeiramente, considerando apenas o índice de dissimilaridade por faixas de renda (sem observar a raça), notamos que existe uma significativa segregação sócioeconômica em São Paulo. O índice D entre a faixa de renda acima de 20 saláriosmínimos e a faixa logo abaixo, de 10 a 20 salários-mínimos, é de 0,3567; subindo para 0,488 entre a faixa mais alta e a faixa de 5 a 10 salários-mínimos; e atingindo o valor de 0,5833 entre a faixa mais baixa (até 5 salários-mínimos) e a faixa mais alta.

Agora, distinguindo-se o valor do índice D de negros e brancos em cada uma das três primeiras faixas de renda para com a faixa de renda mais alta, notamos que, se é expressiva a segregação entre os estratos sócio-econômicos, ela é ainda mais forte se considerarmos os grupos raciais separadamente.

O índice de dissimilaridade dos negros para com o grupo mais abastado é sempre maior que o dos brancos em qualquer uma das faixas de renda. Ou seja, os negros sempre estão mais distantes do grupo mais rico do que os brancos com as mesmas condições de renda. É importantíssimo atentar para o fato de que os negros com renda domiciliar entre 10 e 20 salários-mínimos tenham um grau de dissimilaridade para com o grupo mais rico de 0,5233 , muito próximo do valor calculado para os brancos na faixa de renda de até 5 salários-mínimos (0,5364). Portanto, de acordo com o resultado dos índices, um branco da faixa de renda mais baixa está quase tão próximo das pessoas da camada social mais alta da cidade quanto está um negro que pertença a segunda faixa de renda mais alta.

\section{Crítica ao Índice de Dissimilaridade}

O índice de dissimilaridade prevaleceu como a medida padrão de segregação sem contestação por mais de 20 anos, entre 1955 e 1976. A este período Massey e Denton (1988) apelidaram de Pax Duncana, em referência ao artigo de Duncan e Duncan de 1955, que consolidou o índice. 
Em 1976, Cortese, Falk e Cohen publicam a primeira grande crítica ao índice de dissimilaridade. O primeiro argumento destes autores atacava a própria noção de dissimilaridade, enquanto oposta de uniformidade. Segundo eles, a perfeita uniformidade seria um ideal não verificado empiricamente. Deste modo, o oposto da dissimilaridade deveria ser uma distribuição aleatória (e não necessariamente uniforme) dos grupos pelas áreas da cidade. Assim, em uma distribuição aleatória dos grupos sobre as áreas, flutuações acima ou abaixo do padrão considerado uniforme não deveriam ser entendidas como tendências à dissimilaridade.

Esta crítica de Cortese et al (1976), ensejou a reabertura das reflexões e estudos sobre medidas de segregação, multiplicando, a partir de então, as propostas de novas técnicas de mensuração da segregação residencial.

Entretanto, o amplo uso do índice de dissimilaridade por décadas na literatura de segregação e o fato dos testes estatísticos terem apontado um alto grau de correlação entre D e outras medidas de uniformidade (eveness) mantiveram o seu prestígio, de modo que a maior parte dos autores continuou a optar pelo índice de dissimilaridade como medida para a dimensão uniformidade da segregação. (Cf. Massey e Denton 1988).

A segunda crítica de Cortese, Falk e Cohen (1976) mostram que, o índice de dissimilaridade tende a inflacionar quando o número de membros das minorias é muito pequeno comparado à quantidade de unidades espaciais utilizadas para seu cálculo. ${ }^{29}$ Assim, precisamos estar atentos às variações na proporção dos grupos minoritários em cada cidade quando formos realizar comparações. Inversamente, quanto maior a proporção da minoria, menor deve ser o valor do índice, mas não necessariamente será menor a segregação.

Além dos julgamentos apontados acima, outras críticas comuns na literatura sobre segregação foram reunidas no texto de Sabatini e Sierralta (2006).

A primeira delas é uma característica inerente a todo tipo de índice: representa, através de um só número, a segregação da cidade inteira. Ou seja, o valor no qual resulta o índice para uma cidade pode esconder as variações da segregação internas à cidade.

Vejamos os exemplos mostrados na figura 1. A figura traz duas comparações entre cidades hipotéticas que apresentam igual valor do índice. Mas, na realidade, as

\footnotetext{
${ }^{29}$ Esta possibilidade já havia sido sinalizada por Duncan e Duncan (1955).
} 
duas "cidades" da coluna à direita apresentam maior segregação, pois internamente às unidades espaciais há aglomeração dos grupos. Assim, as pessoas de um grupo minoritário poderiam estar dispersas ou aglomeradas no interior de uma área, e o índice seria o mesmo. Ou seja, o índice não capta possíveis aglomerações no interior das unidades espaciais adotadas.

Figura 1: O problema da Validade da índice de Dissimilaridade (Sabatini e Sierralta 2006: 192)

O problema da validade do índice de dissimilaridade

Cidades com índice de dissimilaridade zero

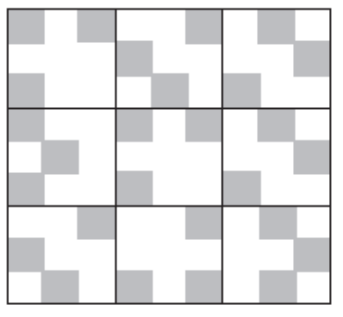

Em ambas as cidades, o índice de dissimilaridade é zero; existe um terço da população "cinza" em toda a cidade e em cada uma de suas área internas.

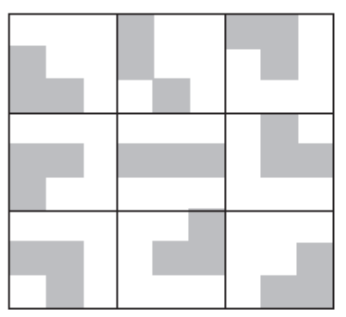

Porém, na segunda cidade, a população "cinza" está mais segregada espacialmente do que na primeira, porque se aglomera mais no interior de cada zona.

Cidades com índice de dissimilaridade positivo e igual

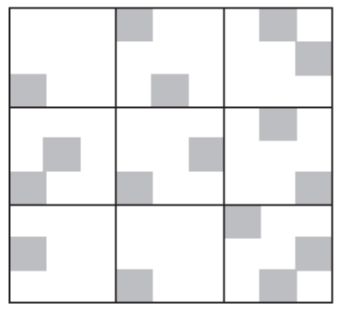

Em ambas as cidades, o índice de dissimilaridade maior do que zero e igual: existem 3 zonas com 1 bloco cinza, 3 zonas com 2 blocos cinzas e 3 zonas com 3 blocos cinzas.

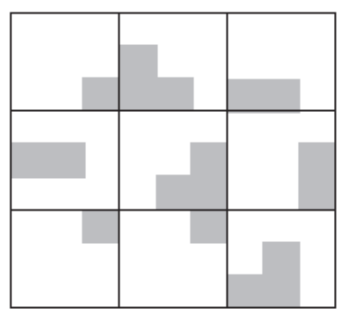

Porém, na segunda cidade, a população "cinza" está mais segregada espacialmente do que na primeira, porque se aglomera mais no interior de cada zona. 

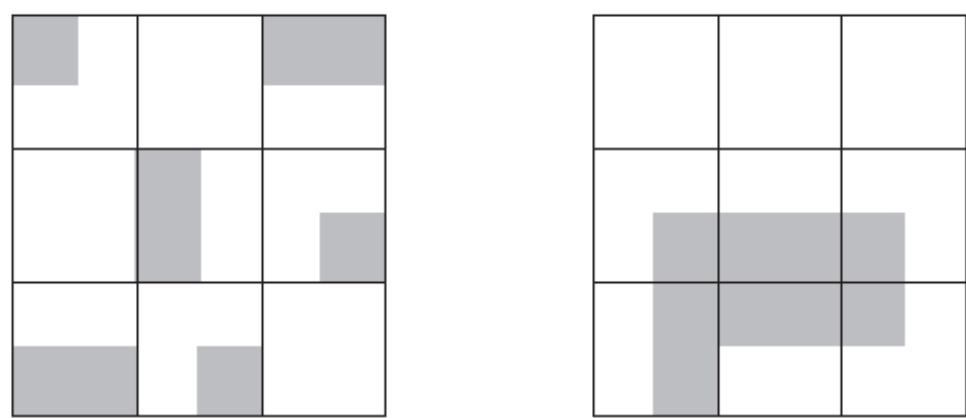

Ambas as cidades têm o mesmo índice de dissimilaridade: 3 zonas sem população "cinza"; 3 zonas com 1 bloco cinza e 3 zonas com dois blocos cinzas. Sem dúvida, na segunda cidade um agrupamento diferente dessas zonas gera um padrão mais segregado do que na primeira.

Consideremos agora as duas cidades hipotéticas da figura 2. Ambas possuem o mesmo valor do índice de dissimilaridade, mas a disposição dos grupos na segunda "cidade" revela um padrão mais segregado do que na primeira, pois existe uma aglomeração em uma grande região, cujos limites não coincidem com as unidades espaciais utilizadas como referência para o cálculo de índice, e que é maior que estas unidades. Ou seja, o índice não capta a segregação que ocorre em uma escala maior do que a definida pelas áreas utilizadas como referência e nem a segregação que ocorre em uma área que não obedece as delimitações das unidades espaciais adotadas. 


\section{o problema da grade}

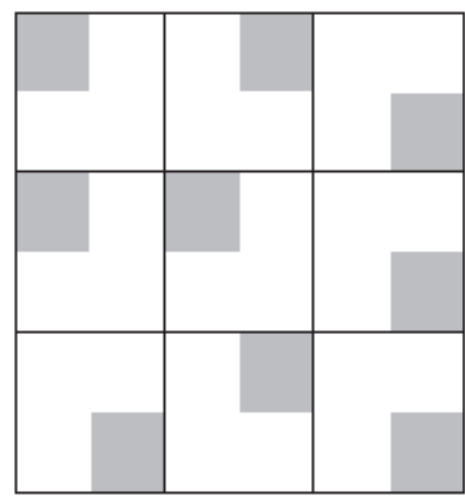

Ambas as cidades têm cerca de $25 \%$ da população "cinza" com a mesma distribuição espacial. Ao divididr-se em 9 zonas, a primeira cidade apresenta um índice de dissimilaridade igual a zero, Cada zona tem cerca de $25 \%$ de população "cinza".

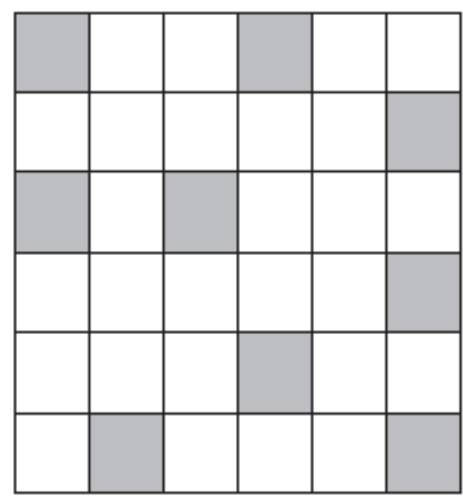

Em contraposição, a segunda cidade foi dividida em 36 zonas, apresentando alto índice de dissimilaridade. Os $75 \%$ da população "cinza", ocupando o total das zonas em que vivem, deveriam mudar de residência.

A figura 3 revela outro problema que afeta o índice de dissimilaridade: a alteração do desenho, quantidade e/ou do tamanho das unidades espaciais de referência altera o resultado do índice - este é o chamado grid problem ou "problema da grade". Quanto menor for a escala (ou seja, quanto menores e mais numerosas as unidades espaciais), o valor do índice tenderá a ser maior. "Quanto maior a área, mais se parece com a cidade, e o índice deverá tender a zero (a distribuição de grupos para cada área vai se assemelhando à da cidade). Trata-se de uma questão da escala de análise." (Sabatini e Sierralta 2006: 176)

“O problema é que a necessária delimitação das áreas da medição restringe a informação a uma única escala espacial. Abaixo ou acima dela, a segregação não está sendo medida. Este é um problema metodológico geral dos estudos de segregação: para medi-lo, devemos definir uma área de compilação da informação, ou usar uma existente (...), operação que interfere diretamente no fenômeno que estamos estudando e tentando medir. (...) De fato, trata-se de um problema metodológico geral para todos os instrumentos que buscam medir relações sociais estudando áreas ou parcelas de território: ao definir uma área, estamos influenciando os resultados que obteremos." (Sabatini e Sierralta 2006: 175-9) 
Assim, os autores mostram que uma operação fundamental para todos as técnicas de mensuração da segregação residencial - qual seja, a delimitação de unidades espaciais - pode levar a distorções nos resultados das medidas. Frente a estes problemas, eles recomendam que, primeiramente, sejam sempre levadas em consideração estas ressalvas na aplicação e interpretação das medidas de segregação, visto que elas revelam as suas limitações. E, em segundo lugar, que busquemos repetir as medições em várias escalas diferentes e tendo como base diferentes traçados das unidades espaciais.

Entretanto, diante da impossibilidade de realizarmos as medições em níveis menores que o das áreas de ponderação (uma vez que não dispomos de informações sobre raça desagregadas no nível dos setores censitários), propomos, então, diversificar as técnicas de abordagem da segregação. Esta "solução" não elimina o problema da adoção de unidades espaciais não modificáveis, mas permite-nos que, através da comparação dos resultados das diferentes formas de medida, possamos criticar ou reforçar as conclusões que podem nos suscitar uma ou outra técnica isolada.

\subsection{Locational-Attainment Models}

A partir da década de 1990, os pesquisadores Richard Alba e John Logan passaram a aplicar um novo método de estudo da segregação, com um enfoque individual em vez de grupal, que permitiria a análise dos determinantes da localização dos indivíduos a partir de suas características específicas (Alba e Logan 1992; Alba e Logan 1993).

Tais métodos são os chamados locational-attainment models (ou modelos de realização locacional), que permitem revelar como membros de diferentes grupos podem converter certas características individuais - como renda, escolaridade, etc. - em uma localização residencial em bairros de alta renda ou em proximidade residencial com grupos majoritários. Tais modelos baseiam-se na técnica estatística da análise de regressão OLS, e assemelham-se aos modelos de realização de status familiar (familiar status-attainment models) utilizados na literatura de estratificação e de mobilidade social.

De acordo com os autores citados, a utilização desta nova técnica representa grandes avanços com relação às limitações decorrentes da aplicação dos índices de 
segregação. Os índices, como as medidas agregadas de modo geral, resultam em valores únicos que representam grupos delimitados para o seu cálculo, ofuscando variações individuais entre membros destes grupos.

Assim, o resultado de um índice de segregação entre negros e brancos, por exemplo, mascararia características específicas dos membros destes grupos, como a renda, que podem ser muito importantes nos processos que levam à segregação. Para contornar este problema, calcula-se o índice de dissimilaridade controlando-se por determinadas faixas de renda, como fizemos anteriormente. Entretanto, como havia sido apontado por Cortese, Falks e Cohen (1976), o valor de D tende a inflacionar no caso do tamanho relativo da minoria em análise ser muito pequeno, superestimando a segregação. E, normalmente, a proporção do grupo minoritário tende a decrescer na medida em que consideramos categorias sócio-econômicas mais altas. (Logan, Alba e Leung 1996; Alba, Logan e Stults 2000).

Postas estas ressalvas, os autores apresentam sua opção pelo modelo de realização locacional (locational-attainment model). Os modelos descrevem em que medida determinadas características dos indivíduos ou de seus domicílios estão relacionadas com as características das áreas em que estes indivíduos residem (Alba e Logan 1993). Nos modelos, as variáveis dependentes são características dos bairros nos quais os indivíduos residem. Estas podem ser a renda média deste bairro, a percentagem de brancos na população da área, a taxa de criminalidade etc. As variáveis independentes são variáveis de nível individual ou domiciliar, como, por exemplo, renda, escolaridade, raça, se o domicílio é próprio ou alugado, etc. Assim, podemos mensurar o quanto os atributos individuais escolhidos são bons preditores das características das localidades onde as pessoas residem. Essa forma de abordagem permite a adição de diversos controles, para além das faixas de renda utilizadas no cálculo dos índices.

Formalmente, tratam-se de modelos de regressão OLS que seguem fórmulas tais como a seguinte:

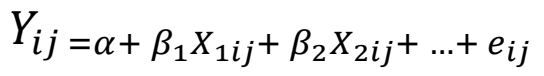


Nesta função, Y é a variável dependente, correspondente a características do bairro j, onde mora o indivíduo i ${ }^{30}$ As variáveis independentes $(\mathrm{X})$ são variáveis de nível individual ou domiciliar como realização educacional ou renda. ${ }^{31}$ Os Betas $(\beta)$ são os coeficientes das variáveis independentes. "Os coeficientes $\left[\beta_{1}, \beta_{2}\right.$, etc] em equações deste tipo podem ser interpretados em termos da capacidade dos membros de um dado grupo converter algumas características pessoas ou domiciliares $\left[X_{1}, X_{2}\right.$, etc $]$ em uma localização residencial favorável [expressa na variável dependente Y]." (Alba, Logan e Stults 2000: 547, tradução nossa).

Replicaremos, aqui, em caráter experimental, ${ }^{32}$ um dos exemplos de locationalattainment model apresentados no artigo "How Segregated are Middle-Class AfricanAmericans", de Alba, Logan e Stults (2000), todavia utilizando os dados do município de São Paulo. ${ }^{33}$

No exemplo escolhido, Alba, Logan e Stults (2000) elegem como variável dependente a mediana das rendas domiciliares dos setores censitários (census tracts). ${ }^{34}$ As variáveis independentes são a condição de propriedade do imóvel (se próprio ou alugado), a localização da residência (se em subúrbios ou em central cities) e mais duas variáveis sócio-econômicas: renda domiciliar e escolaridade.

O modelo é estimado separadamente para negros e brancos. A observação dos coeficientes $\beta$ dos modelos de cada grupo permite-nos comparar o quanto cada um destes grupos consegue converter os atributos individuais ou domiciliares em uma residência numa vizinhança de renda mais alta. Se observarmos grandes diferenças nos parâmetros de negros e brancos, temos uma evidência de que a raça importa para uma moradia num bairro mais rico. Consequentemente, o resultado dos valores preditos da variável dependente serão diferentes para negros e brancos com características semelhantes (Alba e Logan 1993).

Para a aplicação do modelo aos dados de São Paulo, realizamos algumas modificações. A variável dependente será o logaritmo da mediana das rendas

\footnotetext{
${ }^{30} \mathrm{O}$ valor da variável dependente (Y) é o igual para todos os indivíduos (i) residentes num mesmo bairro (j).

${ }^{31} \mathrm{O}$ coeficiente $\alpha$ é a constante de interceptação da reta com o eixo y (também chamada de intercepto). $\varepsilon$ representa os erros do modelo.

32 É importante ressaltar que não temos conhecimento de aplicações anteriores desta técnica em estudos sobre segregação no Brasil.

${ }^{33}$ Registro meus sinceros agradecimentos a Rogério Jerônimo Barbosa, que deu contribuições muito importantes para o trabalho de ajuste destes modelos.

${ }^{34}$ Optou-se pelas medianas, em vêz de médias, porque os resultados das médias são muito afetados por valores extremos.
} 
domiciliares das áreas de ponderação. ${ }^{35}$ A justificativa da variável "local de moradia: central city ou subúrbio" não se aplica ao caso brasileiro. Então a substituímos por uma indicadora de residência em setores censitários subnormais, que representa uma boa aproximação para localização de favelas. Com relação às variáveis sócio-econômicas, mantivemos a escolaridade, mas optamos por não utilizar a renda domiciliar dos indivíduos, pois esta compõe o variável-resposta (dependente). Em seu lugar, empregamos categorias ocupacionais EGP (reagrupadas em seis categorias ordenadas segundo a proximidade de suas rendas médias). Apresentamos o modelo na Tabela 8.

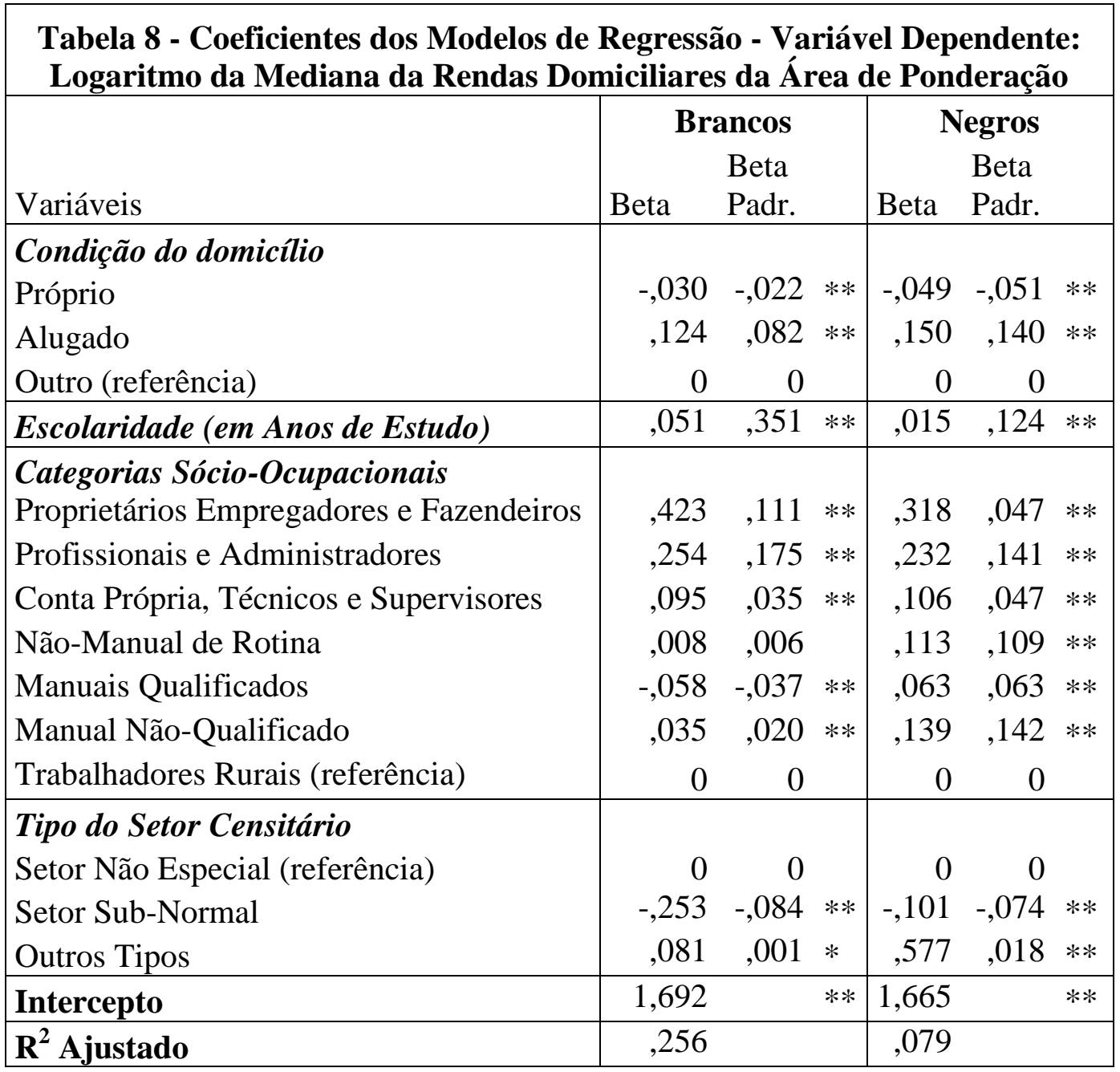

* Significativo a $95 \%$ de confiança / ** Significativo a $99 \%$ de confiança

\footnotetext{
${ }^{35}$ A conversão em logaritmo da mediana das rendas domiciliares melhora a capacidade preditiva $\left(\mathrm{R}^{2}\right)$ do modelo e contribui para que os resíduos se aproximem mais de uma distribuição normal. Uma possível explicação para isto é o fato de que a distribuição de renda no Brasil tem um perfil log-normal. (Cf. Santos 2005: 33-4). Uma das desvantagens de se recorrer à transformação logaritma da variável dependente é a necessidade de realizar a conversão do logaritmo para obtermos o valor predito.
} 
A partir dos valores dos coeficientes $\beta$ para cada modelo, compararemos os efeitos para negros e brancos em termos de "ganhos de localização", ou seja, em que medida cada variável pode proporcionar morar em uma vizinhança de maior renda para os indivíduos de cada grupo.

A melhora de status sócio-econômico leva a melhoras de localização para os dois grupos, mas com algumas diferenças. $\mathrm{O}$ acúmulo de anos de escolaridade, por exemplo, proporciona ganhos de localização maiores para os brancos do que para os negros. Além disso, exercer ocupações com renda média mais elevada (como Profissionais e Administradores, Proprietários Empregadores e Fazendeiros) também rende maiores ganhos para os brancos. Assim, o modelo aponta que os negros residem em vizinhança mais pobres do que as dos brancos independentemente dos ganhos sócioeconômicos de ambos.

Ter um imóvel próprio gera pequenas perdas para ambos os grupos raciais, porém as perdas são um pouco maiores para os negros. Por outro lado, morar em um imóvel alugado gera ganhos residenciais, um pouco maiores para os negros. Viver em um setor subnormal proporciona perdas para os dois grupos, porém maiores para os brancos.

Comparemos casos hipotéticos: De acordo com os resultados do modelo, uma pessoa branca, com dez anos de escolaridade, exercendo uma ocupação da categoria de profissionais e administradores, e morando em casa própria, deverá residir em uma área de ponderação cuja mediana das rendas domiciliares é de 11,3 salários mínimos. Já a mediana das rendas domiciliares de uma pessoa negra com estas mesmas características será de 7,3 salários-mínimos.

Assim, a análise dos modelos mostrou que, de modo geral, as melhorias em atributos individuais ou domiciliares trazem maiores ganhos de localização para os brancos do que para os negros. Ou seja, melhores atributos individuais contam mais para brancos do que para negros no que tange a residir em bairros mais ricos.

Entretanto, a análise dos resíduos aponta para a invalidação destes modelos. Os gráficos 1 a 6 revelam que os modelos ferem alguns pressupostos estatísticos da análise de regressão.

Os primeiros quatro gráficos a seguir testam o "pressuposto da normalidade dos resíduos", ou seja, os resíduos da análise de regressão devem ter uma distribuição normal. Para tanto, nos gráficos 1 e 2, os histogramas deveriam se aproximar da 
distribuição traçada pela linha de normalidade plotada sobre o gráfico; e nos gráficos 3 e 4, os casos (agrupados na linha mais grossa) deveriam estar localizados sobre a linha diagonal. Como estas condições não foram observadas, conclui-se que os modelos não seguem a suposição de normalidade dos resíduos. Entretanto, convém ressaltar que, ao testar outras configurações destes modelos, adicionando mais variáveis independentes, obtivemos melhores resultados nas análises de resíduos.

Os gráficos 5 e 6 testam o pressuposto da homocedasticidade, ou variância constante dos resíduos dos modelos. Para o caso de se verificar a satisfação desta condição, o gráfico de dispersão deve resultar em uma nuvem aleatória de pontos. Fato que não ocorre. Nos dois gráficos notamos uma tendência descendente da nuvem de pontos. Em todas as modificações que testamos para os modelos, verificamos esta mesma tendência descendente nos resíduos.

Uma vez que Richard Alba e John Logan não nos dão informações a respeito da análise de resíduos dos modelos apresentados nos artigos que publicaram, não temos como inferir se os problemas que verificamos são intrínsecos aos locational-attainment models ou se são decorrentes de particularidades do padrão brasileiro de segregação.

Uma hipótese que pode explicar a tendência que observamos nos gráficos 5 e 6 é a de que, por se tratarem de modelos que lidam indivíduos geograficamente associados, é possível que esta associação crie correlações entre os resíduos, resultando nas tendências descendentes que observamos em todos as modificações do modelo que testamos.

Possíveis formas de neutralizar estes problemas são: a inclusão no modelo de variáveis geográficas que não tenham relação com as variáveis sócio-econômicas já presentes nele; ou a aplicação de modelos de regressão linear hierárquica (HLM), que incorporam estruturas de dependência que podem existir entre os dados considerados pelo modelo. 
Análise de Resíduos

Modelo Estimado para os Brancos

Modelo Estimado para os Negros

Gráfico 1

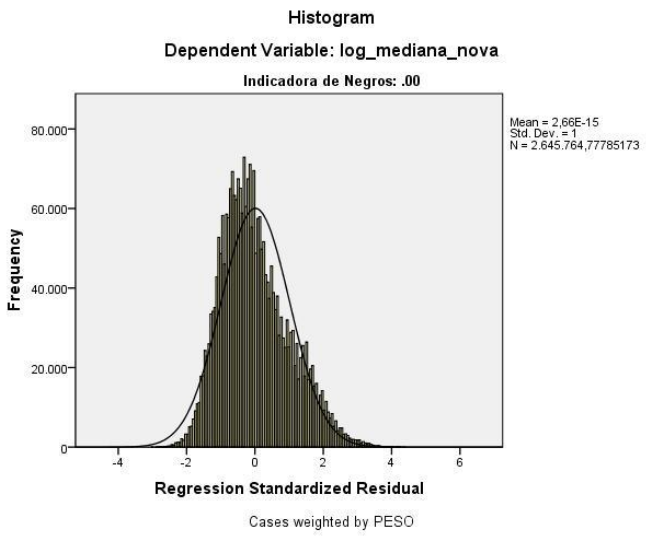

Gráfico 3

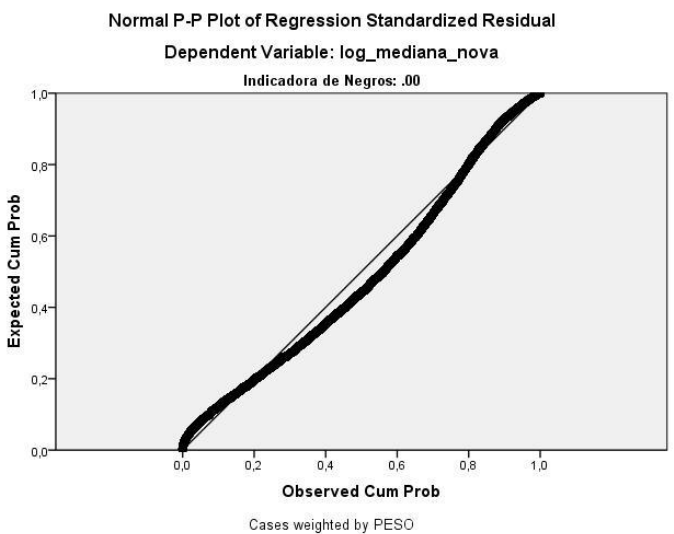

Gráfico 5

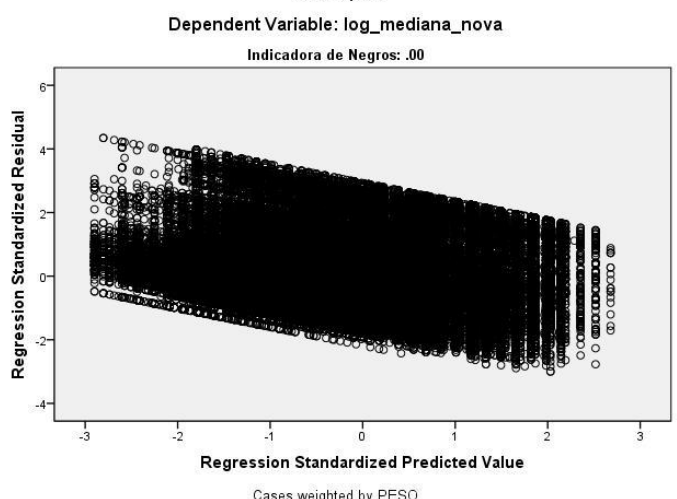

Gráfico 2

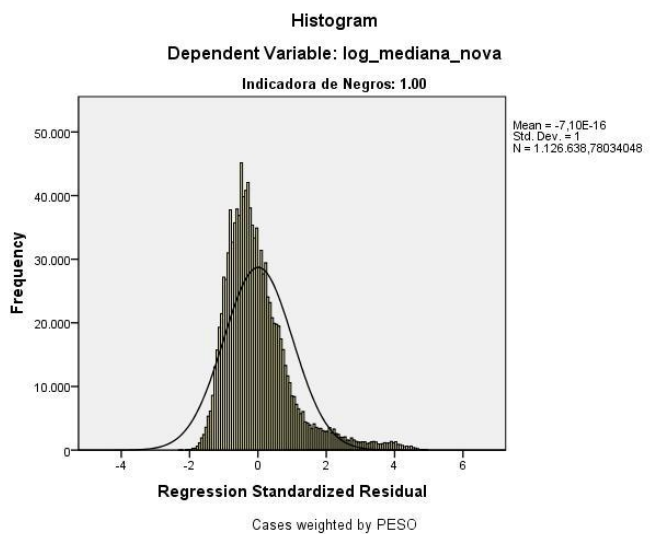

Gráfico 4

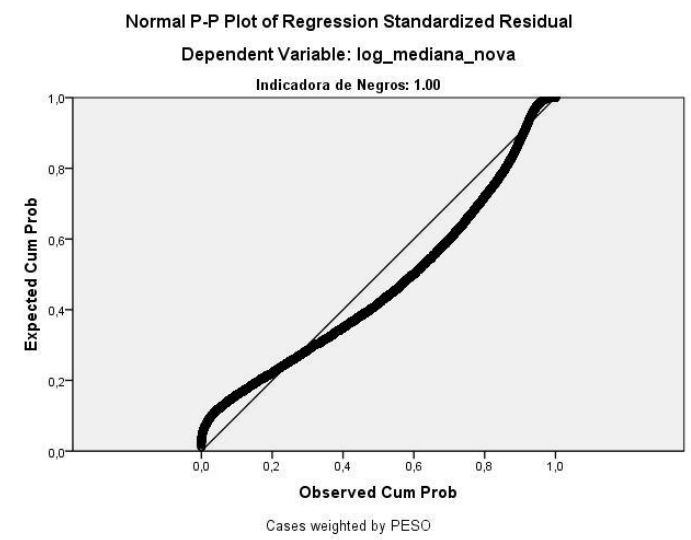

Gráfico 6

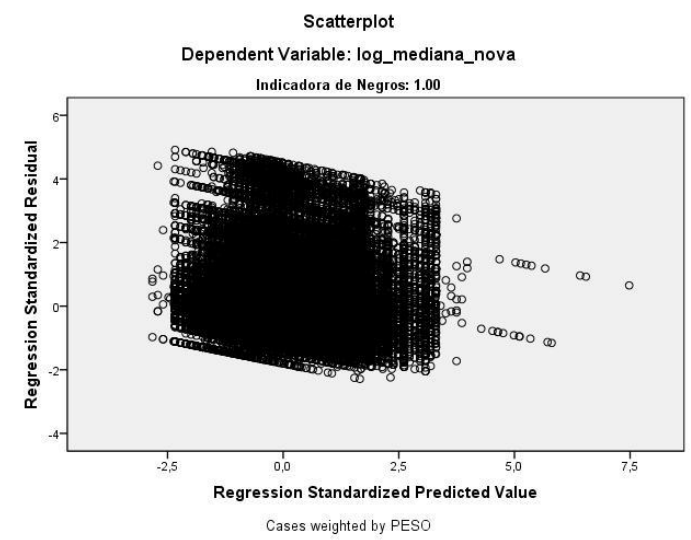




\subsection{Análise tipológica}

Preteceille (2004) define como "análise tipológica" uma forma de identificação da segregação residencial que opera a partir do agrupamento das unidades espaciais em "tipos, classes ou clusters definidos por similitudes de perfis de distribuição das categorias sociais" (p. 16).

A definição de tipos de áreas nos permite qualificar os espaços onde os grupos estão segregados, revelando especificidades das localizações onde se concentram determinados grupos sociais. Isto é uma grande vantagem se considerarmos que os índices nos informam o quanto os grupos estão segregados, mas não nos dizem nada a respeito dos espaços onde eles têm maior ou menor concentração. Porém, a análise tipológica padece de desvantagens comuns às outras formas de medida de segregação, pois os resultados são sensíveis à definição dos grupos sociais e das unidades espaciais.

Para realizar a análise, necessitamos, não apenas de uma classificação dos grupos - já realizada -, mas também tipificar ou classificar as áreas.

Primeiramente, nos reportaremos à classificação das áreas de ponderação da Região Metropolitana de São Paulo utilizada em pesquisas realizadas no âmbito do Centro de Estudos da Metrópole (CEM) (Cf., por exemplo, os estudos reunidos em Marques e Torres 2005), e que serve de parâmetro para as análises aqui realizadas. Em seguida, apresentamos os dados da distribuição de negros e brancos nos distintos espaços do Município, identificados segundo a classificação proposta.

Dentro de uma proposta de questionar e debater com o chamado "modelo radialconcêntrico" de estruturação urbana da metrópole de São Paulo, que tem uma imagem da metrópole calcada num gradiente decrescente de indicadores - renda, bem-estar, serviços e equipamentos públicos - do centro para a periferia, pesquisas associadas ao CEM propuseram uma mudança de escala de análise, antes realizada através dos dados de distritos ou de médias de círculos concêntricos e que passa, então, a basear-se nas áreas de ponderação (AP).

Esta mudança de escala trouxe um ganho na riqueza de detalhes para a localização espacial dos dados da metrópole, visto que as AP são unidades bem menores que os distritos, passando a ser possível, assim, uma maior aproximação dos conteúdos heterogêneos do espaço urbano. Levando em consideração esta 
heterogeneidade, as áreas de ponderação da Região Metropolitana de São Paulo foram classificadas a partir do seguinte procedimento:

Os dados da amostra do censo, submetidos a métodos estatísticos de análise fatorial, indicaram que as variáveis de renda domiciliar mensal média e taxa de crescimento demográfico anual para cada área de ponderação representam uma síntese do padrão de distribuição das outras variáveis, tais como: renda, escolaridade, migração recente, desemprego, falta de infra-estrutura urbana, presença de pretos e pardos, crescimento demográfico, etc. Sintetizam no sentido de que expressam conjuntos de fenômenos altamente associados a elas. Como exemplo, poderíamos citar o seguinte contraste: enquanto a renda está altamente associada à escolaridade e a raça, crescimento demográfico se relaciona com variáveis de precariedade urbana (como cobertura de saneamento básico) e migração recente. As duas variáveis-síntese foram submetidas a uma análise de cluster manual através da qual foram cruzados os quintis de renda domiciliar média e taxa de crescimento demográfico (Cf. Marques e Torres 2005).

A partir desta operação produziu-se uma tipologia na qual as áreas de ponderação foram classificadas em dez grupos, os quais revelam um continuum de posições sócio-econômicas e condições urbanas. Os grupos de áreas de ponderação 1 a 3, que concentram a população de classe baixa, foram reunidos sob a denominação de "periferias", os grupos de 4 a 7 foram chamados de "áreas intermediárias" ou "áreas de classe média", e os grupos de 8 a 10 de "áreas de elite". Esta classificação mostra que apesar da constatação da heterogeneidade das periferias, prevalece, portanto, o posicionamento de que as áreas periféricas concentram a população pobre e se caracterizam pela urbanização mais precária. Na Tabela 9 temos a descrição de algumas das características de cada um desses grupos. 


\begin{tabular}{|c|c|c|c|c|c|c|c|}
\hline \multicolumn{8}{|c|}{ Tabela 9 - Classificação por Grupos de Áreas de Ponderação do Município de São Paulo } \\
\hline $\begin{array}{l}\text { Tipo de } \\
\text { Área }\end{array}$ & Grupo & Denominação / Descrição & $\begin{array}{l}\text { Média de } \\
\text { Renda } \\
\text { Domiciliar } \\
\text { (em SM) }\end{array}$ & $\begin{array}{l}\text { Média de Anos } \\
\text { de Estudo do } \\
\text { Chefe }\end{array}$ & $\begin{array}{l}\text { Taxa de Crescimento } \\
\text { Demográfico (ao ano } \\
\text { 1991/2000) }\end{array}$ & $\begin{array}{l}\text { População } \\
\text { Total }\end{array}$ & $\begin{array}{l}\text { Quantidade } \\
\text { de Áreas de } \\
\text { Ponderação }\end{array}$ \\
\hline \multirow{3}{*}{$\begin{array}{l}\text { Áreas } \\
\text { Periféricas }\end{array}$} & 1 & $\begin{array}{l}\text { Muito pobres em intensa expansão } \\
\text { ou periferia de fronteira }\end{array}$ & 5,4 & 5,42 & 7,82 & 1.318 .121 & 47 \\
\hline & 2 & $\begin{array}{l}\text { Muito pobres em área precária em } \\
\text { crescimento ou periferia em } \\
\text { crescimento }\end{array}$ & 6,1 & 5,64 & 2,71 & 1.558 .725 & 55 \\
\hline & 3 & $\begin{array}{l}\text { Muito pobres em área precária, mas } \\
\text { consolidada ou periferia } \\
\text { estabilizada }\end{array}$ & 6,7 & 5,83 & 0,44 & 997.369 & 39 \\
\hline \multirow{4}{*}{$\begin{array}{l}\text { Áreas } \\
\text { Intermediár } \\
\text { ias }\end{array}$} & 4 & $\begin{array}{l}\text { Classe média baixa pobre em } \\
\text { crescimento em áreas precárias }\end{array}$ & 9,3 & 6,75 & 3,45 & 571.721 & 24 \\
\hline & 5 & Classe média baixa em crescimento & 10,7 & 7,16 & 0,60 & 1.050 .849 & 44 \\
\hline & 6 & $\begin{array}{l}\text { Classe média baixa em } \\
\text { esvaziamento }\end{array}$ & 11,7 & 7,50 & $-1,19$ & 2.483 .200 & 118 \\
\hline & 7 & Classe média sem crescimento & 18,1 & 9,06 & $-0,02$ & 968.492 & 49 \\
\hline \multirow{3}{*}{$\begin{array}{l}\text { Áreas de } \\
\text { Elite }\end{array}$} & 8 & Classe média-alta em esvaziamento & 28,5 & 10,82 & $-1,25$ & 697.928 & 36 \\
\hline & 9 & Classe alta em esvaziamento & 43,3 & 12,51 & $-1,76$ & 657.479 & 37 \\
\hline & 10 & Classe alta em áreas de expansão & 40,1 & 11,41 & 2,62 & 131.662 & 7 \\
\hline Total & & & 12,7 & 7,30 & 2,12 & 10.435 .546 & 456 \\
\hline
\end{tabular}


Da análise da distribuição dos grupos no espaço da Região Metropolitana de São Paulo, Marques (2005b) conclui que, apesar de os grupos de 1 a 3 tenderem a se concentrar na porção externa da metrópole e os grupos de 8 a 10 na região central, o modelo de estruturação radial-concêntrico se sustenta apenas se considerado como uma descrição genérica, uma aproximação. Isso porque notam-se diversas concentrações de alta renda fora do núcleo central, além de uma grande complexidade na distribuição dos grupos mais pobres, que apresenta algumas mesclas com áreas de alta e média renda, não sendo, portanto, tão coerente com a descrição do gradiente centro-periferia.

$\mathrm{Na}$ análise que faremos a seguir, a classificação realizada por Marques (2005b) será considerada tendo em vista apenas o Município de São Paulo. ${ }^{36}$

O Mapa 2 mostra a classificação das áreas de ponderação do município de São Paulo segundo os três tipos resultantes da reunião dos 10 grupos iniciais - áreas de elite, áreas intermediárias e áreas periféricas -, e pode ilustrar no nível do município parte das conclusões de Marques (2005b) sobre a Região Metropolitana.

As áreas classificadas como de elite concentram-se principalmente no chamado "quadrante sudoeste", configurando uma mancha que inicia em distritos que margeiam o "centro velho" da cidade - como Consolação e áreas da Bela Vista e da Liberdade - e vai às direções oeste e sul da cidade - tendo como extremos áreas dos distritos do Butantã, Vila Sônia, Vila Andrade e Santo Amaro. Além desta grande concentração, há ainda pequenos agrupamentos de áreas de elite na parte leste da Zona Norte - nos distritos de Santana, Mandaqui, Tucuruvi e Tremembé - e no inicio da Zona Leste - nos distritos da Mooca, Tatuapé e Vila Formosa. As áreas classificadas como periféricas localizam-se nos distritos mais extremos das regiões norte, oeste e sul. As áreas intermediárias, de modo geral, envolvem as áreas de elite, localizando-se entre estas e as periféricas, como se fizessem o papel de uma região de transição. Raras são as áreas de elite que se avizinham de áreas periféricas.

Partindo da classificação proposta e considerando que a população paulistana é composta por $67 \%$ de brancos e $30 \%$ de negros, podemos observar a distribuição de negros e brancos nos distintos tipos de áreas do município nas tabelas a seguir.

A Tabela 10 mostra que a população branca tem maior concentração nas áreas intermediárias (52\%), com uma proporção muito maior que a dos negros nas áreas de

\footnotetext{
${ }^{36}$ A análise desta pesquisa se restringirá ao município porque diversos outros municípios da Região Metropolitana são compostos por apenas uma ou por muito poucas áreas de ponderação, causando distorções para o cálculo dos índices.
} 


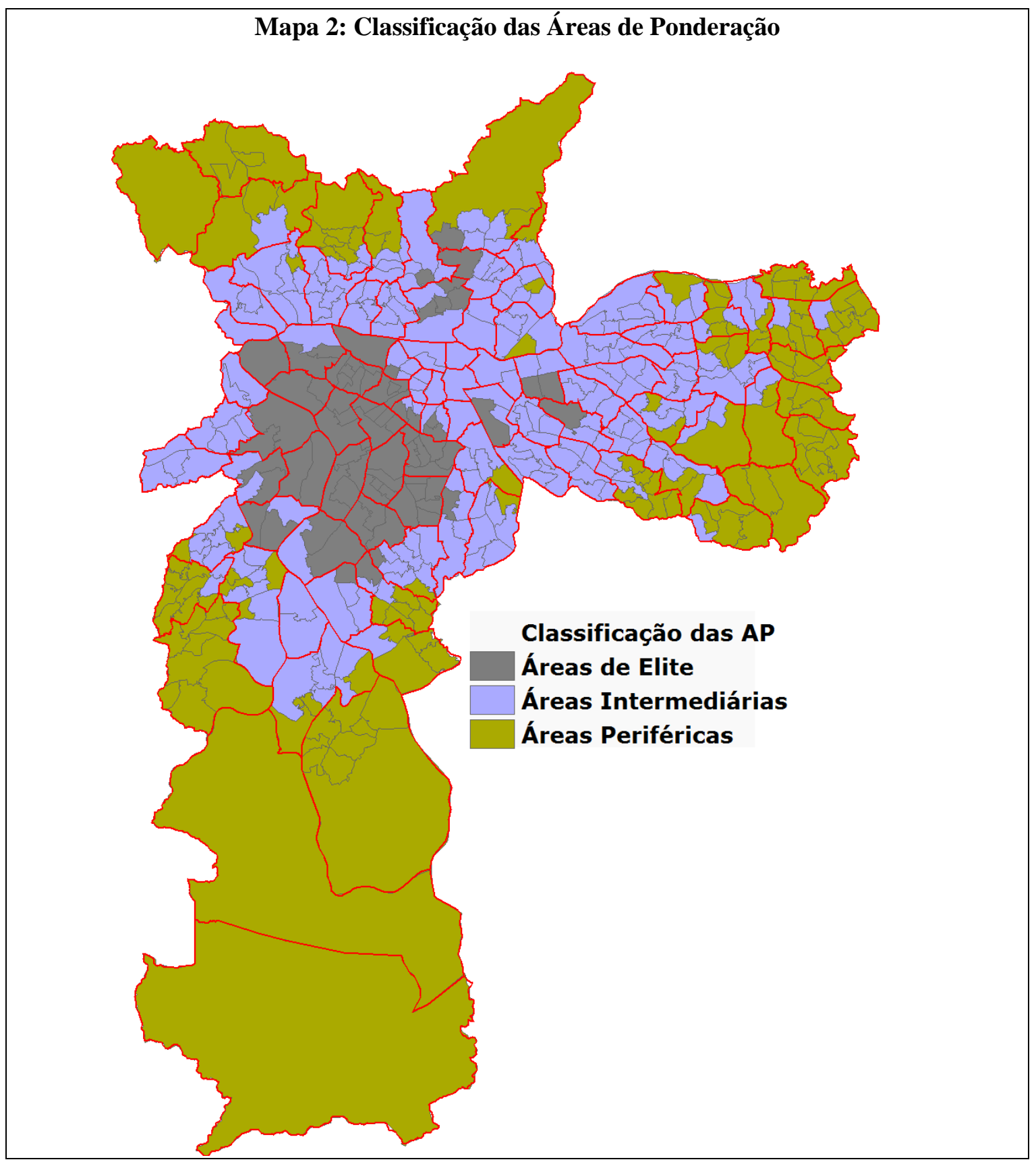

\begin{tabular}{|ccccc|}
\hline \multicolumn{5}{|c|}{$\begin{array}{c}\text { Tabela 10 - Distribuição dos grupos de raça/cor por Tipo } \\
\text { de Área de Ponderação (2000) }\end{array}$} \\
\hline Tipo de área & Brancos & Negros & Outros $^{1}$ & Total \\
\hline Elite & $18,2 \%$ & $3,9 \%$ & $46,7 \%$ & $26,8 \%$ \\
\hline Intermediária & $52,0 \%$ & $40,2 \%$ & $49,8 \%$ & $54,0 \%$ \\
\hline Periférica & $29,8 \%$ & $55,9 \%$ & $3,5 \%$ & $19,2 \%$ \\
\hline Total & $\mathbf{1 0 0 , 0 \%}$ & $\mathbf{1 0 0 , 0 \%}$ & $\mathbf{1 0 0 , 0 \%}$ & $\mathbf{1 0 0 , 0 \%}$ \\
\hline
\end{tabular}

Outros: corresponde a soma de: amarelos, indígenas e ignorados.

Fonte: Amostra do Censo de 2000 / IBGE 
elite $(18,2 \%$ contra $3,9 \%)$ e um pouco maior nas áreas intermediárias. Por outro lado, vemos que mais da metade da população negra do município de São Paulo $(55,9 \%)$ reside em áreas periféricas e uma quantidade muito expressiva $(40,2 \%)$, nas áreas intermediárias. ${ }^{37}$

A Tabela 11 compara a composição de cada tipo de áreas por raça/cor. A tabulação mostra que os negros têm concentração acima da média global do município (30\%) nas áreas periféricas, enquanto as áreas intermediárias e de elite são ocupadas predominantemente por brancos.

A partir desses dados, podemos considerar as áreas de elite como espaços de segregação de brancos e, as áreas periféricas, como espaços de grande mistura entre brancos e negros.

Essa tendência pode ser mais bem detalhada através do Mapa 3, que apresenta a proporção de negros para cada área de ponderação. Neste mapa notamos que as áreas com mais de $30 \%$ de negros (ou seja, onde os negros estão sobre-representados) encontram-se nas bordas da cidade. Comparando os mapas, podemos perceber que quase todas as áreas do Mapa 3 com mais de $45 \%$ de negros em sua população estão classificadas como periféricas no Mapa 2.

Através da Tabela 12, notamos que a proporção de negros reduz progressivamente das áreas mais pobres para as áreas mais ricas - de 45,57\% no grupo 1 para $6,57 \%$ no grupo 9. A proporção aumenta novamente, contudo, no grupo 10 , pois esse grupo reúne as áreas de ponderação nas quais se encontram os territórios onde ocorrem processos de expansão imobiliária para alta renda, não sendo, ainda, áreas consolidadas das classes altas. (Marques 2005b)

Marques (2005b) já havia evidenciado que os grupos 1 a 4, mais periféricos, são os que apresentam alta incidência de pretos e pardos e de migrantes nordestinos, além de altas taxas de desemprego. Apesar de esses grupos apresentarem a proporção de negros acima da proporção global do município, em média, nenhum deles traz uma proporção de negros acima de $50 \%$.

De todas as 456 áreas de ponderação de São Paulo, 35 (7,6\%) têm mais de 50\% de negros, sendo todas elas áreas periféricas: 20 do grupo 1, 9 do grupo 2 e 6 do grupo 3. A área de ponderação com maior proporção de negros é a do Jardim Capela II, no

\footnotetext{
37 A grande concentração de "outros" nas áreas de elite e intermediárias deve-se ao fato de $2 / 3$ deste grupo ser composto pelos amarelos, com grande concentração nestes tipos de áreas.
} 


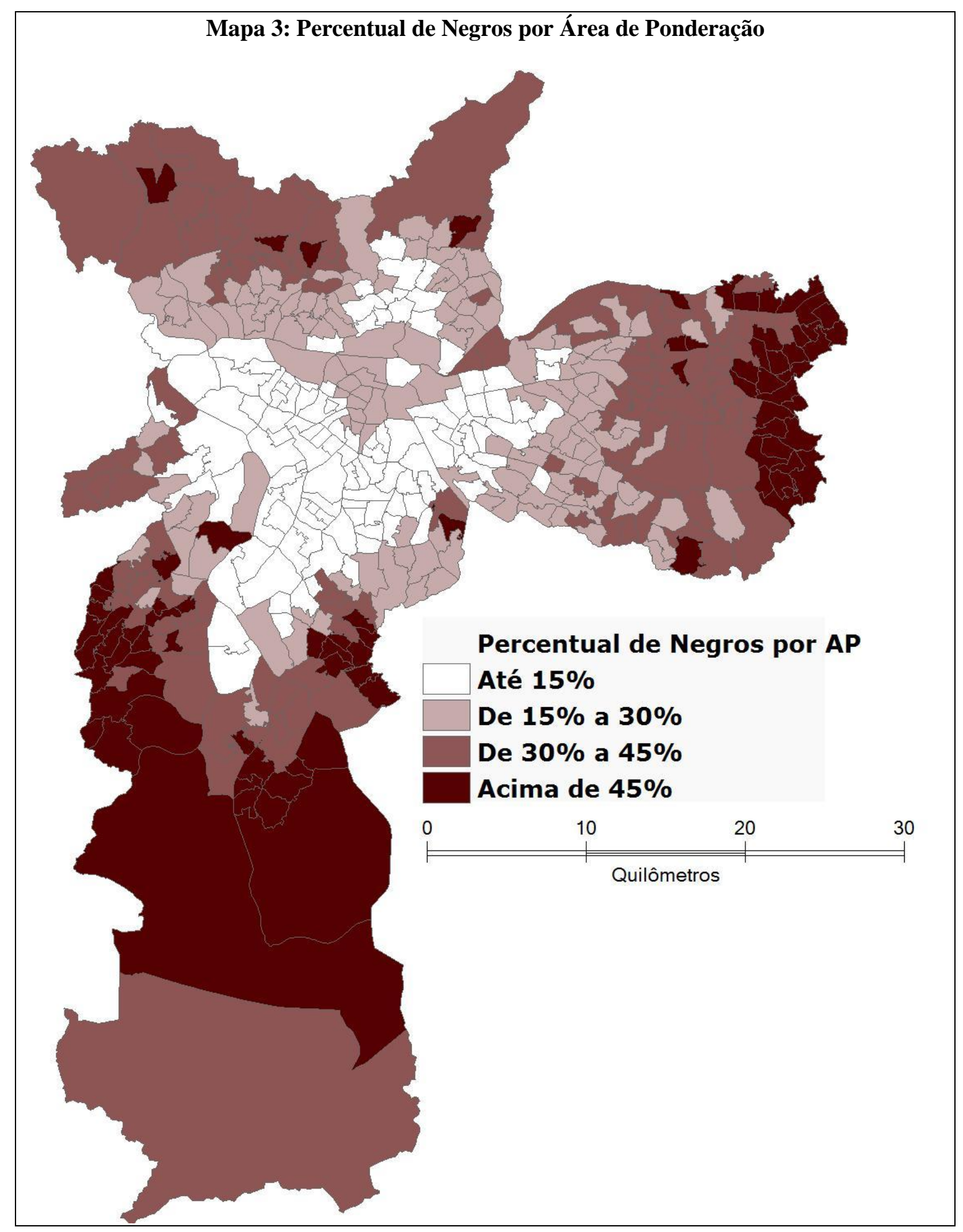




\begin{tabular}{|ccccc|}
\hline \multicolumn{2}{|c|}{ Tabela 11 - População Total das Áreas Distribuídas por Raça/Cor (2000) } \\
\hline Raça/Cor & Áreas de Elite & Áreas Intermediárias & Áreas Periféricas & Total \\
\hline Brancos & $86,0 \%$ & $71,7 \%$ & $53,5 \%$ & $67,0 \%$ \\
\hline Negros & $8,5 \%$ & $24,9 \%$ & $45,0 \%$ & $30,0 \%$ \\
\hline Outros & $5,5 \%$ & $3,4 \%$ & $1,5 \%$ & $3,0 \%$ \\
\hline Total & $\mathbf{1 0 0 , 0 \%}$ & $\mathbf{1 0 0 , 0 \%}$ & $\mathbf{1 0 0 , 0 \%}$ & $\mathbf{1 0 0 , 0 \%}$ \\
\hline
\end{tabular}

1 Outros: corresponde a soma de: amarelos, indígenas e ignorados.

Fonte: Amostra do Censo de 2000 / IBGE

\begin{tabular}{|l|l|l|}
\hline \multicolumn{3}{|c|}{$\begin{array}{c}\text { Tabela 12 - Proporção de negros por } \\
\text { grupos de áreas de ponderação (2000) }\end{array}$} \\
\hline Tipo das Áreas & Grupos & \% de Negros \\
\hline \multirow{4}{*}{ Periféricas } & 1 & $45,5 \%$ \\
\cline { 2 - 3 } & 2 & $43,2 \%$ \\
\cline { 2 - 3 } & 3 & $40,6 \%$ \\
\hline \multirow{4}{*}{ Intermediárias } & 4 & $34,0 \%$ \\
\cline { 2 - 3 } & 5 & $28,8 \%$ \\
\cline { 2 - 3 } & 6 & $22,2 \%$ \\
\cline { 2 - 3 } & 7 & $17,2 \%$ \\
\hline \multirow{3}{*}{ De Elite } & 8 & $10,3 \%$ \\
\cline { 2 - 3 } & 9 & $6,5 \%$ \\
\cline { 2 - 3 } & 10 & $11,9 \%$ \\
\hline Total & $\mathbf{3 0 , 0 \%}$ \\
\hline Fonte: Amostra do Censo de $2000 /$ IBGE & \\
\hline
\end{tabular}

distrito do Jardim Ângela, classificada como grupo 1 e com 58,2\% de negros. Há 11 áreas de ponderação com menos de $5 \%$ de negros, todas de elite, com a menor proporção, de 3,8\%, verificada na AP Moema-Bandeirantes II, no distrito de Moema, classificada como grupo 10.

Até aqui demonstramos para a cidade de São Paulo as mesmas conclusões gerais dos estudos de Costa e Ribeiro (2004), Ribeiro (2007), Garcia (2006) e Carvalho e Barreto (2007) sobre outras metrópoles brasileiras: a população negra apresenta maior concentração nas áreas mais pobres, e menor concentração nas áreas ricas. 
Tal constatação pode nos levar à sentença já apontada também por esses autores: de que a presença negra é maior em áreas pobres porque a proporção de negros entre os pobres é maior. Entretanto, essa hipótese não pode ser corroborada pelos dados mostrados acima, pois eles não nos permitem avaliar a associação entre raça, classe e espaço, mas apenas entre raça e espaço. Portanto, pretendemos avançar a partir da consideração da forma como se distribuem as populações branca e negra posicionadas nos mesmos estratos sociais no Município de São Paulo.

A comparação das distribuições de negros e brancos pertencentes às mesmas faixas de renda pelos diferentes tipos de áreas da cidade pode ser observada nas tabelas 13 e 14.

Os dados das tabelas 13 e 14 demonstram que a população branca na faixa entre 10 e 20 salários-mínimos distribui-se da seguinte maneira: 16,3\% em áreas de elite, 62,5\% em áreas intermediárias e 21,2\% em áreas periféricas. Enquanto os negros desse mesmo estrato apresentam a seguinte distribuição: 5,6\% em áreas de elite, 52\% em áreas intermediárias e 42,4\% em áreas periféricas. Apesar da maior concentração de ambos em áreas intermediárias, a proporção de negros dessa faixa de renda em áreas periféricas é o dobro da proporção de brancos.

Comparando a distribuição por áreas entre negros e brancos dentro da faixa de renda acima de 20 salários-mínimos, os negros concentram-se mais nas áreas intermediárias (57\%), com o restante quase dividindo-se entre áreas periféricas $(22,4 \%)$ e de elite (20,2\%). Já os brancos desse estrato dividem-se entre áreas de elite e intermediárias (47,1\% em cada), com apenas 5,8\% em áreas periféricas. É importante enfatizar que aqui estamos comparando proporções da distribuição de negros e brancos em cada tipo de área.

Os dados apresentados demonstram que os negros nas faixas de renda mais alta têm maior concentração nas áreas periféricas de São Paulo que os brancos nas mesmas faixas de renda. Está indicado, assim, um maior grau de segregação racial nas faixas de renda mais altas, uma vez que os negros de alta renda têm maior concentração em áreas mais pobres e com mais negros. De igual maneira, pode-se depreender que as áreas de elite são espaços segregados, na medida em que concentram a população branca. 


\begin{tabular}{|c|c|c|c|c|c|c|c|}
\hline \multicolumn{8}{|c|}{$\begin{array}{c}\text { Tabela } 13 \text { - Distribuição dos Negros e Brancos segundo Faixas de Renda Domiciliar (em SM) } \\
\text { e Tipo de Área de Ponderação (2000) }\end{array}$} \\
\hline \multirow{2}{*}{$\begin{array}{l}\text { Raça / } \\
\text { Cor }\end{array}$} & \multirow[b]{2}{*}{ Tipo de Área } & \multicolumn{6}{|c|}{ Faixas de Renda Domiciliar (em SM) } \\
\hline & & & Até 5 SM & $\begin{array}{l}\text { De } 5 \text { a } 10 \\
\text { SM }\end{array}$ & $\begin{array}{l}\text { De } 10 \text { a } 20 \\
\text { SM }\end{array}$ & $\begin{array}{l}\text { Acima de } \\
20 \mathrm{SM}\end{array}$ & Total \\
\hline \multirow{8}{*}{ Brancos } & \multirow{2}{*}{ Elite } & Contagem & 103.403 & 157.469 & 248.091 & 759.680 & 1.268 .643 \\
\hline & & $\%$ & $5,1 \%$ & $8,7 \%$ & $16,3 \%$ & $47,1 \%$ & $18,2 \%$ \\
\hline & \multirow{2}{*}{ Intermediária } & Contagem & 914.430 & 992.697 & 951.481 & 758.989 & 3.617 .597 \\
\hline & & $\%$ & $45,2 \%$ & $55,1 \%$ & $62,5 \%$ & $47,1 \%$ & $52,0 \%$ \\
\hline & \multirow{2}{*}{ Periférica } & Contagem & 1.003 .172 & 651.257 & 323.343 & 94.118 & 2.071 .890 \\
\hline & & $\%$ & $49,6 \%$ & $36,2 \%$ & $21,2 \%$ & $\mathbf{5 , 8 \%}$ & $\mathbf{2 9 , 8 \%}$ \\
\hline & \multirow{2}{*}{ Total } & Contagem & 2.021 .005 & 1.801 .423 & 1.522 .915 & 1.612 .787 & 6.958 .130 \\
\hline & & $\%$ & $100,0 \%$ & $100,0 \%$ & $100,0 \%$ & $100,0 \%$ & $100,0 \%$ \\
\hline \multirow{8}{*}{ Negros } & \multirow{2}{*}{ Elite } & Contagem & 32.598 & 29.913 & 25.942 & 34.649 & 123.102 \\
\hline & & $\%$ & $2,1 \%$ & $3,2 \%$ & $5,6 \%$ & $20,2 \%$ & $3,9 \%$ \\
\hline & \multirow{2}{*}{ Intermediária } & Contagem & 516.119 & 398.487 & 240.341 & 98.056 & 1.253 .003 \\
\hline & & $\%$ & $33,6 \%$ & $42,1 \%$ & $52,0 \%$ & $57,3 \%$ & $40,2 \%$ \\
\hline & \multirow{2}{*}{ Periférica } & Contagem & 988.953 & 518.062 & 195.803 & 38.404 & 1.741 .222 \\
\hline & & $\%$ & $64,3 \%$ & $54,7 \%$ & $42,4 \%$ & $22,4 \%$ & $55,9 \%$ \\
\hline & \multirow{2}{*}{ Total } & Contagem & 1.537 .670 & 946.462 & 462.086 & 171.109 & 3.117 .327 \\
\hline & & $\%$ & $100,0 \%$ & $100,0 \%$ & $100,0 \%$ & $100,0 \%$ & $100,0 \%$ \\
\hline
\end{tabular}

Tabela 14 - Distribuição de negros, brancos e outros segundo Faixas de Renda Domiciliar (em SM) e Tipo de Área de Ponderação (2000)

\begin{tabular}{|rlrrrr|}
\hline \multirow{2}{*}{$\begin{array}{c}\text { Faixas de Renda } \\
\text { Domiciliar (em SM) }\end{array}$} & Tipos de Área & \multicolumn{3}{c}{ Raça / Cor } & \multirow{2}{*}{ Total } \\
\cline { 3 - 5 } & Elite & $16,3 \%$ & $5,6 \%$ & $23,5 \%$ & $14,1 \%$ \\
\cline { 2 - 5 } De 10 a 20 SM & Intermediária & $62,5 \%$ & $52,0 \%$ & $62,6 \%$ & $60,1 \%$ \\
\cline { 2 - 5 } & Periférica & $21,2 \%$ & $42,4 \%$ & $14,0 \%$ & $25,8 \%$ \\
\cline { 2 - 5 } & Total & $\mathbf{1 0 0 , 0 \%}$ & $\mathbf{1 0 0 , 0 \%}$ & $\mathbf{1 0 0 , 0 \%}$ & $\mathbf{1 0 0 , 0 \%}$ \\
\hline \multirow{2}{*}{ Acima de 20 SM } & Elite & $47,1 \%$ & $20,2 \%$ & $46,7 \%$ & $44,7 \%$ \\
\cline { 2 - 5 } & Intermediária & $47,1 \%$ & $57,3 \%$ & $49,8 \%$ & $48,1 \%$ \\
\cline { 2 - 5 } & Periférica & $5,8 \%$ & $22,4 \%$ & $3,5 \%$ & $7,2 \%$ \\
\cline { 2 - 5 } & Total & $\mathbf{1 0 0 , 0 \%}$ & $\mathbf{1 0 0 , 0 \%}$ & $\mathbf{1 0 0 , 0 \%}$ & $\mathbf{1 0 0 , 0 \%}$ \\
\hline
\end{tabular}




\subsection{Análise do quociente locacional}

O quociente locacional (QL) é um método tradicional e largamente empregado nos estudos de economia regional. Em geral, é utilizado com a finalidade de identificar o grau de especialização de determinadas regiões em um dado setor da economia ou para localizar as regiões onde ocorre maior concentração de um determinado setor. (Cf. Simões 2005)

Aqui, aplicaremos o QL para identificar áreas de ponderação do município onde certos grupos estão sobre-representados ou sub-representados.

O quociente locacional consistirá na razão entre a proporção da população de um grupo em uma determinada área e a proporção da população deste mesmo grupo na cidade inteira, segundo a fórmula a seguir:

$$
Q L=\frac{\left(x_{i} / t_{i}\right)}{(X / T)}
$$

No numerador, temos a razão entre a população de um dado grupo (X) em uma área i sobre a população total desta área (Ti); no denominador, dividimos todo o contingente populacional deste grupo na cidade $(\mathrm{X})$ pela população total da cidade $(\mathrm{T})$.

Assim, se, por exemplo, um determinado grupo representa $20 \%$ da população da cidade, mas representa $10 \%$ da população de uma determinada área. Para esta unidade espacial, quociente locacional será obtido através da razão entre $0,10 / 0,20$, resultando em 0,5 .

Se o valor do quociente locacional estiver no intervalo entre 0 e 1 , isto indica que o grupo em consideração está sub-representado na área observada. E quanto mais próximo de 0, mais sub-representado está o grupo. Se o valor do QL é próximo de 1, acima ou abaixo, naquela área o grupo em análise tem proporção próxima da sua proporção para toda a cidade. Acima de 1, quanto maior for o resultado do QL, mais sobre-representado estará o grupo em uma determinada área. Em suma, quanto maior o valor do QL maior a concentração de um dado grupo na área em análise.

Diferentemente do índice de dissimilaridade, que resulta num indicador único para toda a cidade, o quociente locacional resultará em valores para cada uma das áreas 
de ponderação da cidade. O que nos permite comparações entre diferentes áreas da cidade e identificação de tendências intra-urbanas.

Para cada área de ponderação do município, calculamos os quocientes locacionais dos negros e dos brancos, e também os QL de negros e brancos em cada uma das faixas de renda adotadas como referência neste texto. ${ }^{38}$ Nesta seção, recorreremos a duas abordagens para análise destes quocientes locacionais: primeiramente, analisaremos as correlações estatísticas entre os QL de negros e brancos em cada uma das faixas de renda; e, em seguida, faremos análise comparativa dos QL médios de negros e brancos em cada uma das faixas de renda para os 10 grupos de áreas de ponderação definidos pelas pesquisas do CEM-CEBRAP, e apresentados na seção anterior.

Consideremos, então, o resultado das correlações de Pearson, na tabela a seguir. Os coeficiente de correlação podem variar entre 1 e -1 . Quanto mais próximo de 1 for o valor do coeficiente, maior a tendência das duas variáveis em análise serem diretamente proporcionais, ou seja, quando uma for alta, a outra também será. Quando o resultado for um valor negativo, indica correlação negativa, ou seja, quando os valores de uma variável aumentam, os valores da outra tendem a diminuir. Valores próximos de zero indicam ausência de correlação linear entre as veriáveis.

\begin{tabular}{|l|c|}
\hline \multicolumn{2}{|l|}{ Tabela 15 - Correlações entre os quocientes locacionais de } \\
negros e brancos nas quatro das faixas de renda domiciliar. \\
\hline Até 5 salários-mínimos & $0,801 * *$ \\
\hline De 5 a 10 salários-mínimos & $0,205 * *$ \\
\hline De 10 a 20 salários-mínimos & $-0,199 * *$ \\
\hline Acima de 20 salários-mínimos & $0,480 * *$ \\
\hline$* *$ p-valor $>0,01$ & \\
\hline
\end{tabular}

Para a faixa de renda até 5 salários-mínimos, o valor do coeficiente de correlação é bem alto - 0,801 - indicando uma tendência de que onde há altos valores do QL para brancos deste estrato também haverá para negros.

\footnotetext{
${ }^{38}$ Ou seja, para cada área de ponderação, calculamos 10 quocientes locacionais: dos negros, dos brancos, dos negros na faixa de renda até 5 salários-mínimos, dos brancos na faixa de renda até 5 saláriosmínimos, dos negros na faixa de renda de 5 a 10 salários-mínimos, dos brancos na faixa de renda de 5 a 10 salários-mínimos, dos negros na faixa de renda de 10 a 20 salários-mínimos, dos brancos na faixa de renda de 10 a 20 salários-mínimos, dos negros na faixa de renda acima de 20 salários-mínimos, dos brancos na faixa de renda acima 20 salários-mínimos,
} 
Na faixa de renda seguinte, entre 5 e 10 salários mínimos, a correlação entre os QLs de negros e brancos é fraca, de 0,205.

Já na faixa de renda entre 10 e 20 salários-mínimos, surpreende o fato de que há uma correlação negativa entre os quocientes locacionais de negros e brancos, que a despeito de ser fraca, indica uma tendência de que nas áreas onde os brancos desta faixa de renda têm altos quocientes locacionais,os negros terão baixos valores, e vice-e-versa. Ou seja, os dois grupos raciais, pertencentes a esta mesma faixa de renda, tendem a ter maiores concentrações em áreas diferentes.

$\mathrm{Na}$ faixa de renda domiciliar mais alta, acima de 20 salários-mínimos, o coeficiente de correlação de Pearson é positivo e moderado: 0,480.

A partir dos resultados revelados pelos coeficientes de correlações de Pearson, podemos deduzir que na faixa de renda mais baixa, negros e brancos tendem residir muito próximos uns dos outros, pois os valores de seus QLs são próximos nas mesmas áreas de ponderação. Já na faixa seguinte, de 5 até 10 salários-mínimos, esta tendência cai bastante. Na faixa de renda domiciliar entre 10 e 20 salários-mínimos, os QLs de negros e brancos exibem tendências opostas nas áreas de ponderação, ou seja, cada grupo tende a estar sobre-representados em diferentes áreas. Os dois grupos raciais voltam a estar mais próximos na faixa de renda mais alta, mas a correlação é cerca de metade da verificada na faixa mais baixa.

Os gráficos a seguir exibem as médias dos QLs de negros e brancos para cada um dos 10 grupos de áreas de ponderação propostos pela classificação aplicada na seção anterior. ${ }^{39}$ A análise dos gráficos nos permitirá verificar em que tipo de área os valores dos quocientes locacionais de cada grupo aumenta ou diminui.

O primeiro gráfico (Gráfico 8) exibe as médias do QL de negros e brancos. A linha vermelha, que descreve os valores dos brancos, exibe uma suave tendência de crescimento, apresentando valores próximos de 1 para a maior parte dos grupos, com exceção dos áreas dos grupos acima de 7, que apresentam valores médios maiores que 1,2. Já a linha azul, representando as médias dos quocientes locacionais dos negros,

\footnotetext{
${ }^{39}$ Convém lembrar que os grupos de 1 a 3 foram classificados como "áreas periféricas", os grupos 4 a 7 como "intermediárias", e os grupos 8 a 10 como "áreas de elite".
} 

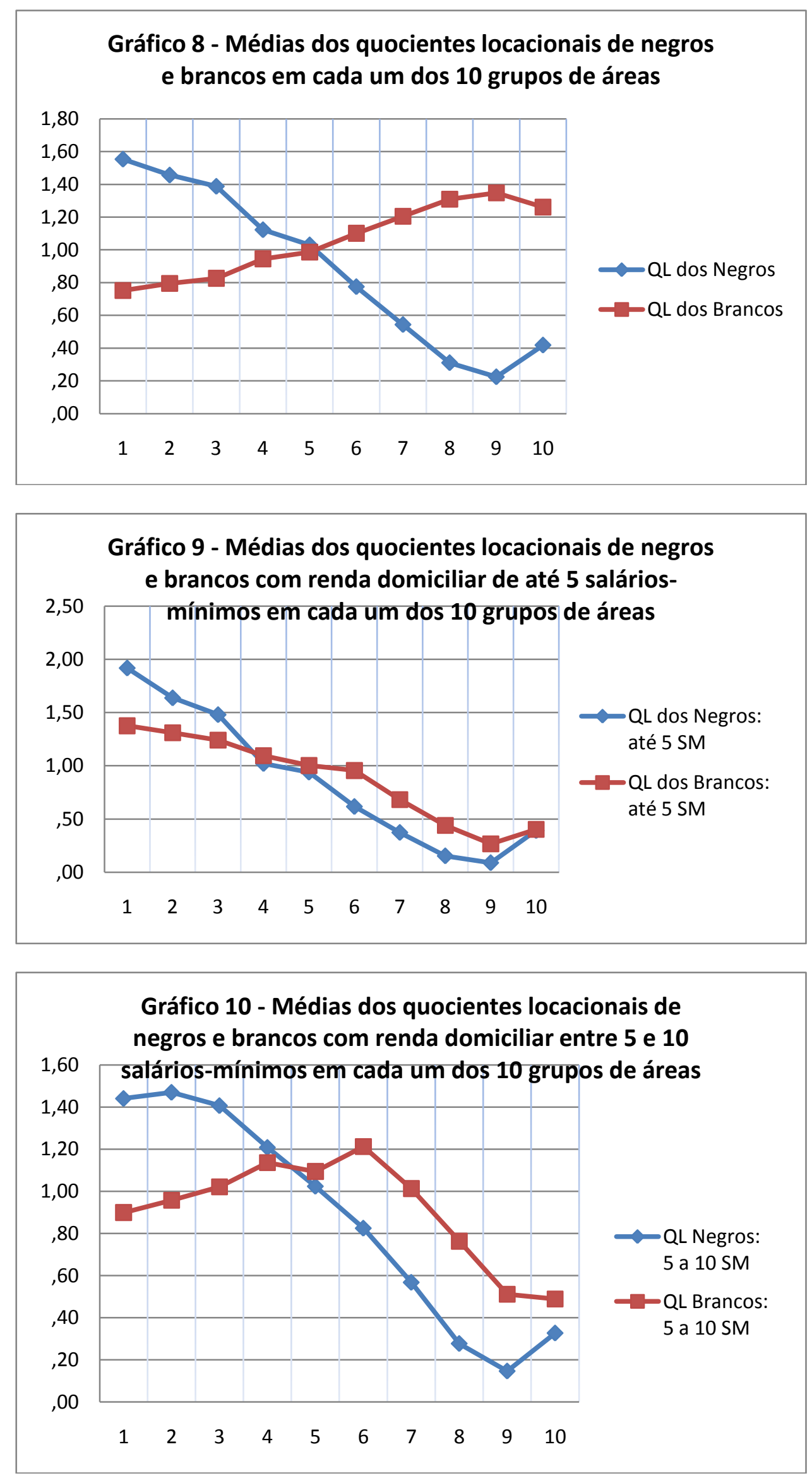

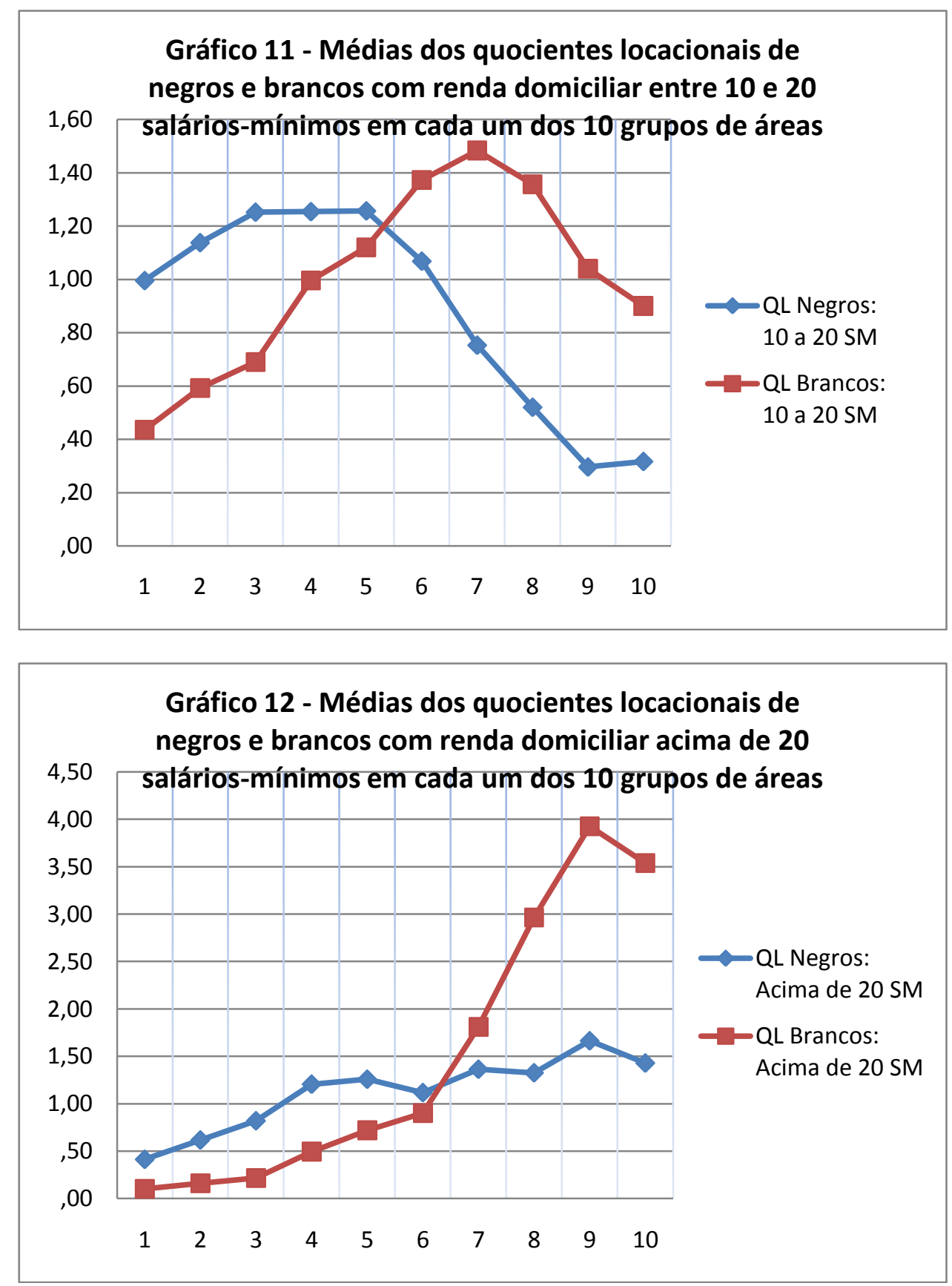
apresenta um agudo decrescimento, com valores acima de 1,20 para as áreas dos grupos 1, 2 e 3, e abaixo de 0,6 para os grupos acima de 7. Isto demonstra que os brancos têm uma distribuição bem uniforme por quase toda a cidade (ou seja, a proporção de brancos em nas áreas se aproxima da proporção de brancos para a cidade como um todo), estando mais sobre-representados nas áreas mais ricas. Já os negros não estão distribuídos tão uniformemente assim: são muito sobre-representados nas áreas mais pobres e muito sub-representados nas áreas mais ricas.

Considerando a faixa de renda domiciliar mais baixa (Gráfico 9) percebemos que as linhas de negros e brancos decrescem em direção aos grupos de áreas mais ricas. A proximidade entre as duas linhas do gráfico nos permite ter uma idéia da proximidade residencial entre negros e brancos da faixa de renda mais baixa: em geral, estão sobrerepresentados nos mesmos tipos de áreas (grupos 1 a 5). Entretanto, o decrescimento do QL dos brancos é mais suave enquanto que o dos negros é muito mais agudo. Além disso, o valor do quociente locacional dos negros é maior que o dos brancos nos grupos 1, 2 e 3, enquanto que a partir do grupo 4, o valor do QL dos brancos é sempre maior que o dos negros. Ou seja, quanto mais rica é a área menor a presença de pessoas da faixa de renda mais baixa, sejam elas brancas ou negras. Mas, mesmo assim, a presença de brancos pobres supera a de negros pobres nas áreas ricas.

Na faixa de renda de 5 a 10 salários-mínimos (Gráfico 10), observamos, para os brancos, uma linha quase estável e próxima de 1 entre os grupos 1 a 7 . Ou seja, nestas áreas, os brancos desta faixa de renda têm uma representação semelhante à proporção de brancos para a cidade como um todo. Esta linha cresce suavemente até o grupo 6. Daí em diante ela decresce para valores bem abaixo de 1 conforme avançamos para os grupos de áreas mais ricas. A linha azul dos negros apresenta altos valores do QL (acima de 1,4) nos três grupos periféricos, indicando sobre-representação dos negros desta faixa de renda nestas áreas. A partir do grupo 4 os valores decrescem agudamente em direção das áreas mais ricas.

Nos gráficos 9 e 10, das faixas de renda domiciliar mais baixas (até 5 saláriosmínimos e de 5 a 10 salários-mínimos), a linha azul (do quociente locacional dos negros) apresenta uma queda muito aguda, indicando uma sobre-representação muito forte nos primeiros grupos (áreas periféricas), caindo para uma sub-representação também muito forte nas áreas mais elitizadas. 
Como seria de se esperar após o resultado das correlações, na faixa de renda entre 10 e 20 salários-mínimos, observamos as maiores diferenças entre as médias dos quocientes locacionais de brancos e negros para cada grupo de áreas. Os negros desta faixa têm valor de QL acima de 1 (ou seja, estão sobre representados) nos grupos de 1 a 6; enquanto que os brancos estão sobre-representados nos grupos 4 a 9. Os menores valores para os brancos estão nos grupos de áreas periféricas (1, 2 e 3), e os menores valores para os negros estão nos grupos de áreas de elite $(8,9$ e 10).

Os negros na faixa de renda mais alta (Gráfico 12) têm quocientes locacionais médios maiores do que 1 nos grupos de 4 até 10. Os brancos desta faixa de renda só estão sobre-representados a partir do grupo 7, quando o seu QL dá um salto e passa a exibir valores altíssimos (todos acima de 1,5) até o grupo 10 . O valor médio máximo do QL para os negros deste estrato ocorre nas áreas do grupo 9, e é de 1,66. Neste mesmo grupo de áreas registramos o maior valor do QL dos brancos: 3,92.

Se nas faixas de renda mais baixas observamos que a linha azul foi a mais aguda, neste estrato mais alto a linha mais aguda é a vermelha, mas no sentido oposto. O quociente locacional dos brancos mais ricos é baixíssimo nas áreas periféricas e altíssimo nas áreas de elite.

Em todos os gráficos observamos um cruzamento entre a linha dos brancos (vermelha) e a dos negros (azul). A linha vermelha sempre inicia o gráfico abaixo da azul e o termina acima desta. Isto significa que, independentemente do estrato social (ou faixa de renda), o quociente locacional dos brancos é sempre menor que o dos negros nas áreas mais pobres e carentes de infra-estrutura, e maior que o dos negros nas áreas mais ricas e bem-servidas de amenidades urbanas. Ou seja, proporcionalmente à participação de cada um destes grupos na composição da população do município, sempre há mais brancos do que negros nas áreas mais ricas, seja qual for o estrato social dos indivíduos destes grupos raciais. E, inversamente, há mais negros (seja de classe alta ou baixa) nas áreas periféricas do que brancos.

A apresentação de mapas com a representação dos quocientes locacionais de cada área nos permitiria identificar quais são os espaços da cidade de maior representação de cada grupo. Entretanto, realizaremos este mesmo objetivo na seção seguinte, com a apresentação dos mapas resultantes do Índice de Moran Local, que apontam tendências semelhantes àquelas que poderiam ser verificadas nos mapas do quociente locacional, e são de mais fácil interpretação. 


\subsection{Análise dos mapas do Índice de Moran Local}

Outra medida de segregação que tem sido muito aplicada recentemente é o chamado índice de Moran. O índice de Moran é um indicador de autocorrelação espacial, ou seja, permite mensurar se a presença de um fenômeno em uma determinada área ocorre também em áreas vizinhas a esta, caracterizando agrupamentos de áreas (clusters) nas quais se observa a ocorrência de um mesmo fenômeno, ou nas quais observamos valores semelhantes de uma dada variável.

O Índice de Moran Global (I) ${ }^{40}$ resulta num valor único para todo o conjunto de dados da cidade. Este valor pode variar em -1 e 1. No caso da distribuição das ocorrências de uma dada variável estar aleatoriamente distribuída no espaço, ou seja, quando não houver dependência espacial, o valor do índice tenderá a zero. Valores positivos do índice indicam que os valores da variável em estudo tendem a ser semelhantes em áreas vizinhas, havendo autocorrelação espacial positiva. Valores negativos do índice indicam autocorrelação espacial negativa.

\footnotetext{
"(...) se comparado aos indicadores comumente utilizados nos estudos de segregação - como o índice de dissimilaridade - o Índice de Moran incorpora uma dimensão bastante inovadora: testar se há padrões similares de distribuição de uma certa variável (...) entre áreas vizinhas. Por exemplo, em situações onde não existe segregação, a distribuição da proporção de pobres (ou de qualquer outra variável de interesse, como concentração de negros) será uniforme em uma dada área e em seus vizinhos e o índice de Moran Global tenderá a zero. Para as situações onde há segregação, as áreas com altas concentrações de pobres serão vizinhas entre si (assim como as áreas com altas concentrações de não-pobres) e o Índice de Moran se aproximará de 1.” (Bichir 2006: 60-1)
}

Entretanto, o Índice de Moran Global, por fornecer um valor único para toda a cidade, não nos permite identificar diferenciais de autocorrelação espacial internos a

\footnotetext{
40 O cálculo do Índice de Moran Global é representado pela seguinte fórmula: $I=\frac{\sum_{i=1}^{\mathrm{n}} \sum_{j=1}^{\mathrm{n}}\left\lceil w_{i j}\left(z_{i}\right]-\bar{z}\right)\left(z_{j}-\bar{z}\right)}{\sum_{i-1}^{\mathrm{n}}\left(z_{i}-\bar{z}\right)^{2}}$.
}

"Na equação acima, $n$ é o número de áreas, $z i$ o valor do atributo considerado na área $i, \bar{z}$ é o valor médio do atributo na região de estudo e wij os elementos da matriz normalizada de proximidade espacial." (Câmara etal 2002: 14). Os valores da matriz de proximidade espacial, também chamada de "matriz de vizinhança", indicam se as áreas são contíguas ou não. 
esta área. Para examinar estes padrões com maior detalhe, Anselin (1995) propôs os chamados LISA (Local Indicators of Spatial Association, ou Indicadores Locais de Associação Espacial, na sigla em inglês), também conhecidos como Moran Local. ${ }^{41}$ Estes indicadores produzem valores específicos para cada área a partir da ocorrência dos fenômenos em estudo em áreas contíguas. (Cf. Câmara et al 2002, Simões 2005, Bichir 2006)

A partir dos valores do LISA considerados estatisticamente significantivos produz-se o chamado Moran Map. O Moran Map nos permite identificar aglomerados de áreas vizinhas (ou clusters espaciais) com altos índices de uma determinada variável (legenda alto-alto nos mapas apresentados a seguir); áreas com baixos índices vizinhas de outras áreas com baixos índices (baixo-baixo); áreas com altos índices vizinhas de áreas com baixos índices (alto-baixo); e áreas com baixos índices vizinhas de áreas com baixos índices (baixo-alto).

A seguir, analisamos os mapas do Moran Local para negros e brancos nas diferentes faixas de renda gerados no software TerraView 3.3.1.

Comparando os mapas do Moran Local das populações negra e branca do município de São Paulo (Mapas 4 e 5), notamos uma inversão quase que perfeita. Em geral, os clusters espaciais de alta concentração de uns correspondem aos clusters de baixa concentração dos outros. Os clusters de alta concentração dos brancos estão em áreas do quadrante sudoeste, na região de Santana (na parte leste da Zona Norte) e no início da Zona Leste. Estas áreas correspondem ao cluster de baixa concentração dos brancos. Os clusters de alta concentração dos negros - e baixa dos brancos - encontramse no extremo leste, na parte periférica da Zona Sul e em áreas dos extremos Norte e Oeste.

Os mapas Moran de negros e brancos com renda domiciliar até 5 saláriosmínimos (Mapas 6 e 7) são muito parecidos, evidenciando ainda mais a proximidade já constatada através das outras técnicas. Os clusters de alta concentração encontram-se nas mesmas regiões: extremos Sul, Leste e Noroeste. Entretanto, os clusters espaciais dos negros são menores do que os dos brancos. Pois os brancos desta faixa se espalham por mais áreas, enquanto que os negros estão mais concentrados.

\footnotetext{
${ }^{41}$ O Índice de Moran Local é dado para cada área i segundo a seguinte fórmula: $I_{i}=\frac{z_{i} \sum_{j=\mathbf{1}}^{n} w_{i j} z_{j}}{\sum_{j=\mathbf{1}}^{n} z_{j}^{\mathbf{z}}}$.
} 
Mapa 4: Moran Map dos Brancos

Moran Global I=0,785568

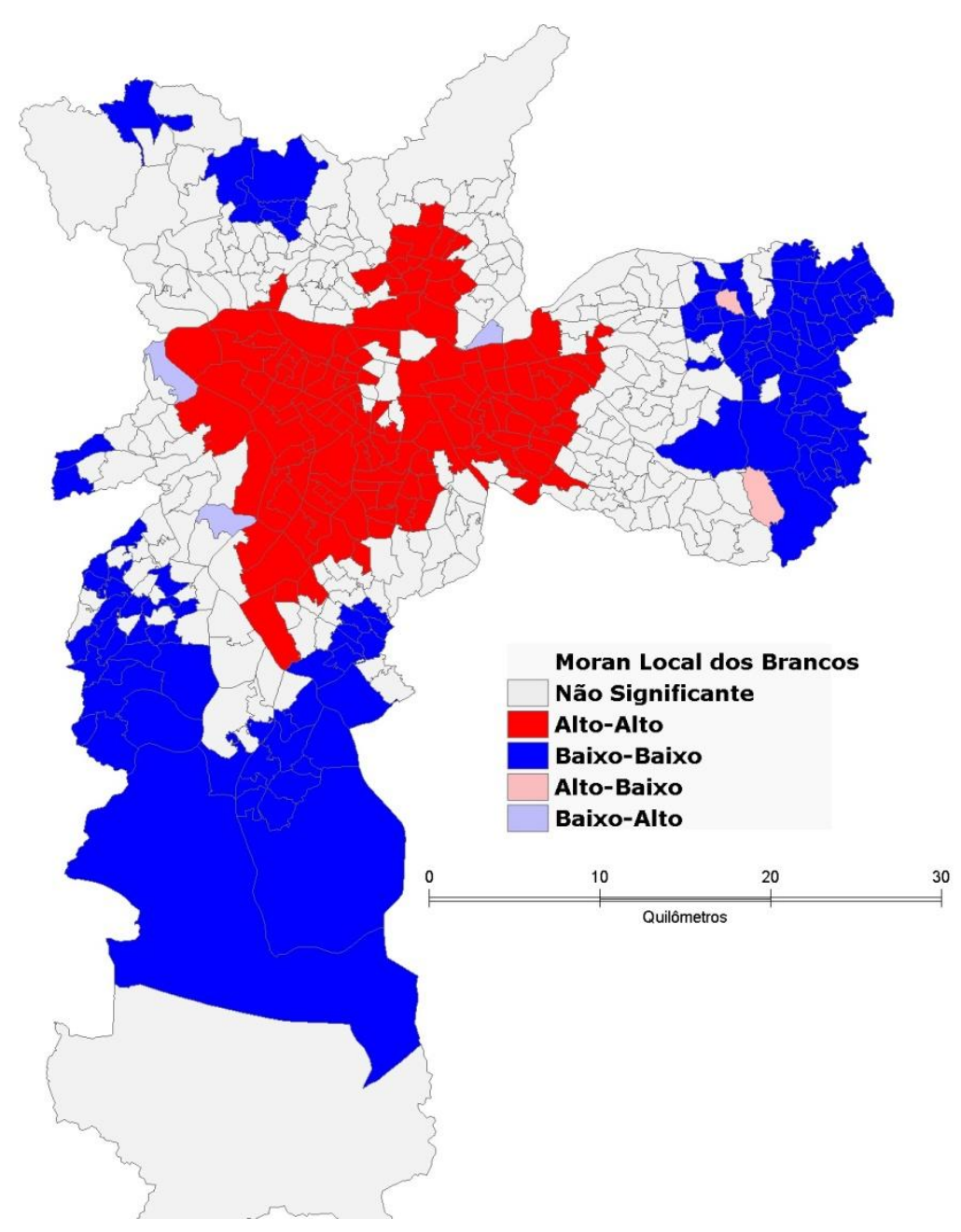

Mapa 5: Moran Map dos Negros

Moran Global I=0,785568

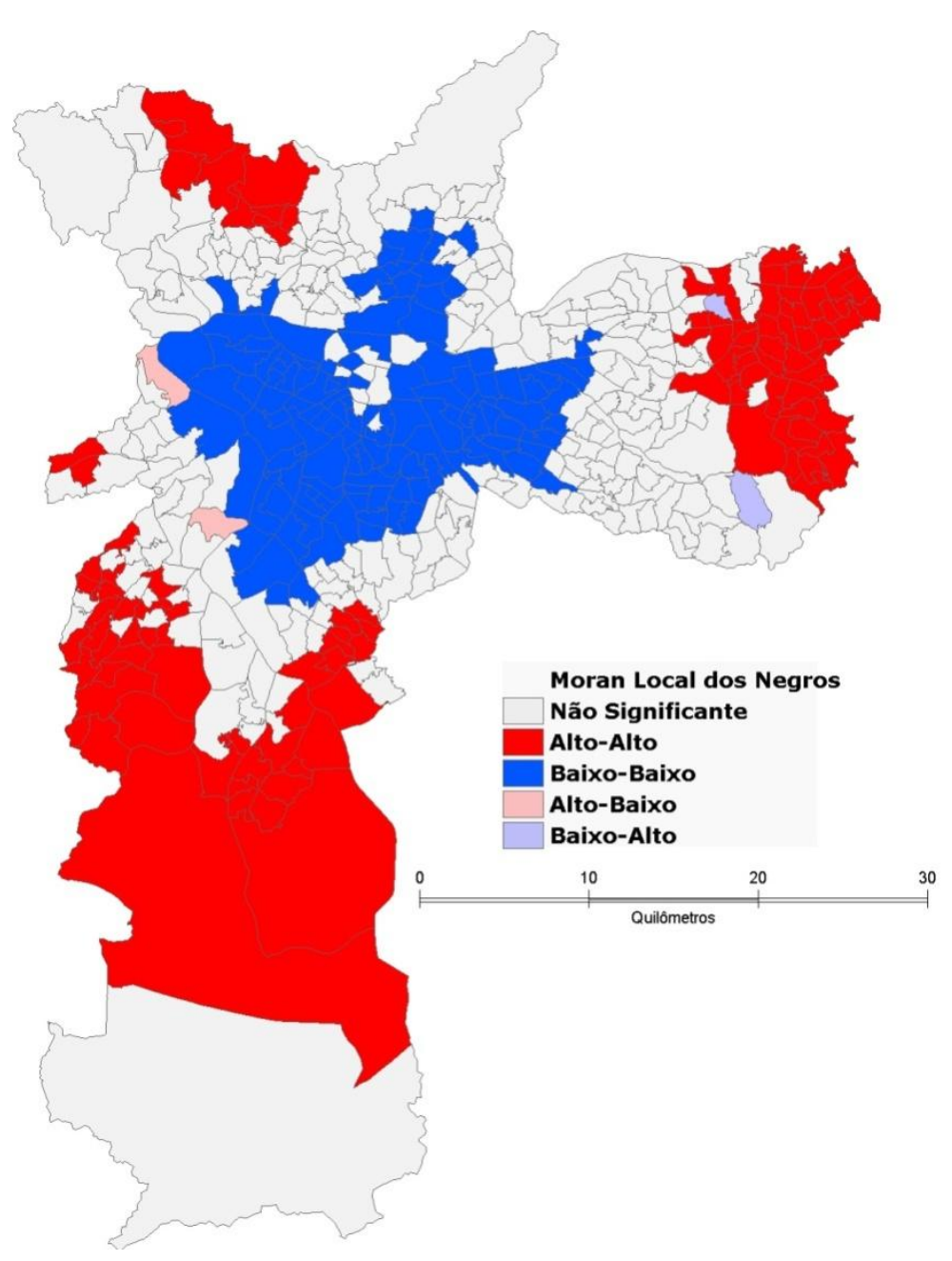


Mapa 6: Moran Map dos Brancos com renda domiciliar de até 5 salários mínimos

Moran Global I=0,753

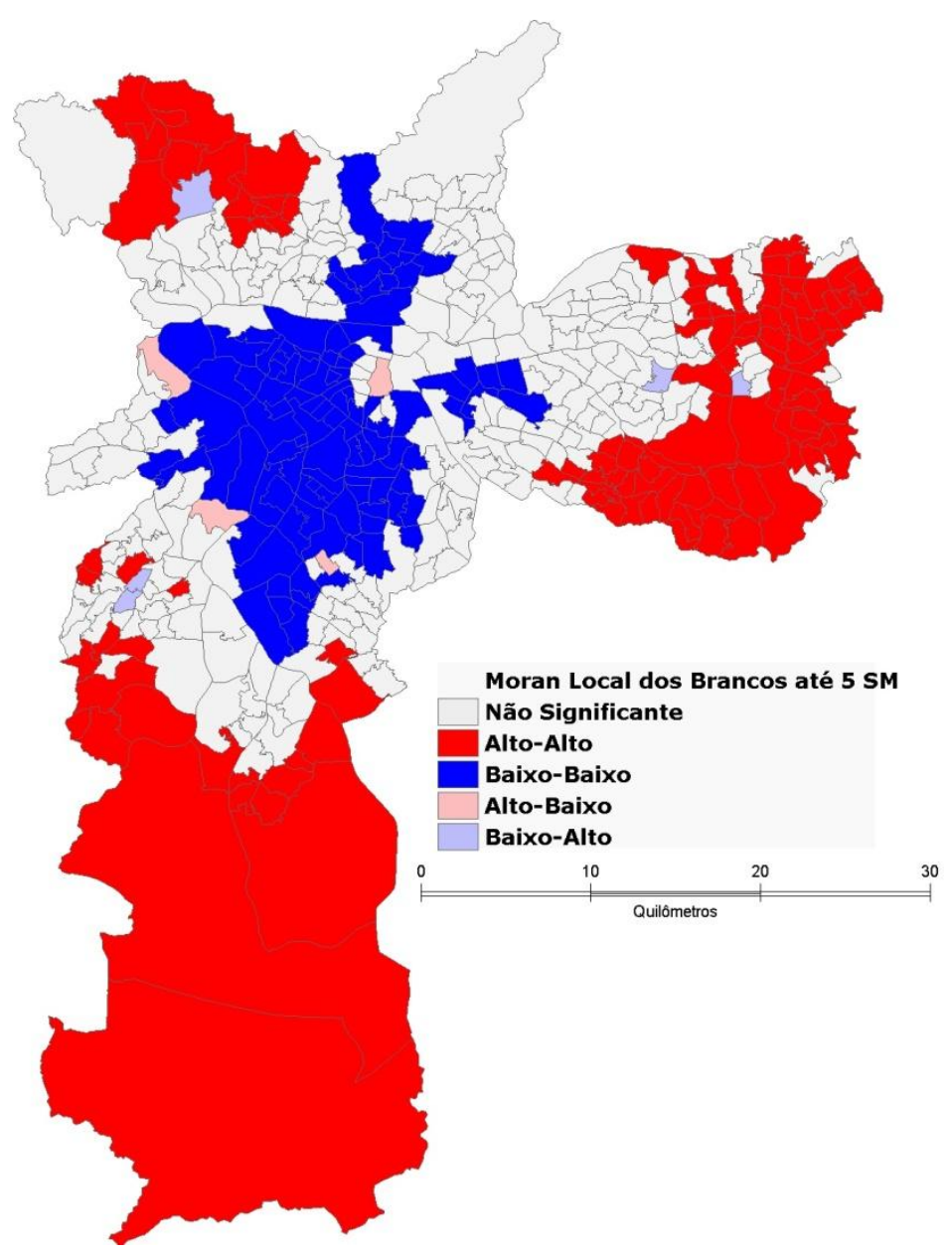

Mapa 7: Moran Map dos Negros com renda domiciliar de até 5 salários mínimos

Moran Global I= 0,744752

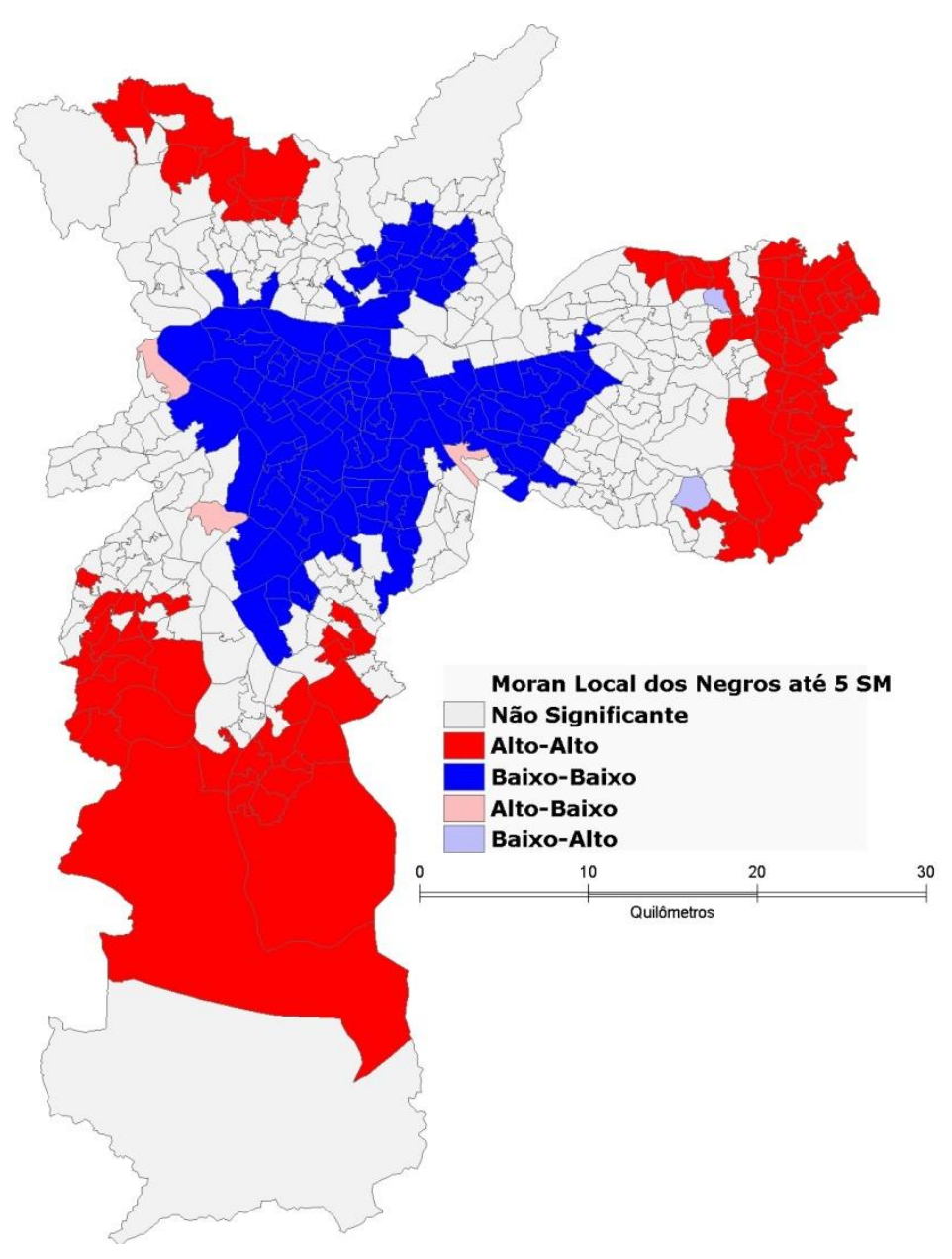


Mapa 8: Moran Map dos Brancos com renda domiciliar de 5 a 10 salários mínimos

Moran Global I=0,63242

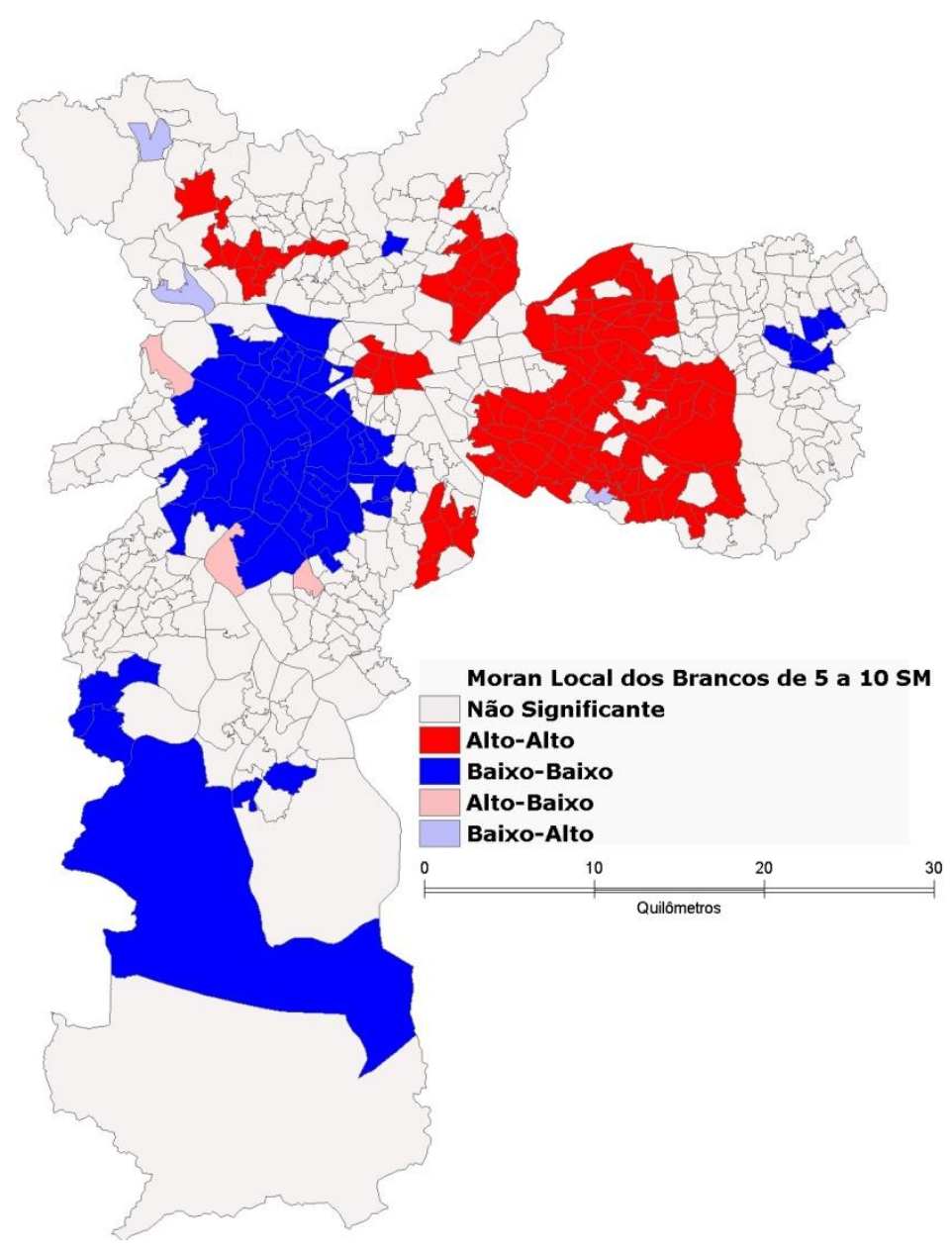

Mapa 9: Moran Map dos Negros com renda domiciliar de 5 a 10 salários mínimos

Moran Global I=0,738838

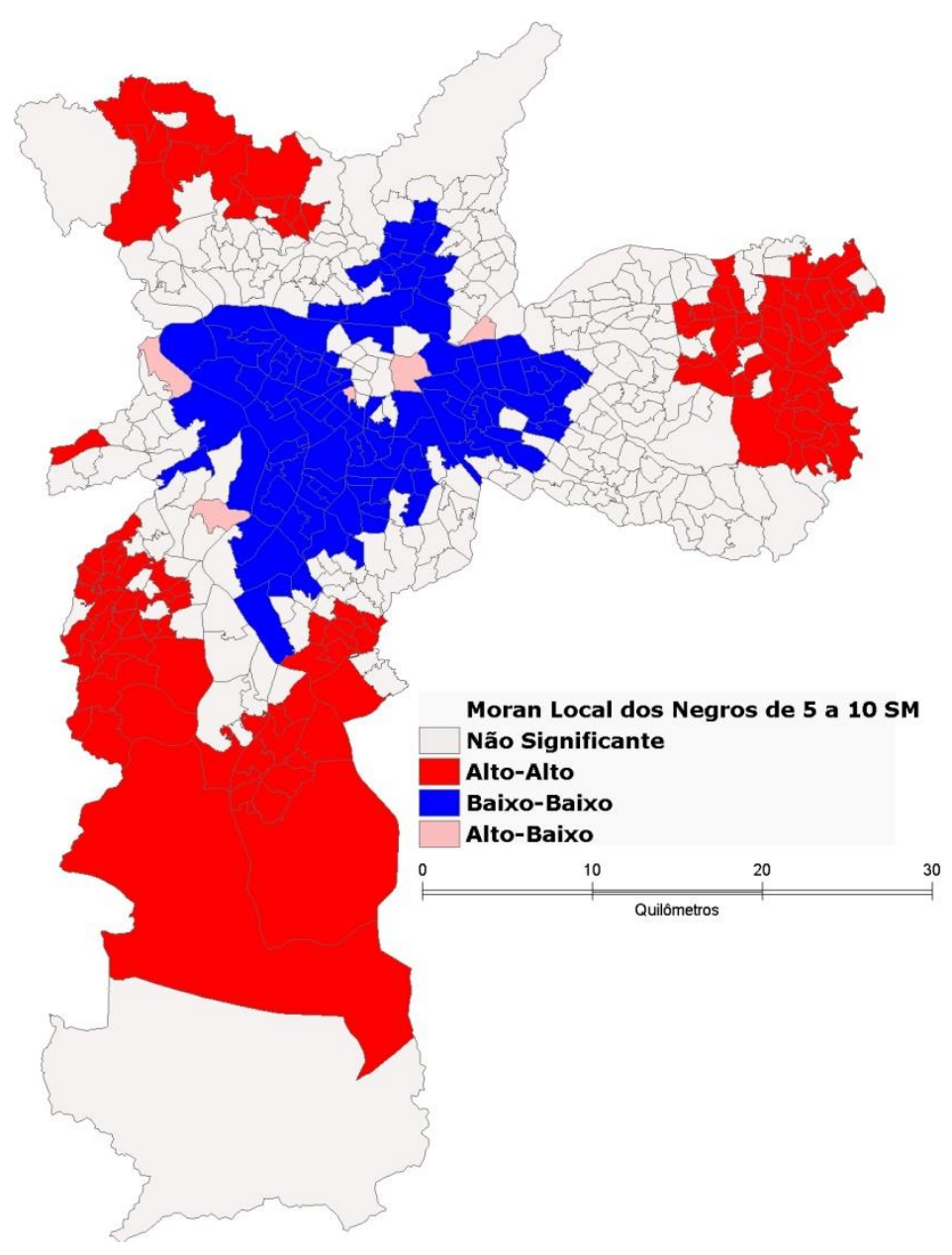


Mapa 10: Moran Map dos Brancos com renda domiciliar de 10 a 20 salários mínimos

Moran Global I=0,65188

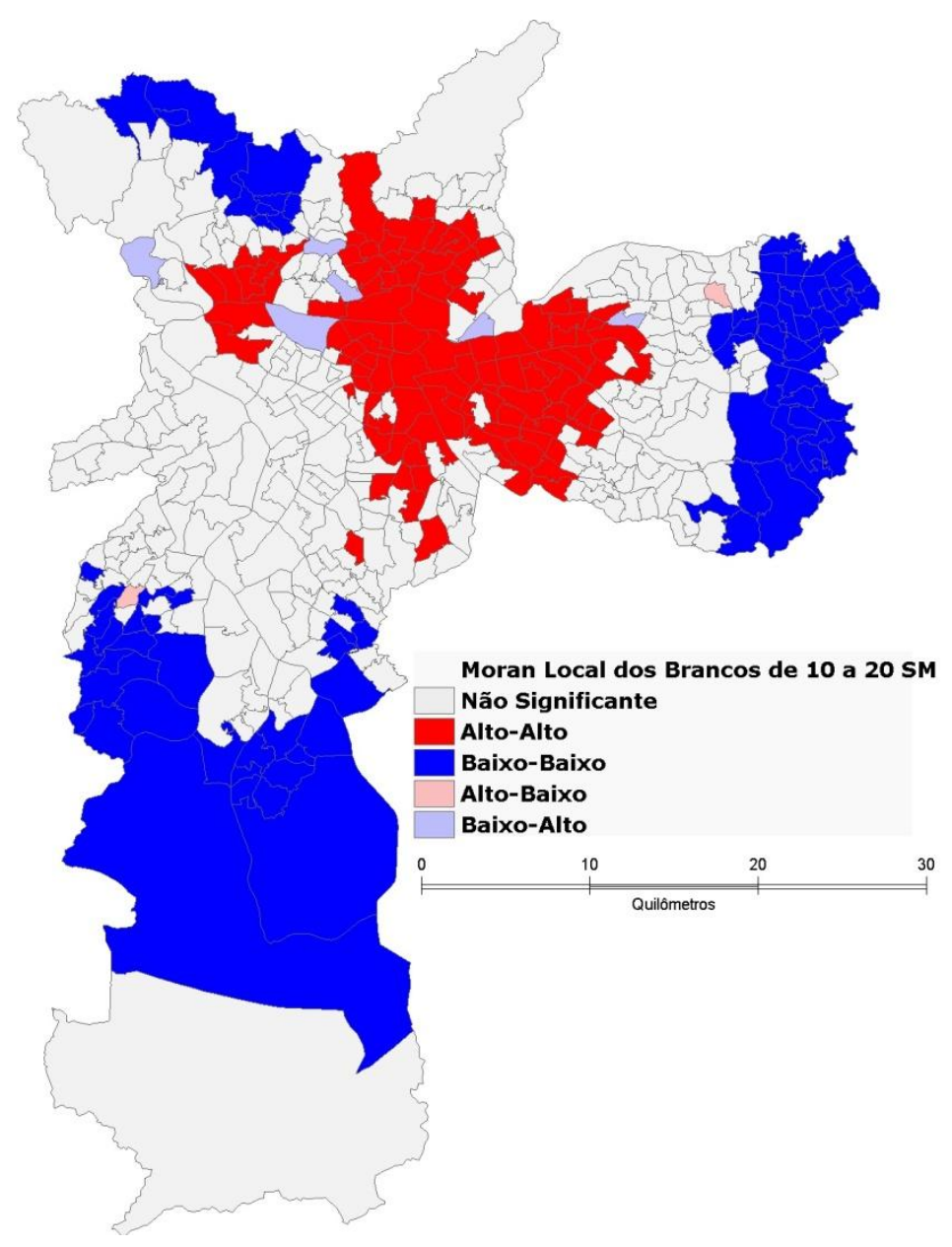

Mapa 11: Moran Map dos Negros com renda domiciliar de 10 a 20 salários mínimos

Moran Global I=0,575182

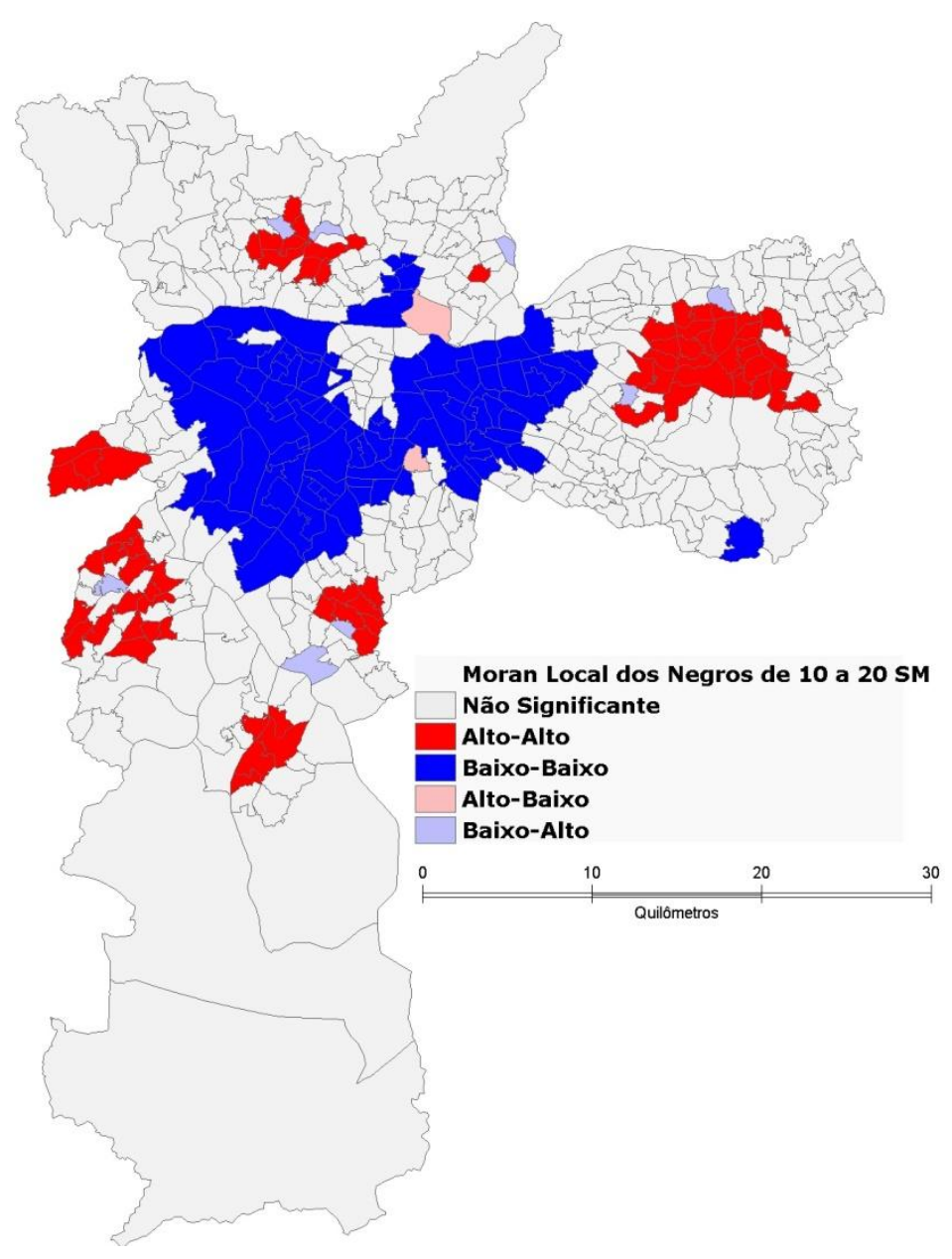


Mapa 12: Moran Map dos Brancos com renda domiciliar acima de 20 salários mínimos

Moran Global I=0,815496

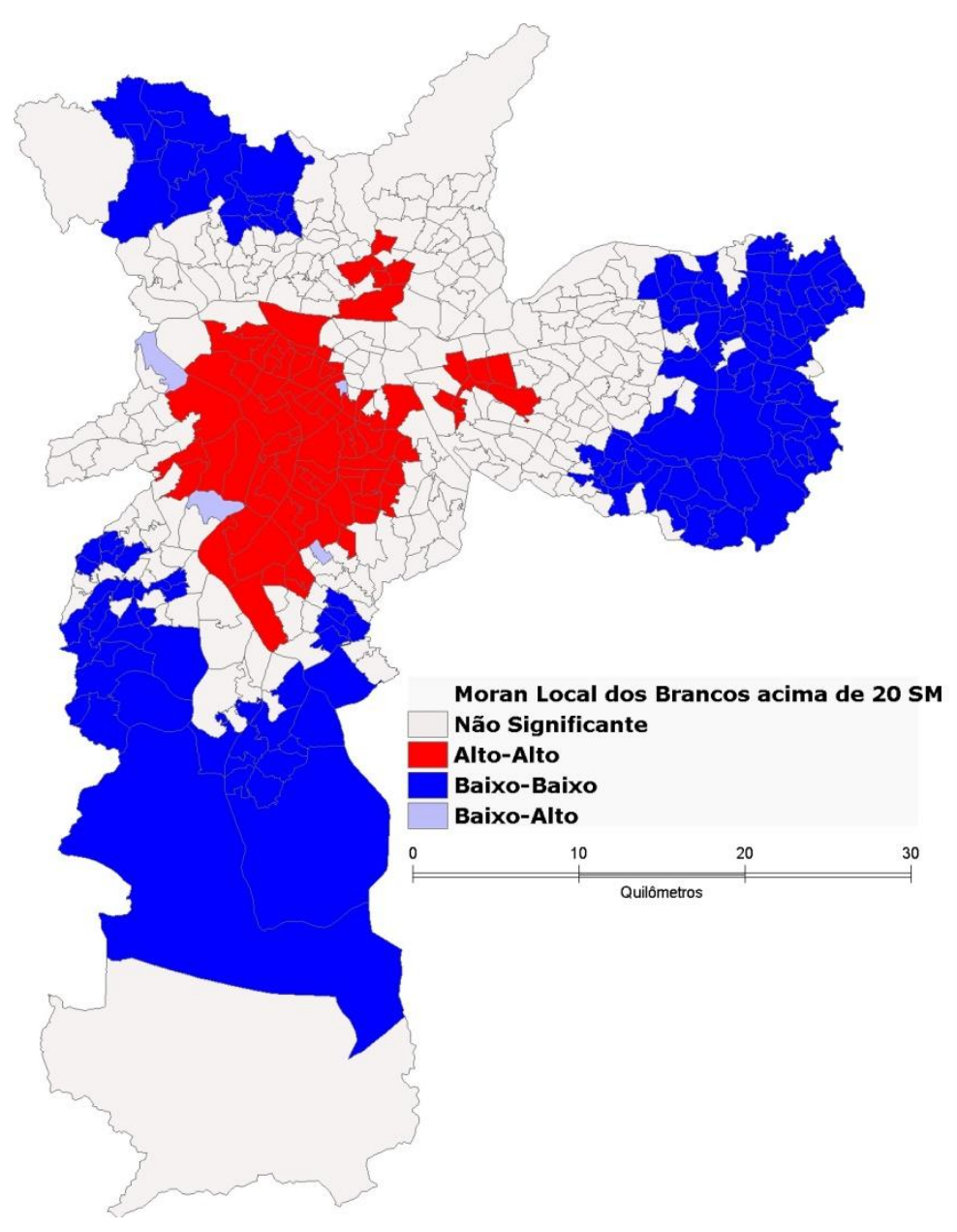

Mapa 13: Moran Map dos Negros com renda domiciliar acima de 20 salários mínimos

Moran Global I=0,396507

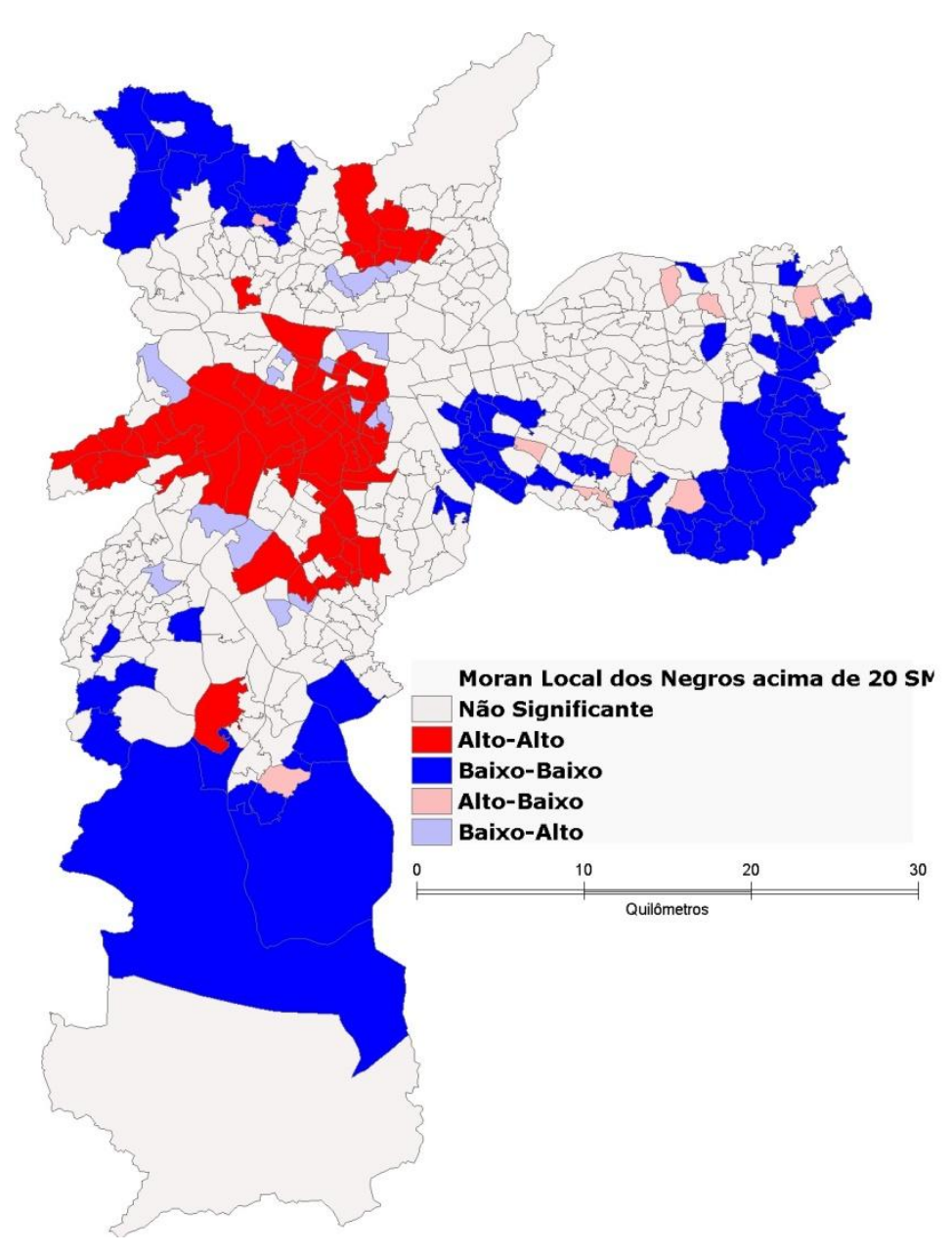


Na faixa de renda entre 5 e 10 salários-mínimos (Mapas 8 e 9) já notamos maiores diferenças na comparação entre negros e brancos. Os clusters espaciais dos brancos nesta faixa de renda localizam-se numa grande porção central da Zona Leste, na Zona Central da cidade e em áreas da Zona norte e no sudeste. Já os negros desta faixa concentram-se no extremo leste, no extremo noroeste e na grande parte periférica da Zona Sul. Algumas áreas de baixa autocorrelação espacial dos brancos deste estrato, na Zona Sul, fazem parte do cluster de alta concentração de negros desta faixa de renda.

Os brancos com renda domiciliar entre 10 e 20 salários-mínimos (Mapa 10) concentram-se num grande cluster espacial que se aproxima do formato de um L, indo da parte leste da Zona Norte até a parte inicial da Zona Leste. Também apresentam uma forte concentração em áreas dos distritos da Lapa, Pirituba e Freguesia do Ó. Os agrupamentos de baixa concentração deste grupo localizam-se nos extremos leste, noroeste, e na parte periférica da Zona Sul.

Podemos identificar diversos agrupamentos espaciais dos negros desta faixa de renda (Mapa 11): no miolo da Zona Leste (nas redondezas dos distritos de Arthur Alvim, Cidade Líder, Itaquera, Vila Jacuí e José Bonifácio); em áreas da Zona Norte (em torno da Brasilândia); no extremo Oeste (distrito de Raposo Tavares); e em três regiões da Zona Sul: na região dos distritos do Campo Limpo, Capão Redondo, Jardim Ângela e Jardim São Luís; na Região do Grajaú-Cidade Dutra; e na região do Jabaquara-Cidade Ademar. Os clusters de baixa concentração deste grupo compreendem grandes áreas do quadrante sudoeste e do início da Zona Leste.

Os mapas do Moran Local de negros e brancos com renda domiciliar superior à 20 salários-mínimos (Mapas 12 e 13), de modo geral, apresentam clusters espaciais de baixas concentração semelhantes: extremos leste, noroeste e na parte periférica da Zona Sul. O cluster de alta concentração dos brancos deste grupo abrange o entorno das áreas de elite do quadrante sudoeste, da região de Santana (na Zona Norte) e do início da Zona Leste. Os clusters de alta concentração dos negros deste estrato encontram-se numa faixa que vai da Zona Central da cidade até o extremo Oeste (em torno dos Jardins, Pinheiros, Butantã, Rio Pequeno até Raposo Tavares), com uma extensão até a região do Jabaquara (na Zona Sul), coincidindo com várias áreas que também fazem parte do agrupamento de maior concentração dos brancos deste estrato. Há ainda outro cluster de alta concentração na Zona Norte (Mandaqui e Tucuruvi). 
Convém observar que, nesta faixa de renda, observamos o maior valor do Moran Global $(0,81)$ para os brancos, e menor valor $(0,39)$, para os negros. Isto indica que os brancos deste estrato estão muito concentrados em áreas agrupadas, e que os negros estão mais dispersos.

\subsection{Considerações sobre os resultados}

Neste capítulo aplicamos diversas técnicas visando revelar os contornos da segregação residencial entre negros e brancos no município de São Paulo.

O índice de dissimilaridade, e também o Índice de Moran Global, são indicadores sintéticos de segregação, ou seja, resultam em um número que descreve o quanto os grupos estão segregados, isto é, o grau de segregação entre os grupos sociais delimitados, na área urbana em consideração. Os indicadores sintéticos têm como virtudes principais a facilidade de comunicação e o fato de permitirem comparações: seja entre cidades diferentes, com relação a séries históricas, ou entre diferentes subgrupos ou segmentos, como realizamos neste trabalho.

As comparações, de modo geral, requerem parâmetros que nos ajudem a definir o que significaria muito ou pouco segregado. Além disso, ao interpretar os indicadores precisamos estar atentos aos distintos contextos sociais nos quais se inserem os processos de segregação. Por isso, optamos por enfatizar comparações entre diferentes grupos sociais residentes na cidade de São Paulo, sem estendê-las a outras cidades.

Neste trabalho também testamos (muito provavelmente pela primeira vez) a aplicação dos locational attainment models para uma cidade brasileira. Esta técnica, ao permitir a inserção de vários controles nos modelos, favorece a formulação $e$ verificação de possíveis hipóteses explicativas para os processos de segregação, podendo se tornar uma ferramenta que trará grandes avanços para a descrição dos processos através dos quais determinadas características dos indivíduos podem ser convertidas em uma localização residencial mais favorável.

Entretanto, os problemas encontrados na aplicação que realizamos demonstram que, para a aplicação deste tipo de modelo, pelo menos para o caso brasileiro, ainda são necessários maior acúmulo de reflexões e uma maior quantidade de testes empíricos.

A análise tipológica, por se basear na classificação das áreas segundo critérios de interesse, nos permite conhecer em que tipo de área se registra as maiores e as menores 
concentrações dos grupos. Esta também foi a abordagem que recorremos ao analisar os quocientes locacionais segundo cada um dos dez grupos de áreas: obtivemos a comparação das oscilações das concentrações de negros e brancos em dez tipos de áreas, refinando as conclusões que obtivemos com a análise tipológica.

Por fim, com a análise dos mapas resultantes do Índice de Moran Local, conseguimos determinar onde se localizam as áreas de maior concentração de cada um dos grupos considerados. A seguir, retomamos os principais resultados encontrados com a aplicação das técnicas citadas.

Os dados analisados, de modo geral, corroboram a hipótese de que a segregação racial é baixa entre os mais pobres e vai aumentando conforme observamos estratos sociais mais altos. Esta tendência pode ser depreendida das duas tabelas em que apresentamos os resultados do índice de dissimilaridade, principalmente da Tabela 6 (na página 73), onde observamos o aumento da segregação entre negros e brancos com as faixas de renda.

Entretanto, a observação de que o mais alto índice de dissimilaridade ocorre na camada mais abastada parece ser desmentida pela análise das correlações entre os quocientes locacionais: no estrato mais alto, verificamos uma correlação positiva entre os quocientes locacionais. Além disso, a análise dos índices de Moran local mostra que nesta camada, diversas áreas de maior concentração residencial dos brancos também são áreas de alta concentração residencial dos negros.

Uma possível explicação é o problema técnico dos índices, já tratado neste capítulo: o índice de dissimilaridade tende a inflacionar quando o contingente numérico de um dos grupos é pequeno. E, como sabemos, são muito poucos os negros nesta faixa de renda (171.108 pessoas).

Todavia, não acreditamos que isto seja evidência de grande proximidade entre os negros e brancos do estrato social mais alto. O baixo valor do índice de Moran Global $(0,39$, o menor de todos) para os negros desta camada nos sugere que neste grupo ocorre um baixo grau de concentração em áreas contíguas. Em suma, podemos dizer que os negros do estrato social mais alto são poucos e bem dispersos pelo espaço da cidade.

Gostaríamos de traçar duas considerações a respeito da Tabela 7 (na página 74), que através dos valores do índice de dissimilaridade, designa o grau de distância residencial dos diversos segmentos com relação ao estrato social mais alto da cidade. 
Primeiramente, o fato do valor do índice para os negros da segunda faixa de renda mais alta (entre 10 e 20 salários-mínimos domiciliares) ser muito próximo do valor do índice para os brancos da faixa de renda mais baixa (até 5 salários-mínimos domiciliares). Os valores foram, respectivamente, 0,5233 e 0,5364. Isto significa que os negros da segunda camada mais alta estão quase tão próximos das pessoas mais ricas da cidade quanto os brancos mais pobres.

Não podemos atribuir este resultado do índice à pequena quantidade de negros nesta camada. Vimos que esta faixa de renda foi a que apresentou os maiores diferenciais entre negros e brancos em todas as medidas de segregação que aplicamos. Aliás, esta camada parece representar um verdadeiro ponto de inflexão: na camada mais baixa quase não notamos diferenças entre negros e brancos, na faixa entre 5 e 10 salários-mínimos surgem algumas diferenças de localização, mas nesta faixa entre 10 e 20 salários-mínimos, negros e brancos encontram-se mais distantes uns dos outros em termos residenciais.

O segundo aspecto que gostaríamos de destacar com relação ao resultado da tabela 7 relaciona-se a este primeiro: de modo geral, os brancos, seja lá qual for seu estrato social, estão muito mais próximos da camada mais alta do que quase todos os negros de condições semelhantes. Podemos dizer, em outras palavras, que os ricos, além de serem majoritariamente brancos, também estão cercados de brancos.

Esta assertiva também encontra apoio nos resultados das outras técnicas. A análise tipológica, por exemplo, evidenciou a sobre-representação dos brancos nas áreas de elite. Ao passo em que pudemos observar a sobre-representação de negros em áreas periféricas. Sobre-representação que vale, inclusive, para os negros de classe média.

Comparativamente, os brancos mais pobres também estão mais representados nas áreas de elite do que os negros. Nas áreas mais ricas a pobreza é mais branca. Isso pôde ser averiguado nos gráficos do quociente locacional que apontam que nas áreas mais ricas (7 a 10), há maior concentração de brancos pobres que de negros pobres.

Assim, se quanto mais baixa for a classe social a que pertencem, mais longe as pessoas se localizam da classe mais alta, os negros estão mais longe ainda. Inversamente, os negros, mesmo nas faixas de renda mais elevadas, tendem a estar mais concentrados em áreas periféricas, e distantes das áreas de residência dos estratos sociais mais altos. 
Em síntese, os dados apresentados demonstram que mesmo os negros nas faixas de renda mais alta têm maior concentração nas áreas mais pobres de São Paulo que os brancos nas mesmas faixas de renda. Além disso, nota-se uma tendência de residirem em áreas classificadas como periféricas. Sugerimos, assim, um maior grau de segregação racial nas faixas de renda mais altas, uma vez que os negros de alta renda têm maior concentração em áreas mais pobres e com mais negros. De igual maneira, pode-se depreender que as áreas de elite são espaços racialmente segregados, na medida em que concentram a população branca.

A seguir, na conclusão desta dissertação, comentaremos possíveis hipóteses explicativas para estes processos de segregação, e também exploraremos estes achados empíricos à luz dos escritos de alguns autores da sociologia das relações raciais no Brasil. 


\section{Considerações Finais}

Este trabalho teve como objetivo considerar a segregação residencial como uma dimensão relevante para a caracterização das relações raciais no Brasil, amparado na perspectiva sociológica de Edward Telles (2003). Nestes comentários finais retomaremos os resultados empíricos e os argumentos interpretativos presentes nesta dissertação e apresentaremos um conjunto de novas questões de pesquisa que emergem das reflexões realizados.

Telles (1993) havia ponderado que para a população de baixa renda, a possibilidade de escolher onde morar é muito reduzida, dadas as suas limitações materiais. De modo que "Se a segregação tiver que ocorrer num contexto onde não existem padrões residenciais previamente segregados, ou onde a segregação não tem respaldo legal, é mais provável que ocorra em faixas de renda onde são maiores as opções residenciais e onde a cor possa se tornar um critério na seleção do bairro" (p. 14). Ou seja, a maior liberdade para escolher onde morar e perto de que tipo de vizinhança seria dependente da renda, restando poucas oportunidades de escolha para a população mais pobre. Isso significa que as faixas de renda mais altas, nas quais os indivíduos já teriam superado as barreiras financeiras às suas possibilidades de escolher onde morar, seriam o contexto apropriado para verificarmos a possível ocorrência de segregação por raça.

Assim, este autor foi o primeiro a chamar atenção para o maior grau de segregação entre negros e brancos em estratos sociais mais altos, a partir da análise de dados do censo demográfico de 1980, para 35 áreas metropolitanas brasileiras.

Neste trabalho, ratificamos empiricamente a existência deste fato no município de São Paulo através de uma ampla análise quantitativa dos dados da Amostra do Censo de 2000, na qual foram empregadas variadas técnicas de mensuração. Utilizamos duas técnicas mais tradicionais, de aplicação comum: o índice de dissimilaridade e a análise tipológica; adaptamos uma medida dos estudos de economia regional para mensurar a segregação: o quociente locacional; recorremos a uma medida cuja aplicação tem crescido bastante nos estudos brasileiros mais recentes: o índice de Moran; e testamos uma nova técnica, aplicada nos Estados Unidos: os locational-attainment models [modelos de realização locacional]. Diversificando as técnicas pudemos verificar em 
que medida as tendências apontadas por cada uma poderiam ser reforçadas ou contrastadas pelas outras. Além do mais, isso acrescentou maior riqueza de detalhes na descrição da segregação em São Paulo.

Com relação à aplicação dos locational-attainment models aos dados do município de São Paulo, nosso experimento não foi muito bem sucedido, haja vista que os pressupostos estatísticos deste tipo de modelo de regressão não foram atendidos. Não temos certeza se isto se deve às particularidades do padrão brasileiro de segregação ou se são problemas da própria técnica. Nestas circunstâncias, acreditamos que isto enseja a realização de mais testes e possíveis adaptações destes modelos visando aplicações bem-sucedidas nos estudos brasileiros de segregação.

A partir dos resultados das técnicas de mensuração mencionadas, demonstramos que o grau de segregação entre negros e brancos, a princípio muito baixo na camada de menor renda, tende a aumentar conforme consideramos os padrões residenciais de negros e brancos nos estratos de maior renda. Destacamos que o maior grau de separação foi verificado na faixa de renda domiciliar entre 10 e 20 salários mínimos que pode ser considerada como referente à classe média.

Acrescenta-se a isto o fato de que, considerando-se as faixas de renda domiciliar mais altas, a concentração dos negros em áreas periféricas é bem maior que a dos brancos, ao passo que a proporção de brancos destes estratos em áreas de elite é bem maior que a dos negros.

Por fim, também demonstramos que os brancos, mesmo que de classes mais baixas, estão, comparativamente, mais representados em áreas mais ricas da cidade do que os negros. Não obstante os fatos de que as áreas periféricas podem ser consideradas espaços de grande mistura racial e de que registramos baixa segregação racial entre os mais pobres.

Um dos pressupostos adotados por este trabalho (presente nos modelos teóricos de Pierre Bourdieu, e também nos modelos norte-americanos da spatial assimilation e da place-stratification) é o de que a segregação residencial reflete as características da estratificação social, isto é, a distribuição residencial dos grupos no espaço urbano está relacionada à posição destes nas hierarquias sociais.

Já foram muito bem documentados pela produção sociológica brasileira os contornos de classe da segregação em nossas metrópoles. Entretanto, sem pretender 
invalidar estes primeiros, desejamos, com este trabalho, chamar atenção para o fator racial na determinação deste fenômeno, em especial nas classes médias e altas.

Desta forma, assim como a segregação era uma lente através da qual os norteamericanos avaliavam o quanto que os imigrantes e minorias étnico-raciais "progrediam" em sua sociedade, de forma análoga, podemos enxergar os graus de segregação entre negros e brancos nos estratos médios e altos de São Paulo como reveladores dos limites da inserção dos negros nestas camadas.

$\mathrm{Na}$ Introdução desta dissertação, mostramos que, para Telles, a sociedade brasileira poderia ser pensada segundo uma clivagem entre a classe média branca e a classe pobre multirracial. Isto porque "barreiras invisíveis" dificultariam a entrada dos negros nas classes médias e uma cultura racista propagaria representações de que os negros deveriam ocupar posições subalternas. Uma consequiência marcante destes mecanismos é o fato dos negros de renda mais alta não serem reconhecidos como "da classe média" e, com isso, serem alvo de constantes desconfianças e discriminações.

Neste sentido, merecem menção, também, as diferenças das pretensões e ambições entre negros e brancos, reveladas por Figueiredo (2000), interpretadas como efeito da incorporação das desigualdades raciais nas subjetividades dos indivíduos.

Estes argumentos se conectam com a interpretação fornecida por Antonio Sérgio Guimarães (2002), apresentada no Capítulo 1. Se, por um lado, as pesquisas empíricas e as interpretações sociológicas sobre as "classes analíticas" mostram a predominância de brancos nas classes sociais mais altas. Por outro, Guimarães nos mostra que a raça é um dado que informa as "representações nativas de classe". Isto significa que as representações correntes no senso comum em torno do que seria "a classe média", em geral, não contemplam a possibilidade de negros neste estrato, e daí o não reconhecimento e as discriminações sofridas pelos negros nestes contextos. Assim, a clivagem mencionada por Telles revela efeitos destas representações, explicitando a idéia de que as classes médias e altas seriam um "mundo dos brancos". 42

\footnotetext{
${ }^{42}$ A partir desta premissa das representações de classe nativas, é compreensível, também, a idéia corrente no senso comum de que, no Brasil, a segregação residencial seria definida unicamente, ou pelo menos preponderantemente, segundo linhas de classe. Considerando que as linhas de classe nativas são racialmente informadas, isto é, que as pessoas enxergam as características fenotípicas brancas como indicadoras de um estrato social mais alto e as negras como indicadoras de uma classe mais baixa, faz sentido o senso comum imaginar que a distância residencial entre negros e brancos ocorra unicamente porque estes são mais ricos e aqueles mais pobres.
} 
Voltemos, porém, às noções propostas por Telles. As "barreiras invisíveis" e a cultura racista podem ser identificadas na distância entre os grupos raciais cultivada nas relações horizontais dos estratos médios e altos, que mantêm os negros afastados.

Esta distância se expressa não apenas nos maiores índices de segregação racial que verificamos nestes estratos, mas também no fato dos brancos pobres estarem mais próximos das classes mais altas do que os negros pobres. Ou seja, não apenas estes estratos são compostos majoritariamente por brancos, como também, em geral, os pobres que os cercam também são brancos.

Além disso, o próprio fato dos negros de classe média residirem em espaços diferentes dos brancos deste mesmo estrato é um fator que pode contribuir para o seu não reconhecimento como classe média, uma vez que os negros não são vistos nos lugares onde se espera encontrar a classe média (branca). ${ }^{43}$

Convém, no entanto, que retomemos o raciocínio: as "barreiras invisíveis" à inserção dos negros nas classes médias e altas se expressariam na forma de discriminações e desconfianças enfrentadas por eles nestes estratos e da distância cultivada pelos indivíduos destas camadas; as representações nativas de classe fariam com que os negros não fossem reconhecidos como de classe média (e tampouco enxergassem a si próprios como tal); e assim, da mesma forma que a classe média não é um "lugar possível” para os negros, um bairro nobre também não o seria.

Entretanto, a relação entre premissas apresentadas e a existência de segregação racial nos estratos mais altos não é óbvia. Devendo haver, portanto, mecanismos mediadores que ocasionem esta segregação. Estes se relacionam às possíveis hipóteses explicativas para o fenômeno.

Portanto, exploraremos agora algumas destas hipóteses que podem ser levantadas para explicar as razões e mecanismo da separação residencial entre negros e brancos que constatamos nas camadas sociais mais altas. Nenhuma delas foi objeto de verificação por parte de pesquisas empíricas no Brasil. Sugerindo-nos, então, novas agendas de pesquisa.

\footnotetext{
${ }^{43}$ É interessante notar que em Racismo à Brasileira, Telles utiliza repetidas vezes a expressão "os poucos negros de classe média" para se referir a este grupo. Entretanto, no mesmo ano de publicação deste livro, em 2003, a tese de Ângela Figueiredo chama atenção para o crescimento numérico dos negros nestes estratos. Porém, se persistir esta distância dos negros de classe média com relação aos demais componentes desta camada social, podemos pensar que isto prejudicará a visibilidade e o reconhecimento destes negros como classe média. E, deste modo, o adjetivo poucos continuará sempre acompanhando este grupo, pois os negros destas classes continuarão a ser vistos como exceções.
} 
Nos Estados Unidos, os estudos sobre discriminação racial no mercado imobiliário é uma das linhas de pesquisa com mais força de explicação para os mecanismos de produção e manutenção da segregação residencial. As pesquisas têm revelado que, além dos negros enfrentarem maiores dificuldades do que os brancos para obter empréstimos e aprovações de financiamento de imóveis, constata-se tratamento diferenciado por parte dos corretores, que chegam até mesmo a direcionar clientes de distintos grupos étnicos-raciais para áreas diferentes. Neste campo de pesquisas, aplicase uma técnica conhecida como audit-studies, que, em suma, consiste no seguinte: pesquisadores negros e brancos simulam a procurar imóveis e comparam as diferenças de tratamento recebidas (Cf. Charles 2003).

Existe um histórico de mercados imobiliários duplos e de discriminações sistemáticas nas questões de moradia que justificam a força deste campo de pesquisas nos Estados Unidos. Ao passo que, a princípio, não temos evidência de discriminação sistemática no mercado imobiliário brasileiro. Entretanto, nunca foi realizada nenhuma pesquisa que avaliasse a existência ou não deste fato no Brasil.

Este tipo de mecanismo de segregação, ocasionado por fatores externos ao arbítrio dos indivíduos, como discriminação racial no mercado imobiliário ou legislação segregacionista, por exemplo, são chamados pela literatura de segregação involuntária.

Por outro lado, existe também a chamada segregação voluntária. O que definiria esta forma de segregação é o fato de que ela se constitui a partir das opções individuais. Neste caso, a questão sociológica que devemos fazer é: existiriam motivações coletivas por traz destas opções individuais?

Convém, todavia, fazer a ressalva de que no caso da segregação que observamos entre negros e brancos nas classes médias e altas ser voluntária, isso não necessariamente significa que ela seja motivada por uma repulsa racial consciente. Também é possível que a segregação voluntária seja motivada, por exemplo, pelo fato dos negros e brancos terem preferências residenciais distintas, ou seja, cada grupo racial almejaria viver em bairros diferentes. Possibilidade que, se comprovada, seria muito significativa para as questões que discutimos.

Deste modo, devemos considerar, também, a possibilidade da segregação ser voluntária, ou seja, que há, por parte da classe média negra, uma opção ou uma preferência por morar em áreas que classificamos como intermediárias e periféricas em vez de residir nos espaços tradicionais da elite. 
Para Telles (1995), estas opções por parte dos negros podem ser motivadas por medo de tornarem-se alvo de discriminações em outros bairros, ou por uma questão de etnicidade. Com relação a este último fator, o autor acredita que, tendo em vista que se observa um crescimento da afirmação da identidade étnica entre os negros brasileiros, é possível que vínculos culturais ou a proximidade com determinadas "organizações negras" - como organizações culturais, escolas de samba, terreiros de candomblé, organizações do movimento negro etc. - seja um fator determinante das escolhas residenciais deste grupo.

No entanto, sem invalidar estas hipóteses de Telles, gostaríamos de remeter a um fato, talvez, mais disseminado, ao qual Agier (1990) chamou de "identidade quaseétnica”. Com esta expressão, Michel Agier se refere a uma identificação com práticas e modos de vida específicos de determinados locais e da inserção em redes de sociabilidade e "quase-familiaridade" de certos bairros. Esta identificação seria, antes de tudo, propriamente local.

Porém, se fôssemos instados a dizer se este tipo de identificação local por parte dos negros poderia ser mais de classe ou mais racial, diríamos que é mais provável que ela seja de "classe nativa".

Isso porque, considerando a ideia "interiorização das desigualdades raciais no plano das subjetividades", proposta por Figueiredo (2000), poderíamos especular que se os negros têm aspirações de renda e ocupação inferiores às dos brancos, isto também poderia valer para o campo habitacional. E, deste modo, por mais que tivessem rendas semelhantes, as preferências residenciais dos brancos elegeriam bairros mais valorizados (simbólica e materialmente) do que as dos negros. Isto seria indicativo de que negros e brancos de classe média teriam, não apenas distintos parâmetros para avaliar seus possíveis locais de moradia, mas também distintos habitus de classe. ${ }^{44}$

Assim, a hipótese da segregação voluntária por parte dos negros de classe média teria um contraponto da parte dos brancos. Ou seja, cada grupo teria preferências por bairros diferentes, evitando, também, diferentes bairros. Caberia, portanto, investigar, primeiro, se de fato estes grupos exibem diferentes sistemas de preferência residencial e, em segundo lugar, quais parâmetros pautariam cada um destes sistemas.

\footnotetext{
${ }^{44}$ No capítulo 1 apresentamos o trabalho de Soares (2004), que argumentava que os negros de classe média tinham um habitus intermediário entre a classe média e as classes populares.
} 
Existem, porém, outros mecanismos que podem ser causadores dos padrões residenciais observados nesta pesquisa que, caso fossem mensurados e comprovados, poderiam levar a alterações de nossas conclusões.

Por exemplo, ao comparar os negros e brancos de classes médias e altas, não dispúnhamos de informações que nos permitissem controlar o tempo de ascensão destas pessoas. É provável que indivíduos e famílias de ascensão social recente não tenham uma segurança financeira e uma estabilidade de posição de classe suficiente para a aquisição de imóveis nos bairros mais valorizados da cidade. Assim, se as desvantagens de localização dos negros fossem atribuídas ao pouco tempo de ascensão social, verificaríamos que os negros que estivessem nas camadas médias e altas a mais gerações morariam mais próximos dos brancos.

A apuração empírica desta hipótese poderia: no caso de sua conformação, diminuir a importância da raça para a segregação residencial, prejudicando nossas conclusões; ou no caso de sua refutação, reforçar nossas conclusões sobre a importância da raça. Além do mais, a inclusão da variável tempo de ascensão seria muito pertinente para refletirmos a respeito das possíveis diferenças nas preferências residenciais.

Entretanto, o banco de dados da Amostra do Censo, no qual se baseiam as pesquisas sobre segregação, não nos fornece informações que nos permitam apurar ascensão social individual. Caso estivessem disponíveis, com estas informações poderíamos avaliar, a partir de dados individuais, os mecanismos pelos quais os movimentos dos indivíduos nas hierarquias de estratificação social se refletiriam em movimentos no espaço urbano.

Mas algo que pode ser avaliado através das informações disponíveis na Amostra do Censo é o impacto de grandes movimentos de mobilidade social na segregação residencial. É sabido que um fato marcante desta primeira década do século XXI foi a forte mobilidade social na população brasileira. Em que medida isto se refletiria nos padrões de segregação? Estas tendências podem ser desvendadas através da comparação entre as alterações da estratificação social de 2000 para 2010, e as alterações da segregação residencial neste período.

Outro fator importante não mensurado por esta pesquisa, e também ligado à questão que há quantas gerações se ocupa uma determinada posição na estratificação social é a questão da herança. Neste sentido, é possível que uma parcela da população estudada resida em determinadas áreas pelo fato de terem herdado o imóvel onde 
moram. Porém, também não foi possível apurar informações a respeito de imóveis herdados.

Por fim, um último fator cujo efeito sobre os dados de segregação não foi mensurado é o fato de que o crescimento da cidade não ocorre mais nas áreas tradicionais da elite próximas à região central da cidade. Torres (2005b) mostra que muitas áreas centrais, da chamada "cidade consolidada", têm crescimento demográfico negativo, ou seja, estão em esvaziamento. Além disso, Marques (2005b) assinala que alguns segmentos de alta renda estão se mudando para novos bairros nobres, mais afastados ou nas bordas do tradicional quadrante sudoeste. ${ }^{45}$

Autores como Villaça (2004) e Torres (2004b) têm alertado para a importância de estudarmos a segregação residencial tendo em vista o fato de que ela se insere dentro de processos mais amplos. Pensar a segregação como parte de um processo implica que consideremos, além das suas causas, também as suas conseqüências, como faremos agora.

Haja vista que o espaço não apenas reflete a estratificação, mas também opera como um mecanismo de reprodução, estratificando as pessoas, é possível que a o fato de morar em áreas de menor prestígio residencial seja mais uma desvantagem que os negros acumulariam nas disputas pela realização sócio-econômica.

Sem embargo, apesar da maioria dos autores ressaltarem os efeitos negativos de se residir em bairros com alta concentração de pobreza - como as periferias -, Bichir (2006) ressalva que "destacar as conseqüências da segregação não implica considerá-la um problema em si, mas sim um fenômeno que pode ter efeitos negativos e positivos [podendo] inclusive se alterar ao longo do tempo" (p. 18).

Reúno, agora, as diversas possíveis conseqüências da segregação citadas pela literatura (Cf. Torres 2004a; Bichir 2006; Carvalho e Barreto 2007; Qadeer 2004; Telles 1993, 1995; Sabatini et al. 2004; Flores 2006) em quatro grupos descritos abaixo.

Em primeiro lugar, problemas de inserção no mercado de trabalho, acesso à cidade e às políticas públicas de qualidade. Nas regiões periféricas os serviços públicos oferecidos costumam ser de pior qualidade. Destaco aqui, os problemas com o transporte urbano, visto que os empregos geralmente localizam-se em regiões distantes da cidade, onde residem as classes de renda mais alta. Segundo Torres (2004a) "a

\footnotetext{
${ }^{45}$ Conformando as áreas que foram classificadas no grupo 10 por Marques (2005b), tal como vimos no capítulo 3.
} 
moradia em periferias distantes e em cidades-dormitórios além de aumentar os custos de transporte - com impactos para a renda disponível e conforto dos moradores - trás também efeitos sobre o acesso à informação sobre postos de trabalho, bem como eleva substancialmente os custos de procurar emprego.”(p. 44). A inserção no mercado de trabalho é ainda prejudicada por estigmas que pesam sobre os moradores das periferias e pelo isolamento de redes sociais que podem proporcionar esta inserção e, também, maiores possibilidades de ascensão social. Carvalho e Barreto (2007) consideram que "a rede de relações sociais constitui um fator decisivo para ter acesso ao mercado de trabalho, quem mora em um lugar onde só tem gente precariamente ocupada ou desempregada termina tendo restritas as suas oportunidades ocupacionais." (p. 269). Assim, os fatores aqui apontados exercem forte influência no posicionamento dos indivíduos no mercado de trabalho, dificultando, inclusive, movimentos de ascensão social.

Com relação aos negros de classe média, podemos nos perguntar em que medida o espaço onde residem dificulta ou não a reprodução de sua posição de classe. Outra questão que surge aponta para as redes de relações sociais deste grupo. Seriam redes mais ou menos restritas ao seu espaço de residência? Se menos restritas, em que medida elas podem compensar os problemas de se residir em um espaço segregado? Além disso, caberia a reconstituição dos trajetos dos membros deste grupo nos espaços da cidade e o acesso deles aos equipamentos urbanos.

Em segundo lugar, a concentração de determinados problemas e a sobreposição de certas carências nas áreas de pobreza segregada fazem da população lá residente a mais provável de ser atingida por problemas como fracasso escolar, desemprego, gravidez na adolescência, violência e atividade criminal - tratam-se dos chamados “efeitos de vizinhança” (Cf. Torres 2004a).

Esses dois conjuntos de conseqüências citados nos levam a um terceiro tipo, que resulta deles. A pertença a esses territórios não só pode facilitar estigmas e estereótipos que tornam os indivíduos que neles residem alvos prováveis de preconceitos e violências, como também causa um sentimento de exclusão e desesperança, “(...) além de conseqüências nocivas do ponto de vista da socialização, da transmissão de valores e modelos, contribuindo para a reprodução da pobreza" (Bichir 2006). Isto pode implicar, inclusive, no que Figueiredo (2000) chamou de "interiorização das desigualdades", ou 
seja, o fato das desigualdades gerarem representações que atuam como limitadoras das aspirações de indivíduos membros do grupo estigmatizado (Cf. também Jesus 2008).

Por último, morar em espaços mais homogêneos pode também servir de base para a geração de laços de solidariedade e afirmação de identidades. Redes sociais locais e relações de vizinhança ajudam a promover o apoio mútuo e o associativismo, aumentando a capacidade de organização para a constituição de instituições comunitárias e de recreação, para a negociação de melhores serviços públicos com o Estado e para a consolidação de identidades. O trabalho de Oliveira (1996), citado no capítulo 2, discute como identidades raciais podem ser fomentadas por movimentos locais que lutam por melhorias de infra-estrutura urbana. Telles (1996), considerando o fato de a segregação norte-americana ter contribuído para a organização dos negros daquele país, acredita que a segregação moderada influi no baixo nível de consciência racial e de organização da população negra no Brasil. Entretanto, esta é outra hipótese para a qual não há nenhuma evidência.

Para encerrar, acreditamos que, nesta dissertação, foi possível levantar evidências da segregação racial nos estratos sociais mais altos da cidade de São Paulo. Estes resultados, obtidos a partir dos dados do censo demográfico de 2000, poderão servir como referência tanto para um acompanhamento diacrônico das transformações de tendências residenciais nesta cidade, informando séries temporais; como para comparações entre padrões de segregação em diferentes cidades brasileiras. Além disso, as reflexões e as questões levantadas neste trabalho podem sugerir novas perspectivas e possibilidades de pesquisa a serem exploradas na sociologia das relações raciais e nos estudos sobre segregação residencial nas metrópoles brasileiras. 


\section{Referências Bibliográficas}

AGIER, Michel. "Espaço Urbano, Família e Status Social: O novo operariado baiano nos seus bairros" Cadernos CRH Vol. 3 No. 13. 1990.

ALBA, Richard; LOGAN, John. "Variations on Two Themes: Racial and Ethnic Patterns in the Attainment of Suburban Residence". Demography, Vol. 28, No. 3 Aug., 1991

ALBA, Richard; LOGAN, John. "Analyzing locational attainments: constructing individual-level regression models using aggregate data". Sociological Methods and Research. 20:367-97. 1992.

ALBA, Richard; LOGAN, John. "Minority proximity to whites in suburbs: an individual-level analysis of segregation". American Journal of Sociology. 98(6):1388427. 1993.

ALBA, Richard; LOGAN, John; STULTS B. "How segregated are middle-class African Americans?" Social Problems. 47(4):543-58. 2000.

ANSELIN, Luc. "Local indicator of spatial association - LISA". Geografical Analysis, 27, pp. 91-115. 1995.

ÁVILA, Milene Peixoto Ávila. Periferia é periferia em qualquer lugar? Antenor Garcia: estudo de uma periferia interiorana. Dissertação de Mestrado. São Carlos. UFSCar. 2006.

AZEVEDO, Thales de. "Classes Sociais e Grupos de Prestígio". In: Cultura e situação racial no Brasil. Rio de Janeiro: Civilização Brasileira. (1966 [1956]).

AZEVEDO, Thales de. As elites de cor, um estudo de ascensão social. EdUFBA: Salvador. (1996 [1953]). 
BASTIDE, Roger; FERNANDES, Florestan. Brancos e Negros em São Paulo. São Paulo. Companhia Editora Nacional. 1959.

BICHIR, Renata Mirandola. Segregação e Acesso a Políticas Públicas no Município de São Paulo. Dissertação de Mestrado em Ciência Política. São Paulo: Faculdade de Filosofia, Letras e Ciências Humanas (USP). 2006.

BOURDIEU, Pierre. O Poder Simbólico. Rio de Janeiro: Bertand Brasil. 1989.

BOURDIEU, Pierre. "Efeitos de Lugar”. In: A Miséria do Mundo. Petrópolis: Vozes. 1997.

BOURDIEU, Pierre. "Condição de Classe e Posição de Classe”. In: A economia das trocas simbólicas. São Paulo: Editora Perspectiva. 2005.

CALDEIRA, Teresa. Cidade de muros: crime, segregação e cidadania em São Paulo. São Paulo, Edusp/Ed. 34. 2000.

CÂMARA, Gilberto; CARVALHO, Marília Sá; CRUZ, Oswaldo Gonçalves; CORREA, Virgínia. “Análise Espacial de Áreas”. In: Análise Espacial de Dados Geográficos. Disponível em <www.dpi.inpe.br/gilberto/livro/analise>. 2002.

CARDOSO, Fernando Henrique; IANNI, Octávio. Cor e Mobilidade Social em Florianópolis: Aspectos das Relações entre Negros e Brancos numa Comunidade do Brasil Meridional. São Paulo, Companhia Editora Nacional (Coleção Brasiliana, vol. 307). 1960.

CARRIL, Lourdes de Fátima Bezerra. Quilombo, favela e periferia: a longa busca da cidadania. Tese de Doutorado em Geografia Humana. São Paulo: FFLCH-USP. 2003.

CARVALHO, Inaiá; BARRETO, Vanda Sá "Segregação residencial, condição social e raça em Salvador" Cadernos Metrópole 18, 2º sem 2007. 
CHARLES, Camille Zubrinsky. "The Dynamics of Racial Residential Segregation.” Annual Review of Sociology, Vol. 29. 2003.

CORTESE, Charles F.; FALK, R. Frank; COHEN, Jack K. "Further Considerations on the Methodological Analysis of Segregation Indices." American Sociological Review 41:630-37. 1976.

COSTA, Carolina Souza Ribeiro da; RIBEIRO, Luiz Cesar de Queiroz. "Cor, Status e Segregação Residencial em Belo Horizonte: Notas Exploratórias”. In: XI Seminário sobra a Economia Mineira. Diamantina: CEDEPLAR/UFMG. 2004.

DUNCAN, Otis Dudley; DUNCAN. Beverly. "A Methodological Analysis of Segregation Indexes." American Sociological Review 20:210-17. 1955.

FERNANDES, Florestan. A integração do negro na sociedade de classes. São Paulo: Editora Ática. 1978.

FIGUEIREDO, Ângela. "Efeitos e interiorização das diferenças: representação subjetiva da classe entre famílias negras e brancas". Interseções - Revista de Estudos Interdisciplinares da UERJ. Rio de Janeiro. Ano 2, n. 1. 2000.

FIGUEIREDO, Ângela. Novas Elites de Cor: Estudo sobre os Profissionais Liberais Negros de Salvador. São Paulo: Annablume. 2002.

FIGUEIREDO, Angela, A Classe média negra não vai ao paraíso: trajetórias, perfis e negritude entre os empresários negros. Tese de doutorado em Sociologia, IUPERJ. Rio de Janeiro, 2003.

FIGUEIREDO, Angela. "Fora do jogo: a experiência dos negros na classe média brasileira”. Cadernos Pagu, no.23. 2004. 
FLORES, Carolina. "Consequências da Segregação Residencial: teoria e métodos”. In: CUNHA, José Marcos Pinto da (org.). Novas metrópoles paulistas: população, vulnerabilidade e segregação. Campinas, SP : UNICAMP/NEPO, 2006.

FRUGOLI Jr. Heitor. "O urbano em questão na antropologia: interfaces com a sociologia”. Revista de Antropologia Vol. 48. №. 1. São Paulo: USP. 2005

GARCIA, Antônia. Desigualdades Raciais e Segregação Urbana em Antigas Capitais: Salvador, Cidade d'Oxum e Rio de Janeiro. Tese de Doutorado em Planejamento Urbano e Regional. Rio de Janeiro: IPPUR-UFRJ. 2006.

GUASCO, Pedro Paulo. Num país chamado Periferia: identidade e representação da realidade entre os rappers de São Paulo. Dissertação de Mestrado em Antropologia Social. São Paulo: FFLCH-USP. 2000.

GUIMARÃES, Antonio Sérgio. Classes, Raças e Democracia. São Paulo, Editora 34. 2002.

GUIMARÃES, Antonio Sérgio Alfredo. "Como trabalhar com "raça" em sociologia". Educação e Pesquisa, vol.29. 2003.

GUIMARÃES, Antonio Sérgio Alfredo. "Preconceito de cor e racismo no Brasil". Revista de Antropologia 47. 2004.

GUIMARÃES, Antonio Sérgio. Racismo e Anti-Racismo no Brasil. São Paulo, Editora 34. 2005.

HASENBALG, C. Discriminação e desigualdades raciais no Brasil. Belo Horizonte: Editora UFMG, Rio de Janeiro: Iuperj. 2005.

ICELAND, John; WILKES, Rima. "Does Socioeconomic Status Matter? Race, Class, and Residential Segregation”. Social Problems, Vol. 53, No. 2, May, 2006. 
JESUS, Rodrigo Ednilson de. "O que ser aos trinta? Aspirações ocupacionais de jovens negros e brancos na cidade de Belo Horizonte". In: V COPENE Congresso Brasileiro de Pesquisadores Negros. 2008.

LIMA, Márcia. Serviço de "branco" e serviço de "preto". Um estudo sobre "cor" e trabalho no Brasil urbano. Tese de Doutorado em Sociologia e Antropologia, UFRJ. Rio de Janeiro, 2001.

LOGAN, John. "Growth, Politics, and the Stratification of Places". The American Journal of Sociology, Vol. 84, No. 2. Sep., 1978

LOGAN, John; ALBA, Richard; LEUNG, Shu Yin. "Minority Access to White Suburbs: A Multiregional Comparison”. Social Forces, Vol. 74, No. 3, Mar., 1996.

MARCUSE, Peter "Enclaves, sim; Guetos não: a segregação e o estado". Espaço \& Debates 45. 2004

MARQUES, Eduardo César. "Elementos conceituais da segregação, da pobreza urbana e da ação do Estado". In: MARQUES, E. C. \& TORRES, H. G. (Orgs.) São Paulo: segregação, pobreza e desigualdades. São Paulo: Editora Senac, 2005a.

MARQUES, Eduardo César. "Espaço e grupos sociais na virada do século XXI". In: MARQUES, E. C. \& TORRES, H. G. (Orgs.) São Paulo: segregação, pobreza e desigualdades. São Paulo: Editora Senac, 2005b.

MARQUES, Eduardo César; BICHIR, Renata Mirandola. "Investimentos Públicos, infra-estrutura urbana e produção da periferia em São Paulo". Espaço e Debates 42. 2001 .

MARQUES, Eduardo; SCALON, Celi. “A dinâmica dos grupos sociais em São Paulo na década de 1990". Apresentado na XXXII Encontro Anual da ANPOCS (Associação Nacional de Pós-Graduração e Pesquisa em Ciências Sociais), 2008. 
MARQUES, Eduardo César; TORRES, Haroldo Gama (Orgs.) São Paulo: segregação, pobreza e desigualdades. São Paulo: Editora Senac, 2005.

MARQUES, Eduardo; SCALON, Celi; OLIVEIRA, Maria Aparecida “Comparando estruturas sociais no Rio de Janeiro e em São Paulo.” Associação Nacional de PósGraduação e Pesquisa em Ciências Sociais (ANPOCS), 2007.

MASSEY, Douglas. "Social Class and Ethnic Segregation: A Reconsideration of Methods and Conclusions," American Sociological Review 46:641-50, 1981.

MASSEY, Douglas; DENTON, Nancy. "Trends in the Residential Segregation of Blacks, Hispanics, and Asians: 1970-1980” American Sociological Review, Vol.52, №. 6, 1987.

MASSEY, Douglas; DENTON, Nancy. "The Dimensions of Residential Segregation." Social Forces 67:281-315. 1988.

MASSEY, Douglas; DENTON, Nancy. American Apartheid: Segregation and the Making of the Underclass. Cambridge, MA: Harvard Univ. Press. 1993.

MERTON, Robert King. Sociologia: teoria e estrutura. São Paulo: Mestre Jou. 1970.

NASCIMENTO, Érica Peçanha. Literatura Marginal: os escritores da periferia entram em cena. Dissertação de Mestrado. PPGAS-FFLCH-USP. 2006.

NOGUEIRA, Oracy. Preconceito de marca. As relações raciais em Itapetininga. Apresentação e edição de Maria Laura Viveiros de Castro Cavalcanti. São Paulo, Edusp. (1998 [1955])

NOGUEIRA, Oracy. "Preconceito racial de marca e preconceito racial de origem sugestão de um quadro de referência para a interpretação do material sobre relações raciais no Brasil", Tempo Social: Revista de Sociologia da USP. Vol. 19 (1) (2006 [1954]) 
OLIVEIRA, Ney dos Santos. "Favelas and Ghettos: Race and Class in Rio de Janeiro and New York City”. Latin American Perspectives, Vol. 23, No. 4, 1996.

PIERSON, Donald. Brancos e pretos na Bahia. São Paulo: Editora Nacional (Brasiliana; vol. 241) (1971 [1942])

PIERUCCI, Antônio Flávio. "A direita mora do outro lado da cidade". Revista Brasileira de Ciências Sociais No. 10. Vol. 4, junho de 1989.

PINTO, L. A. Costa. O Negro no rio de Janeiro: relações de raça numa sociedade em mudança. Rio de Janeiro, Editora da UFRJ. (1998 [1953])

PRÉTECEILLE, Edmond. "A construção social da segregação urbana: convergências e divergências". Espaço \& Debates 45. 2004.

QADDER, Mohamed. "Segregação étnica em uma cidade multicultural - Toronto, Canadá" Espaço \& Debates 45. 2004.

RIBEIRO, Luiz Cesar de Queiroz. "Status, Cor e Desigualdades Sócio-Espaciais na Metrópole do Rio de Janeiro". In: XII Encontro da ANPUR. Belém: 2007.

RIOS NETO, Eduardo. "Desigualdade Raciais nas Condições Habitacionais da População Urbana”. CEDEPLAR/UFMG. Mimeo. 2005.

ROLNIK, Raquel. "Território Negros nas Cidades Brasileiras (Etnicidade e Cidade em São Paulo e no Rio de Janeiro)”. Estudos Afro-Asiáticos No. 19, pp 29-41. 1989.

SABATINI, Francisca; SIERRALTA, Carlos. "Medição da segregação residencial: meandros teóricos e metodológicos e especificidade latino-americana." In: CUNHA, José Marcos Pinto da (org.). Novas metrópoles paulistas: população, vulnerabilidade e segregação. Campinas, SP : UNICAMP/NEPO, 2006. 
SABATINI, Francisco; CÁCERES, Gonzalo; CERDA, Jorge 2004. "Segregação residencial nas principais cidades chilenas: tendências das três últimas décadas e possíveis cursos de ação”. Espaço e Debates 45. 2004.

SANTOS, José Alcides Figueiredo. "Efeitos de Classe na Desigualdade Racial no Brasil”. DADOS - Revista de Ciências Sociais, Rio de Janeiro, Vol. 48, no 1, 2005.

SILVA, Nelson do Valle. “A Posição Social das Ocupações”. Mimeo. 1973.

SILVA, Maria Nilza da. "Nem para todos é a cidade: segregação urbana e racial em São Paulo”. Doutorado em Ciências Sociais. PUC-SP. 2004.

SIMÕES, Rodrigo. Métodos De Análise Regional E Urbana: Diagnóstico Aplicado Ao Planejamento. Texto para Discussão -CEDEPLAR n.259, Maio, 2005

SOARES, Reinaldo da Silva. Negros de classe média em São Paulo: estilo de vida e identidade negra. Tese de Doutorado em Antropologia Social. São Paulo: FFLCH-USP. 2004.

TELLES, Edward. "Cor da Pele e Segregação Residencial no Brasil". Estudos AfroAsiáticos No. 24, pp. 5-22. 1993.

TELLES, Edward. "Race, Class and Space in Brazilian Cities" International Journal of Urban and Regional Research Nº. 19. pp. 295-406. 1995.

TELLES, Edward. "Identidade Racial, Contexto Urbano e Mobilização Política" AfroÁsia 17. 1996.

TELLES, Edward. Racismo à Brasileira. Uma Nova Perspectiva Sociológica. Rio de Janeiro. Relume-Dumará / Fundação Ford. 2003.

TORRES, Haroldo da Gama. "Segregação Residencial e Políticas Públicas: São Paulo na década de 1990". Revista Brasileira de Ciências Sociais Vol. 19. 54 fev/2004a. 
TORRES, Haroldo da Gama. "Debate: A pesquisa sobre segregação: conceitos, métodos e medições". Espaço e Debates 45. $2004 \mathrm{~b}$.

TORRES, Haroldo da Gama. "Medindo a segregação". In: MARQUES, E. C. \& TORRES, H. G. (Orgs.) São Paulo: segregação, pobreza e desigualdades. São Paulo: Editora Senac, 2005.

TORRES, Haroldo da Gama. "A Fronteira Paulistana". In: MARQUES, E. C. \& TORRES, H. G. (Orgs.) São Paulo: segregação, pobreza e desigualdades. São Paulo: Editora Senac, 2005b.

TORRES, Haroldo da Gama; MARQUES, Eduardo César; FERREIRA, Maria Paula; BITAR, Sandra. "Pobreza e Espaço: padrões de segregação em São Paulo". Estudos Avançados 17 (47) 2003.

VARGAS, João H. Costa. "Apartheid brasileiro: raça e segregação residencial no Rio de Janeiro.” Revista de Antropologia Vol. 48 N. 1. São Paulo: USP. 2005.

VELHO, Gilberto. A Utopia Urbana: um estudo de antropologia social. Rio de Janeiro: Zahar Editora. 1973.

VILLAÇA, Flávio. "Os Efeitos do Espaço sobre o Social” in SOUZA, Maria Adélia et al (orgs) Metrópole e organização: conhecendo a cidade de São Paulo, CEDESP, São Paulo. 1999.

VILLAÇA, Flávio. "Debate: A pesquisa sobre segregação: conceitos, métodos e medições”. Espaço e Debates 45. 2004.

WACQUANT, Loic. "Estado e destino do gueto: Retraçando a linha de cor urbana na América pós-fordista”. Estudos Afro Asiáticos 26. 1994. 
WEBER, Max "A distribuição do poder dentro da comunidade: Classes, estamentos e partidos." Em: Economia e Sociedade: fundamentos da sociologia compreensiva. (Volume 2). Brasília / São Paulo: Editora UnB / Imprensa Oficial. 2004. 